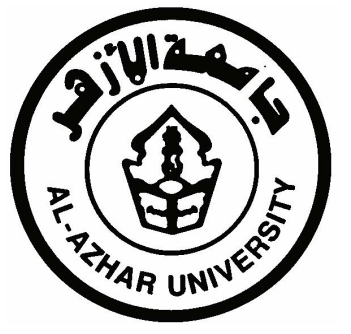

$$
\begin{aligned}
& \text { جامعست الأزهــــر } \\
& \text { كليــت أصــول الديـنـن } \\
& \text { والدعوة الإسلاميت بالمنوفيت }
\end{aligned}
$$

النداءات الإلهيــــــة في

$$
\text { القرآن الكريم }
$$

\title{
الركثرر
}

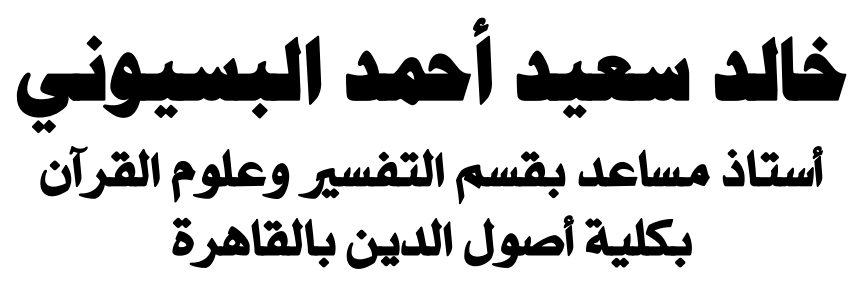





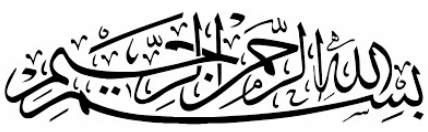

الحمد لله العلي القدير، السميع البصير، الذي لا تدركه الأبصار وهو يدرك

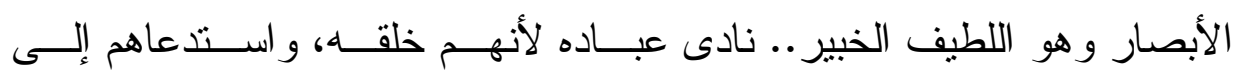
روضات طاعته لينالو ا رحمته، و عزته في الدنيا و الآخرة..

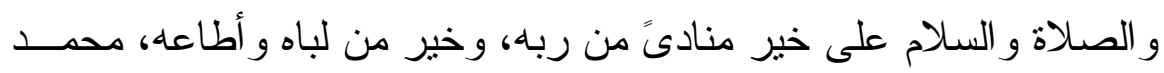

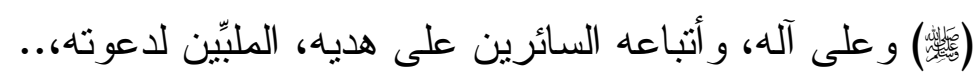

\section{ولعد66 6}

فمن المعلوم أنَّ النداء في القرآن الكريم صورةٌ من صورِ بـلاغته، ووجـــهُ

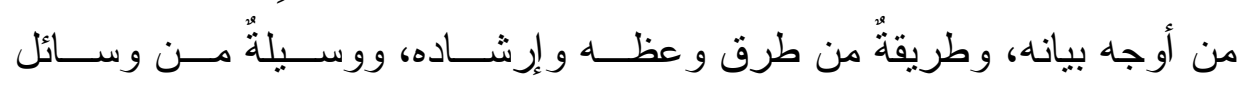

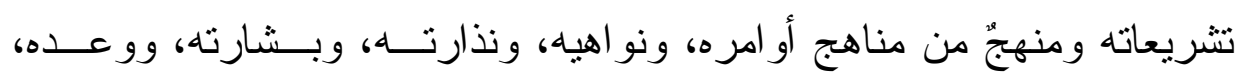
وو عيده.... الخ.

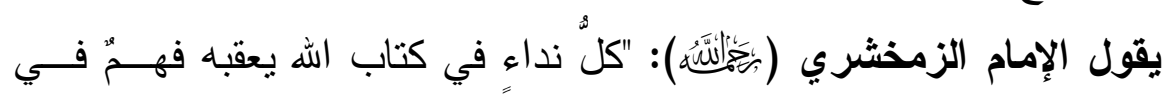

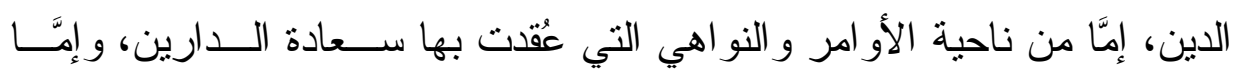

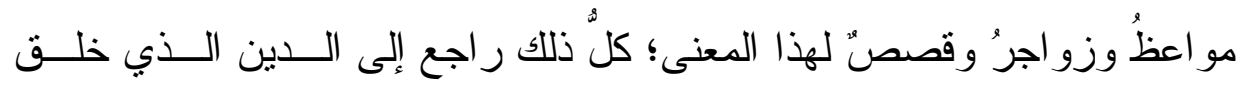

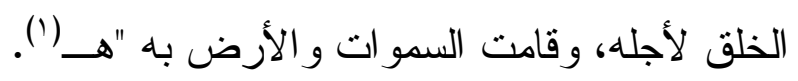

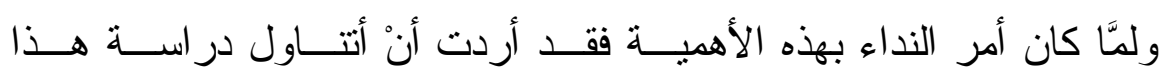
الموضوع، وجمع عناصره في هذا البحث المتو اضع مقتصر اً علــى النــداءات

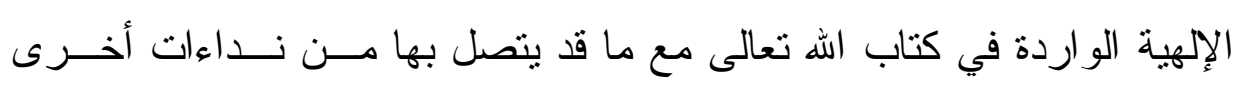

(1) ينظر : البرهان في علوم القرآن "النوع الخامس و الأربعون" r - بـ ب للإمام الزركثي. مكتبة دار التزراث - القاهرة. 


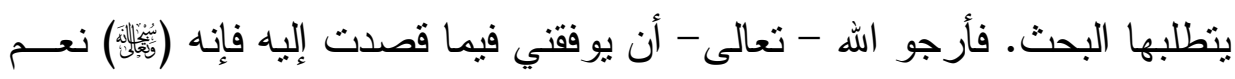

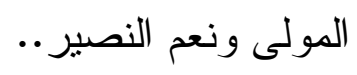

وقد قسمت هذا البحث إلى فصلين:

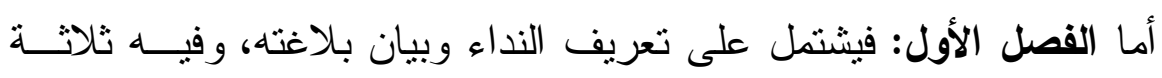

$$
\text { مباحث: }
$$

المبحث الثاني: بيان سرِ مجيء القرآن الكريم بأداة النداء "يا"، وسرّ حذفها في بعض المو اضع من القرآن الكريم.

المبحث الثالث: بيان معنى "أبي "وحكمة ذكره في النداء، وكذا "ها" التتبيـــهـ وحكمتها.

و أما الفصل الثاني: فيشتمل على بيان أنواع النداء فــي القــرآن الكـــيم

ومغز اه.

$$
\text { وفيه مبحثان: }
$$

المبحث الأول: النداء التكويني.

المبحث الثاني: التداء التكليفي. وفيه خمسة مطالب:

$$
\text { المطلب الأول: نداء الناس جميعاً. }
$$$$
\text { المطلب الثاني: نداء الشعوب. }
$$$$
\text { المطلب الثالث: نداء الطو ائف. ناء. }
$$

المطلب الر ابع: نداء الجماعة المحدودة العدد. المطلب الخامس: نداء الأفر اد أو الأشخاص.

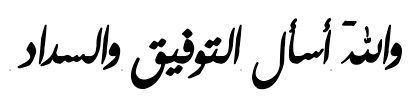

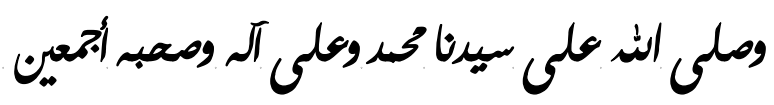




\section{الفصل الأول \\ تعريف النداء وبيان بلاغته}

بادئ ذي بدء فإنَّ مما استقرَّ للى العلماء و الباحثين، أنَّ التعريفات اللغويـــة و الاصطلاحية لأيِّ موضوع ذو أهمية كبرى، إذ إنه في جميع الأحسـو ال يعـين

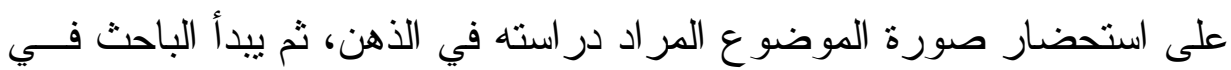
موضوعه وقد حدد، أو بمعنى آخر وقد فرغ من التعريفات المناسبة له. وفي هذا الفصل من تعريف النداء وبيان بلاغته سنجد أن لتعريف النـــداء صلة مباشرة في استخر اج كل المعاني البلاغية التي يشتمل عليها النــداء فــي لـي القر آن الكريم.

فمثلاً: اختيار حرف النداء (يا) ليكون هو حرف النداء الوحيد الـذي أنـى عليه النداء في القرآن له مغز اه البلاغي، ودلالته على المر اد منه سواء أمراً أو أو نهياً، أو غير ذلك. الته. وكذلك مجيء (أيْ) و (هاء) التتبيه في النداء، وكذلك عندما يحـذف هــذا النداء.. كل ذللك مما له علاقة مباشرة بتعريف النداء، و أدو اته. وفيما يلي تفصيل ذلك من خلا المباحث التالية. 
الدكتور / خالد سعيد أحمد البسيوني

$-7-$ 


\section{المبحث الأول}

\section{تعريف النداء وأدواته}

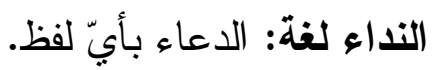

و اصطلاحاً: طلب الإقبال بحرف نائب مناب "أدعو "لفظأ أو تقديراً (1).

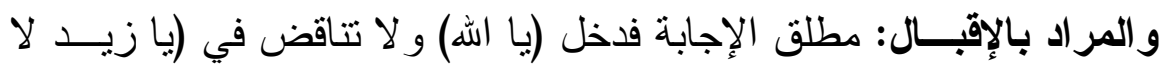

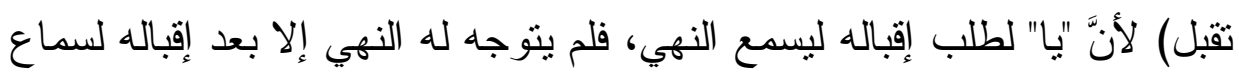
النهي.

و لا ينادى في الحقيقة إلا المميّز لأنه الذي تتأنى إجابته و أما غيره كـــــــا

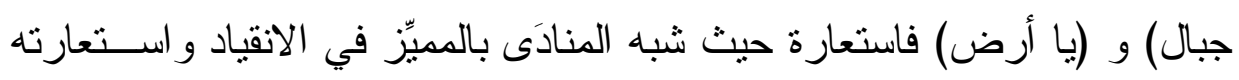

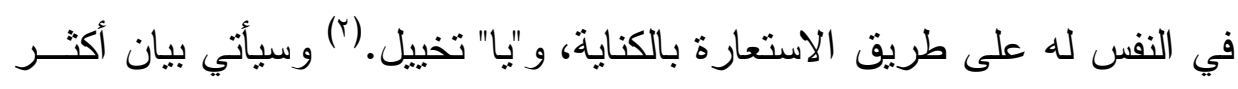

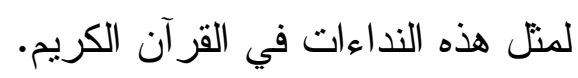

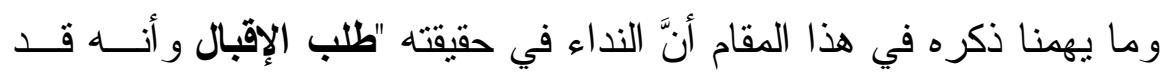

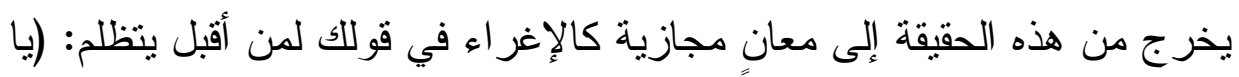

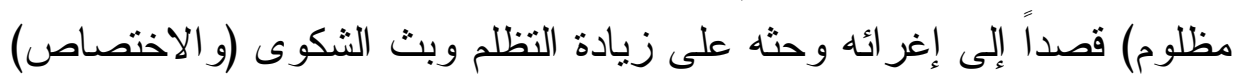

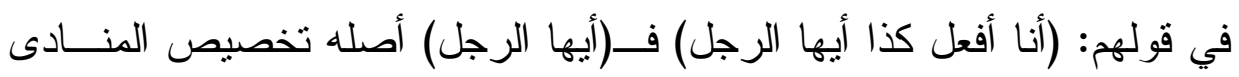

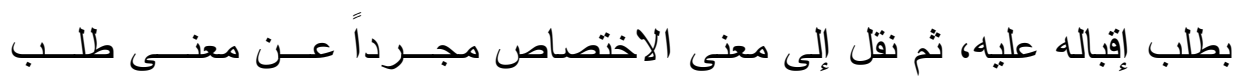

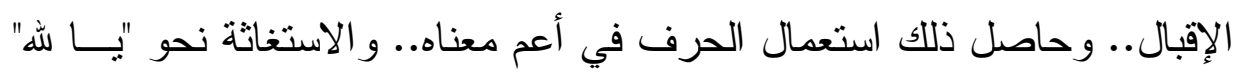

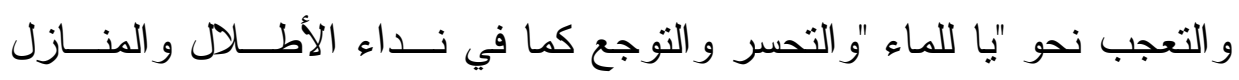

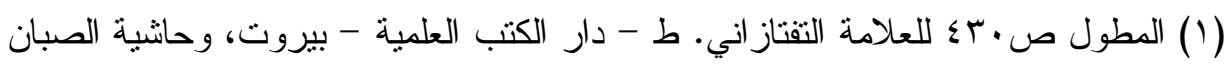

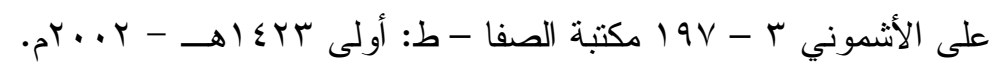

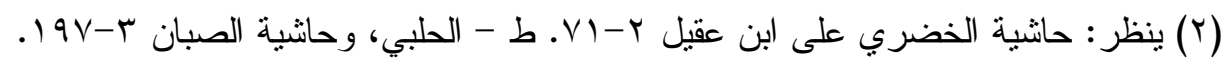


و المطايا وما أثنبه ذلك مما يشعر بأنّ هذا النداء يحقق مرجوّاً أو مأمو لاً أو يدفع

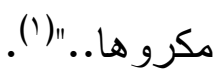

أمَّا أدو ات النّدّاء فهي كما ذكر ها ابنُ مالك في ألفيته:

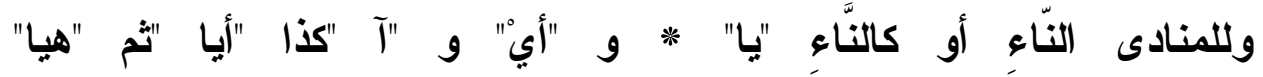

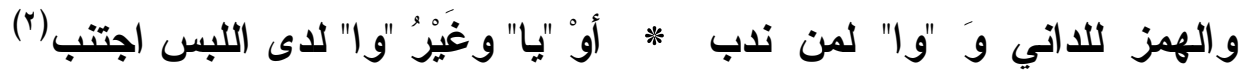
تلك هي أدوات النداء يتفاوت استخدامها حسب بُعْد أو قرب المنــادَى مــن المنادي لكن ما له التمبز من هذه الحروف هو "با" فهي الأفثـى فــي العربيـــة،

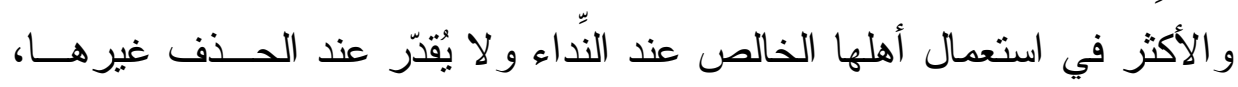

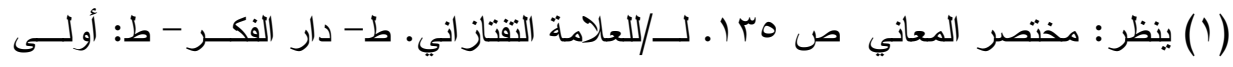

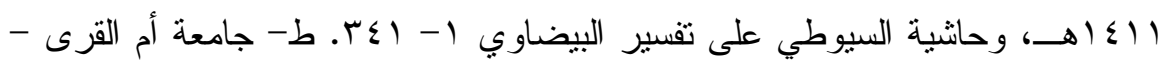

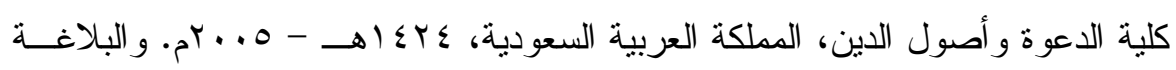

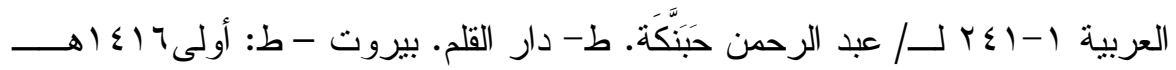
.) $999-$

(Y) يقول ابن عقيل في شرح هذين البيتين من الألفية: "المعنى: لا يخلو المنادى من أن يكون

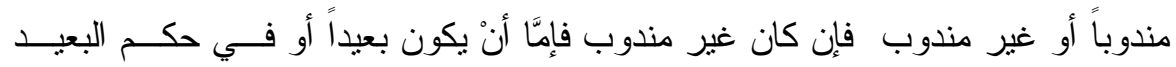

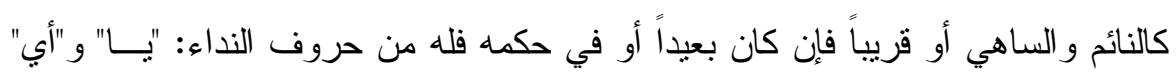

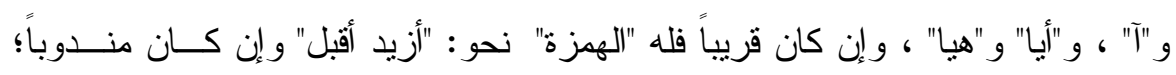

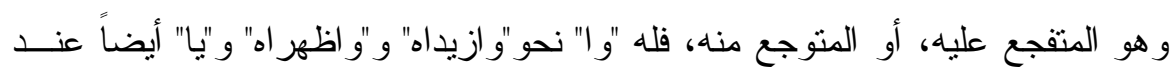

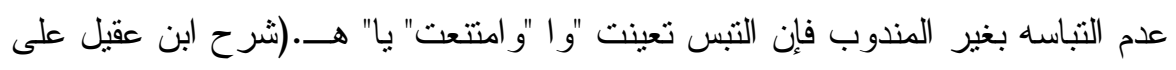

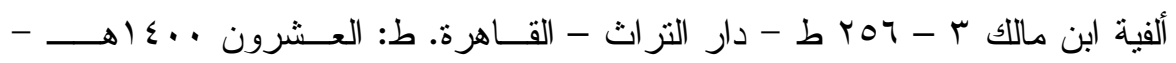
. 191. 


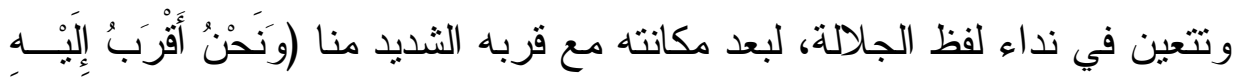

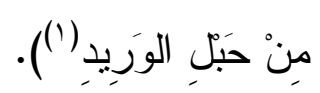

وتتعين أيضاً في باب "الاستغاثة" نحو: يا لله. كما تتعين فــي نــداء أيهـــا

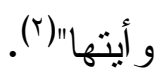

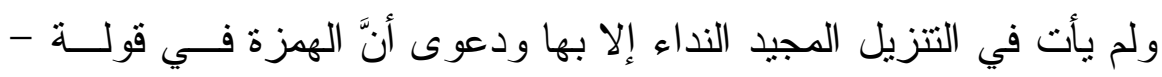

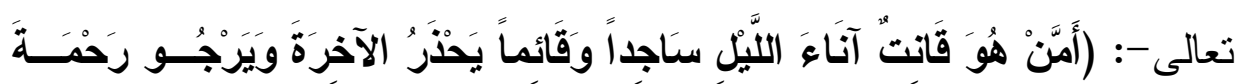

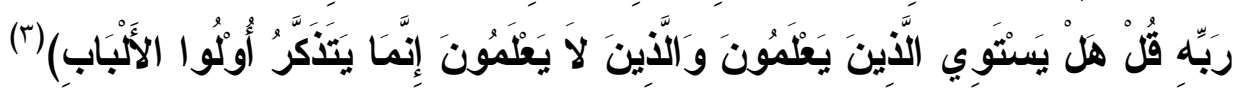

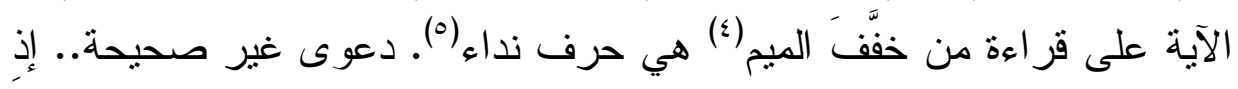

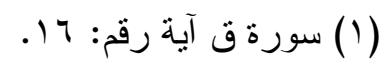

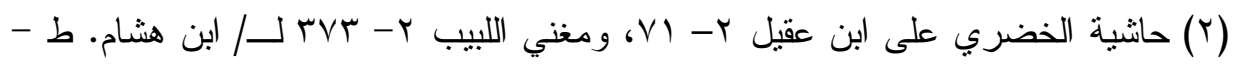

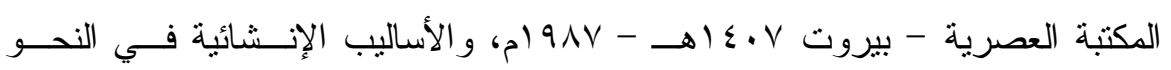

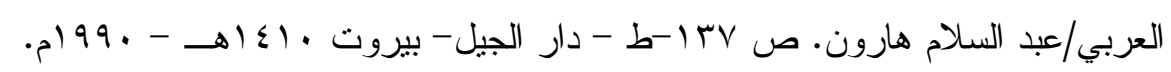

$$
\text { (؟) (ب) سورة الزمر آية رقم: } 9 .
$$

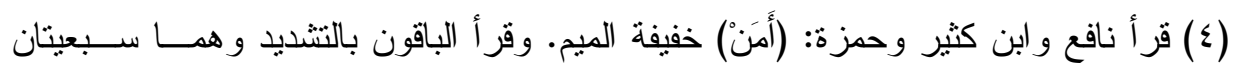

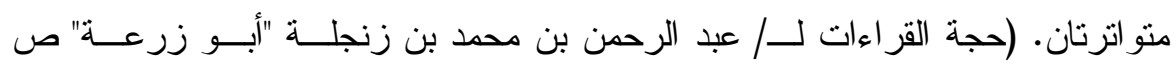

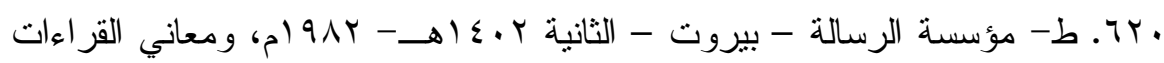

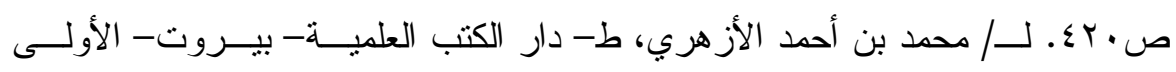
. 999 - 99 ا

(0) حمل الهمزة في هذه القر اءة على أنَّها حرف نداء هو قول الفراء حيث يقول: مــن قــر أ

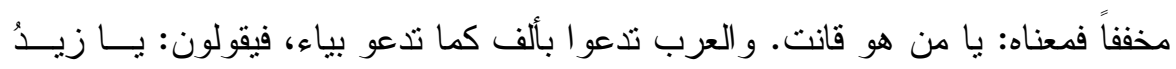

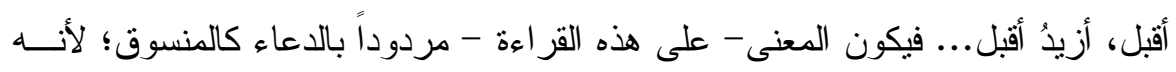

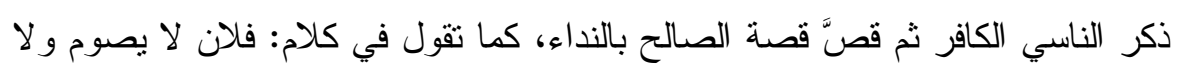

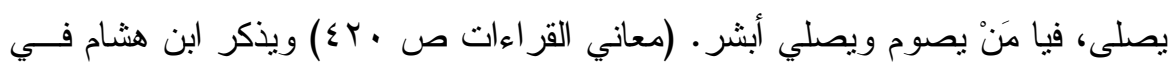

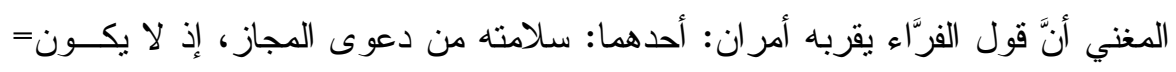


الهمزة في الآية هي همزة الاستقهام المحذوفة المعادل. و التقدير : أهَنْ هو قانــت

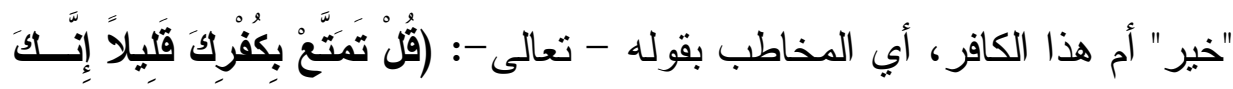
مننْ أَصْحَابِ النَّارِ)(') فحذف شيئَان: معادل الهمزة و الخبر (؟).

=الاستفهام منه - تعالى - على حقيقته. ثانيهما: سلامته من دعوى كثرة الحذف. لكـن يبعد هذا القول - كما ذكر ابن هثام أيضاً - أنه ليس في التنزيل نداء بغير "يا".(مغنـي دئهي

$$
\text { 1- اللبيب (-س (1). }
$$

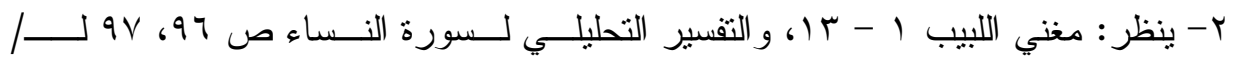

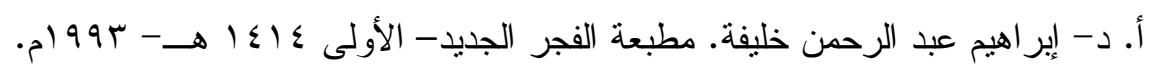


المبحث الثاني

\section{بيان سرّ هجيء النداء في القرآن الكريم بـ (يا)، وسرّ هذفها في بعض المواضع من القرآن الكريم}

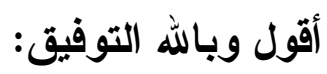

يتبين سر" مجيء النداء في القرآن الكريم بــ(يا) دون بقية أدوات النداء من

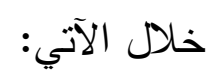

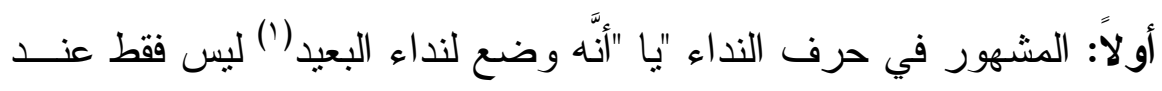
النحويين - كما سبق ذكره في بيت ابن مالك: وللمنادى الناء أو كالنــاء "يـا".. الخ....

بل و المشهور أيضاً عند أكثر البلاغيين(r) وجمهور المفسرين كذلك(r).

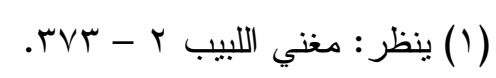

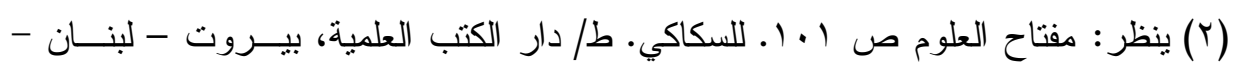

$$
\text { ط:Y }
$$

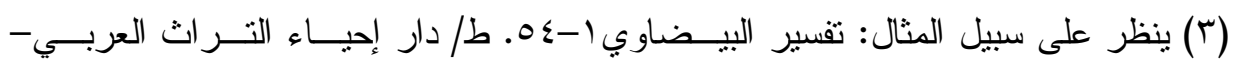

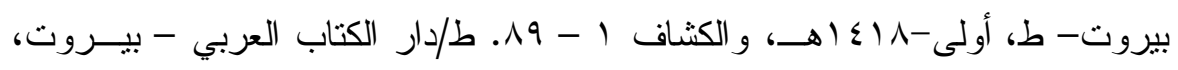

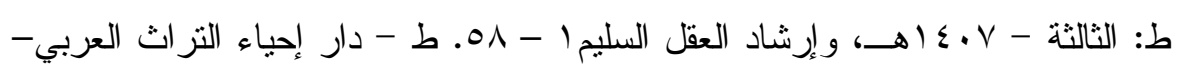

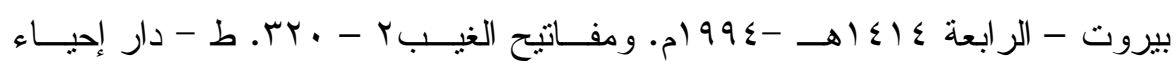

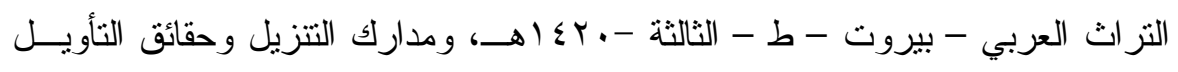

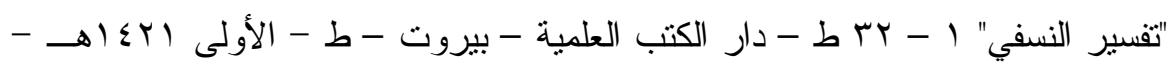

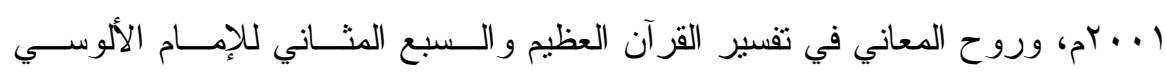

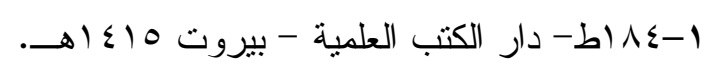




\section{وقيل: "يا "تخخل في كلِّ نداء.(1)}

ويذهب الصبّان في حاثيته على الأشموني إلى أنَّ هذا الحرف وضع لنداء

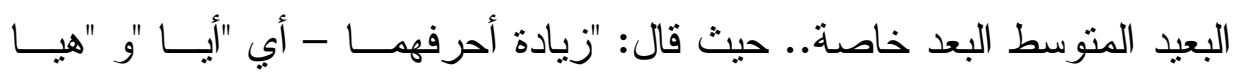

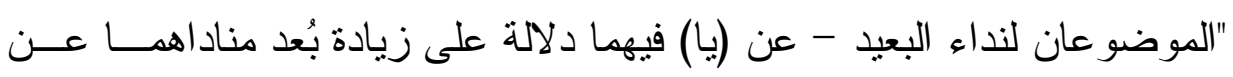

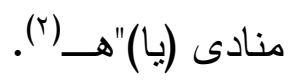

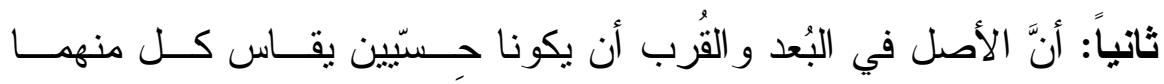
بالمسافة المكانية بين شيئين، لكن ملاحظة ذلك في أكثر نداءات القر آن الكــريم لا تتم إلاَّ على وجوه مجازية حسبما يقتضيه المقام.

فالنداءات التي بين الله - تعالى - وخلقه لا يتصور فيها المـسـافة الحـسية

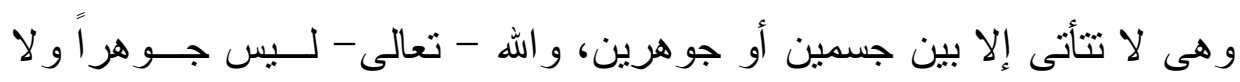
عرضاً، و لا جسماً، و لا غير ذلك من سمات الخلق. كما أنَّ النداءات التي بـينين الخلق بعضهم البعض - أي في كتاب الله - تعالى - لا يتصور فـي معظمهــا

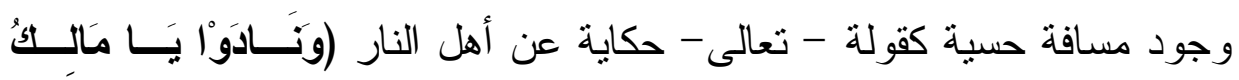

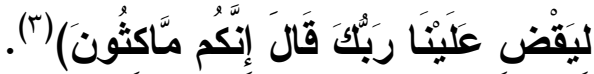

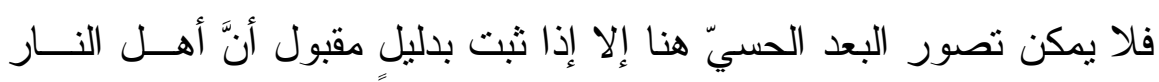

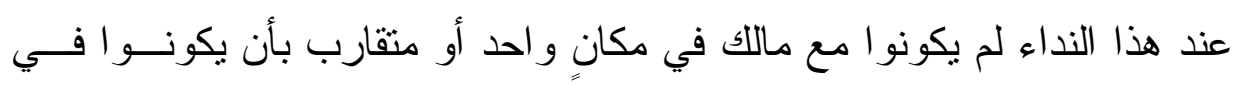

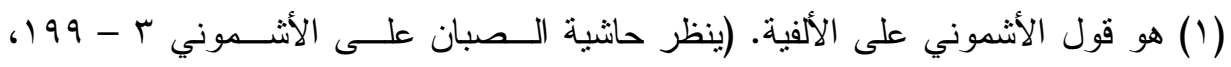

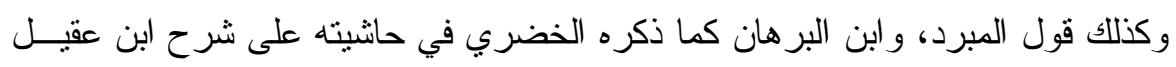

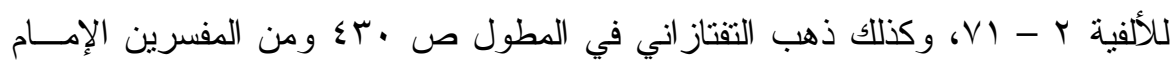

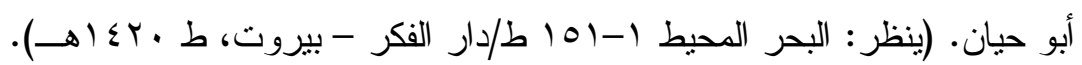

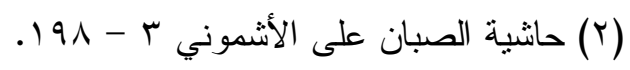

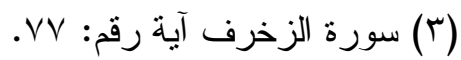




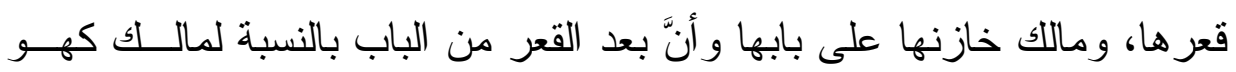

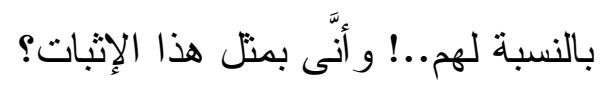

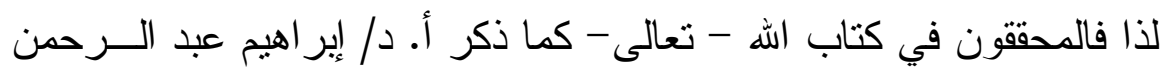

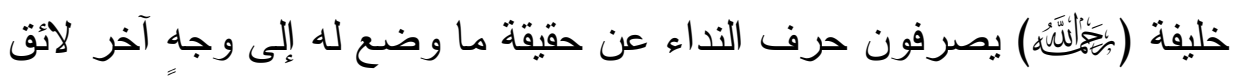

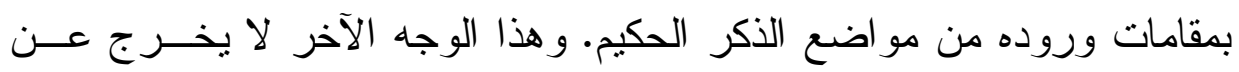
أمرين قد يجتمعان وقد ينفرد أحدهما. أحدهما: تنزيل البعد المعنوي منزلة البعد الحسي إمَّا: للإثـــعار بتعــاظم الفرق بين المنادي و المنادَى.

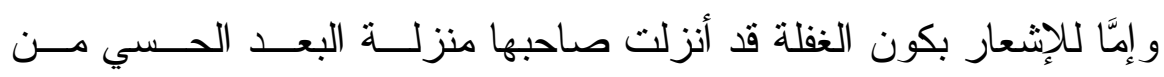

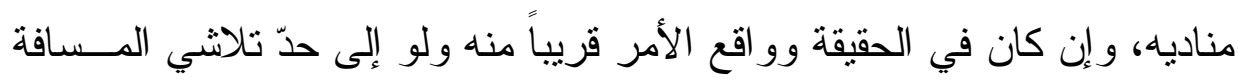
بينهما بالكلية.

أمّا ما يكون فيه هذا التنزيل للإثثعار بتعاظم الفرق بين المنادِي والمنادَى

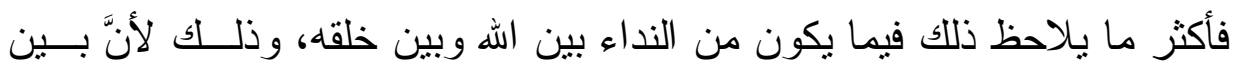

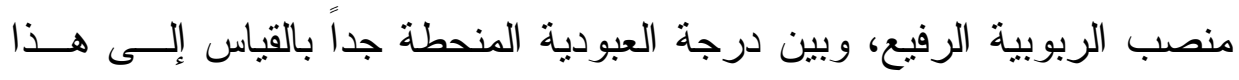
المنصب.. من البون الثاسع و الفرق الجسيم الذي لا حدّ لتعاظمه وكماله من كل وجه ما لا يتصور في الخيال فضلاً عن الحقيقة أبعد منه.. فمهما يكن من شأن لأن

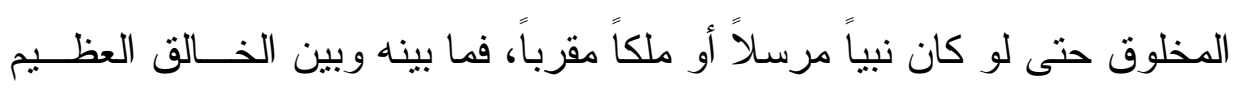

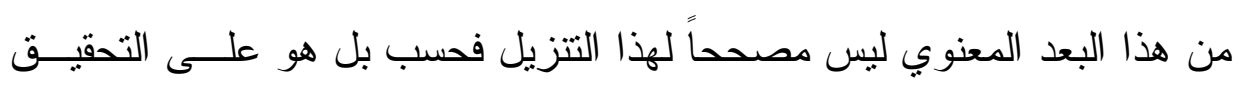
أعظم من أن يحيط بمداه علمُ أو يدركه فهمٌ. ولو لا ضرورة توقف أفهامنا و اضطر ارنا في التخاطب إلى العبادات ولــــ

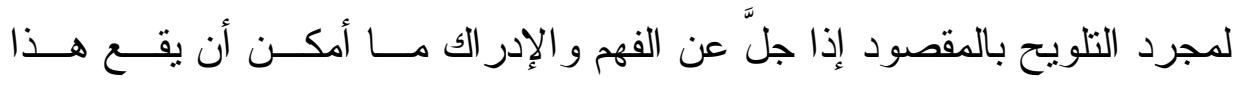
المقصود هنا تحت عبارة أصلاً. 
وأمَّا ما يكون فيه هذا التنزيل للإشعار بكون الغقلة قد أبعـدت صــاحبها عمن يناديه و إن كان قريباً منه في الواقع ونفس الأمر .. فبتجلي ذلك أبلغ ما يتجلى في نداء الله - تعالى - للكافرين من عباده فــإنَّهم بكفر هم و غفلتهم من معرفة ربهم وما نصبه لهم من بينات على هذه المعرفة من آيات الأنفس و الآفاق قد أبعدو أنفسهم عن ساحة رحمته و أهلية خطابــهـ و وغيـر ذلك مَِّّا يجعلهم في غاية البعد عن المنادي - تعالى -.

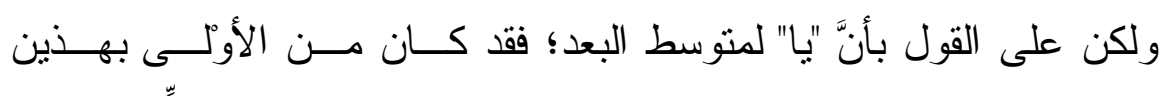

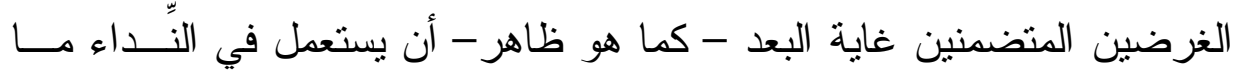

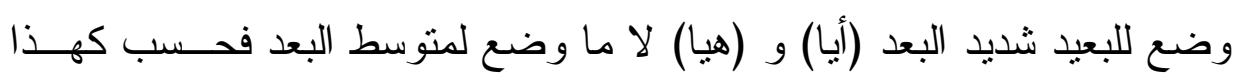
الحرف (يا) الذي لم يأت في القرآن غيره. ويجاب على ذلك بأنَّ هذا الحرف "يا" أوثر عن أخويه (أيا) و (هيــا) مـــدًاً للخلق في بعض أسباب الأمل و الرجاء كرماً منه - تعالى - حتى لا تتقطع بهـــ الهـ أسباب الأمل في نيل رحمته وقربه فيقضي عليهم اليأسُ التام من تقارب النـسبة

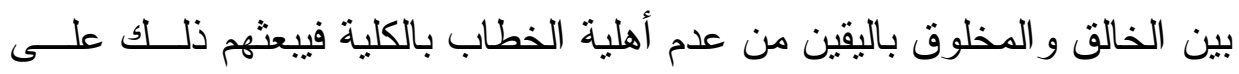
الإعر اض عما في خطابات الثار ع من هدى ونور .."هـ ('). إذاً فالمجاز في النداء بـ (يا) في هذا الوجه: إمَّا للإثتعار بتعاظم الفرق بين المنادي و المنادَى.

و إمَّا للإشعار بكون الغفلة قد أبعدت صـاحبها عمن يناديه و إن كــان قريبـاً منه في الو اقع و المناسب في هذا الوجه هو الإتيان بــ "يا" و التي هي لمتوســـ البعد لدى البعض - مداً للخلق في أسباب الأمل..

(1) التفسير التحليلي لسورة النساء ص 91 - r • ( ـ بتصرف. 
ويضاف إلى ذلك أنه لا بد أنْ نُلاحظ أنَّ الله - تعالى - عندما بنادي علـى

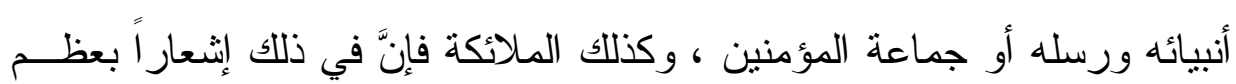

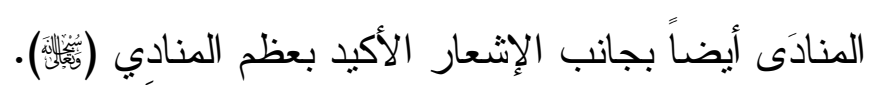

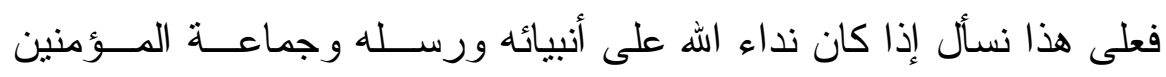

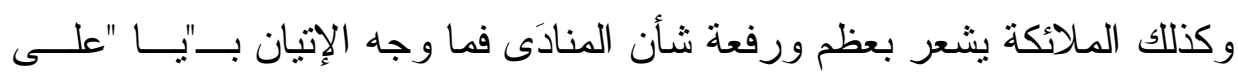

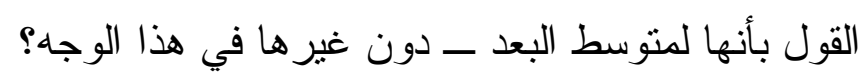

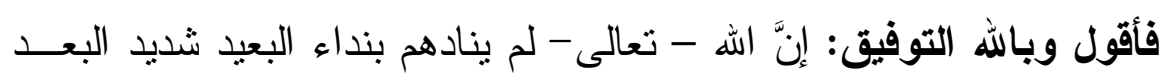
لأنهم قريبون إلى ربِّ العالمين بالطَّاعة و الإنابة.

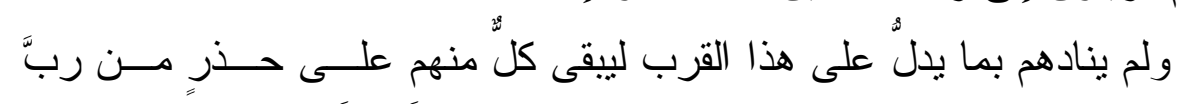

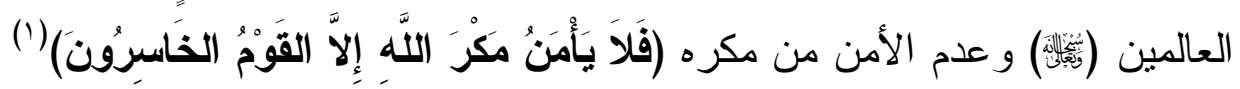

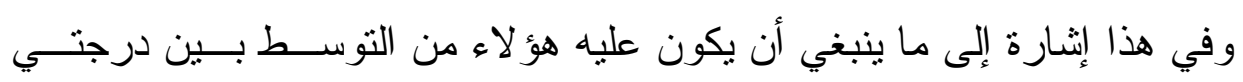
الخوف و الرخاء. و الله أعلم

أمَّا الوجه الثاني من وجهي خروج النداء من الحقيقة إلى المجــاز فــالأمرٍ آخر يليق به حسب المقام وهو : "إظهار المنادِي الاهتمام بالأمر الأي ينادي من أجله..

وذلك أنَّ العادة المضطردة قد جرت بأنه لا يحسن أن تتادي بعيــداً عنـــ، وبحيث تكلفه المشقة في قطع المسافة الحسيّة الطويلة إليك إلا إذا كان ما تدعوه له أمر اً مهماً جدير اً أن تحتمل من أجله المشقة في قطع منل هذه المسافة..

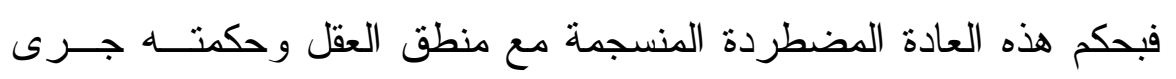
الكثير" من نداءات الذكر الحكيم.. كيف لا، ونداؤه - تعالى - على خلقه بأو امره ونو اهيه يعدُّ من الأهمية بمكان إذْ غاية كل منهما إصلاح الفرد و المجتمع.

$$
\text { (1) سورة الأعر اف آية رقم: } 99 .
$$


ويتجلى أيضاً في هذا الوجه حكمةُ النداء بـــ "يا" إذا ما لوحظ وضعه للبعيد

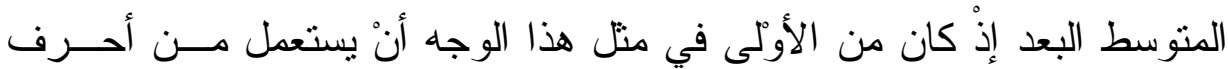
النداء ما وضع لثديد البعد لا لمتوسطه فحسب ليناسب الاهتمام بالأمر المنادَى،

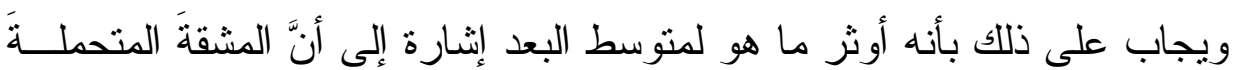

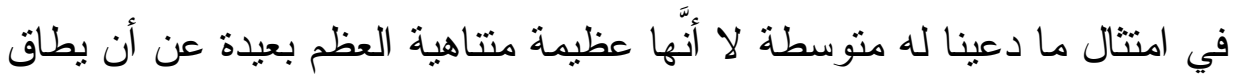
احتمالها حسبما كان يمكن أن يفيده ما هو موضو ع لثدة البعد..

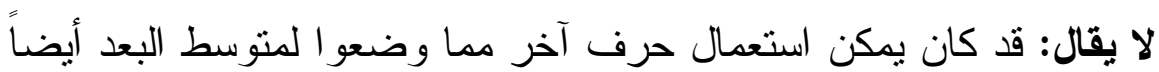
كــــ"آ" أو "أي" ليفيد المعنى المشار إليه...!

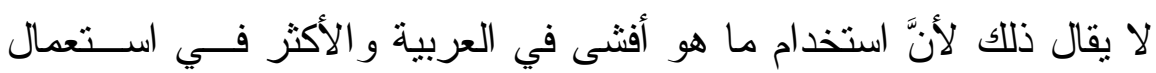
أهلها عند النداء أولى مما هو دونه في ذلك.

فبهذا كله يتبين أنَّ القرآن حين قصَرَ الاستعمال على هذا الحرف "يا "فـي تهي جميع نداءاته قد جرى على ما هو الأوفق بالحكمة، و الأجزل في البلاغة.."(() ونستخلص مما سبق:

أولاً: على القول بأنَّ "يا" لنداء البعيد فإنَّ نداء القريب بها إمَّا لعلــــو مرتبــــة المنادي. و إمَّا لتنزيل غفلة السامع وسوء فهمه منزلة بعده.

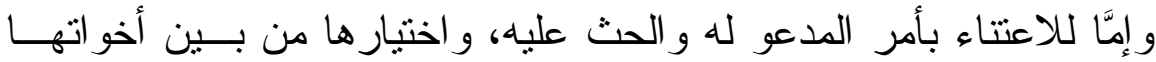
الدالة على البعد حينئذ كـــأيا" و "هيا" إنما هو لسهولة النطق بها وكثرتها على الألسنة حتى ليُظن أنْ ليس للنداء أداة إلا هي.

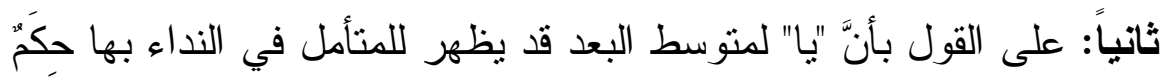
و أسر ارٌ يتجلى من خلالها وجهُ من وجُوه إعجاز كتاب الله - تعالى - هذا إذا لم ننظر إلى شيو عها وسهولة النطق بها، و إلا فتلك علة كافية لمجيء القرآن بهــا. 
فسمة القر آن الكريم هو التيسير وسلاسة التعبير كما قال - تعالىى -: (ولَقَدَ يَسَّنَّا

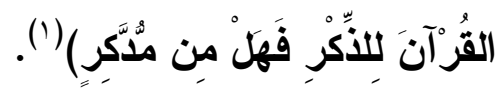
هذا عن سرّ اختيار "يا" في نداءات القر آن الكريم.

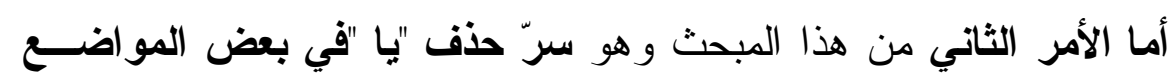

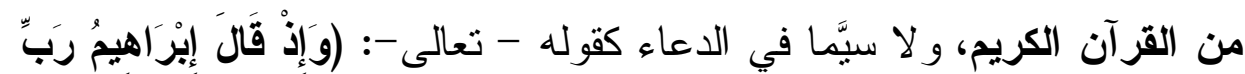

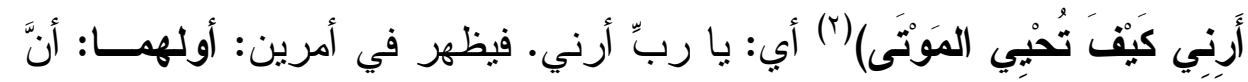
النّداء يتشرب معنى الأمر لأنك إذا قلت: يا زيد، فمعناه: أدعوك يا زيد، فحذفت "يا" من نداء الرب ليزول معنى الأمر ، ويتمض للتعظيم و الإجلال (r).

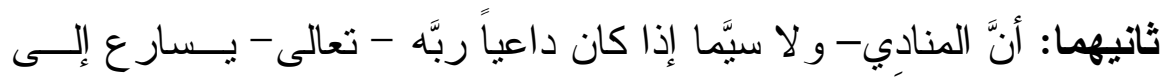
الاشتغال بذكر المنادَى بحيث لا يشغله عن هذا الذكر شيء.

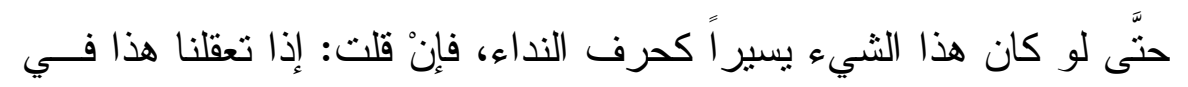

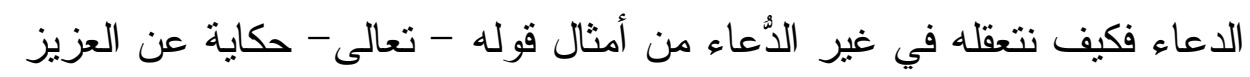

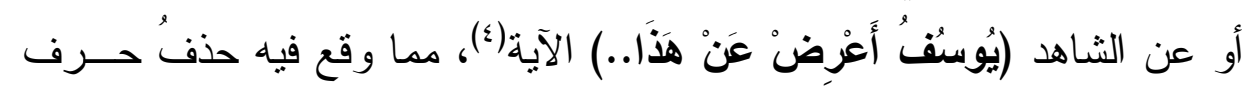
النداء وهو غير دعاء.

يجاب عليه بأنَّ الأمر في هذا هو بعينه ما قلناه في الدعاء، فإنَّ المنــاديفي نحو ما سبق من التمثيل به - بيّنُ التهالك مفرط الإقبال علــى المنــادَى لا لا

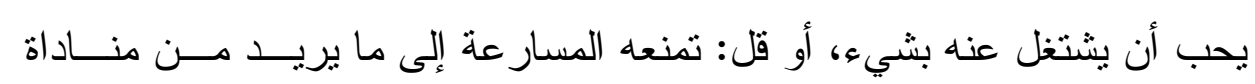

$$
\begin{aligned}
& \text { (1) سورة القمر آية رقم: VIV. }
\end{aligned}
$$

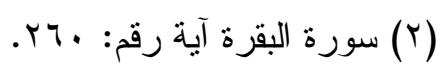

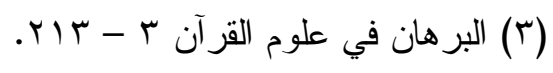

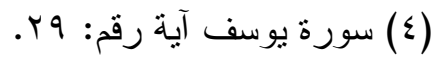




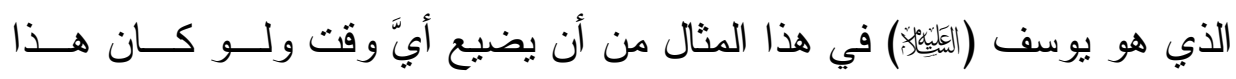
الوقت مجرد اللحظة التي يستغرقها حرف النداء لو ذكره.(')

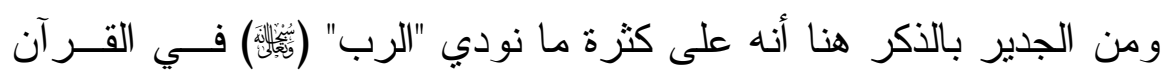
الكريم لم يعثر عليه مسبوقاً بحرف النداء إلا في موضعين:

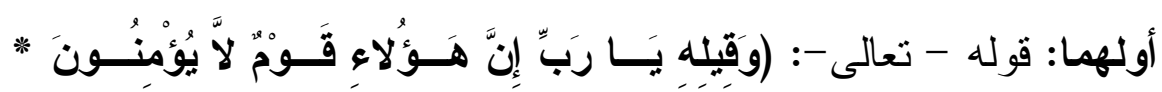

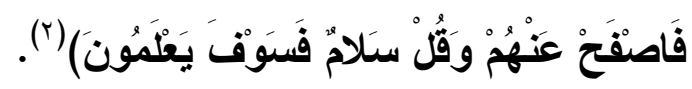

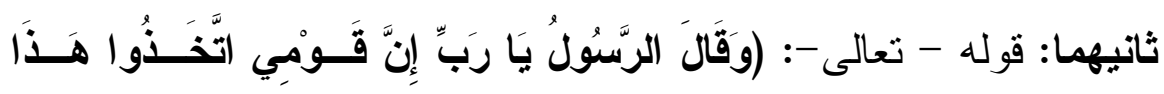

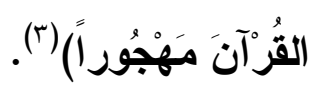
ولعلَّ مجيء حرف النداء في الأول ليعبر عن حالة نفسية ألمَّت بالرســول

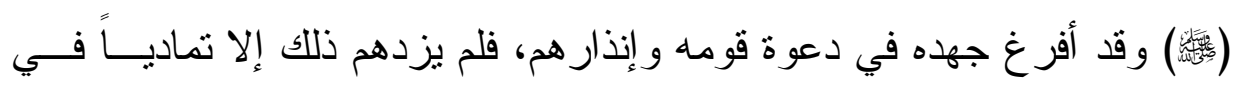

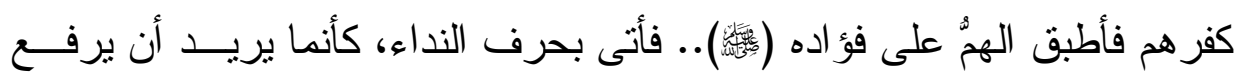
صوته زيادة في الضر اعة إلى الله، و استجلاب رضاه"(£).

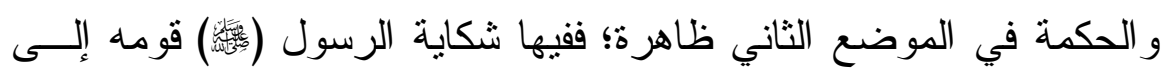

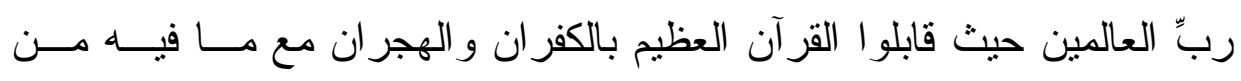

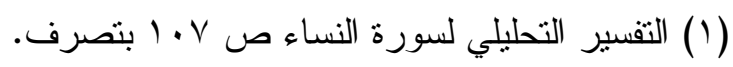

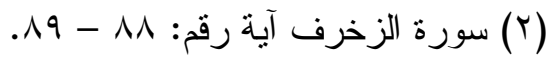

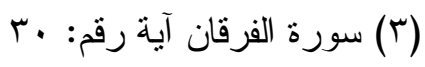

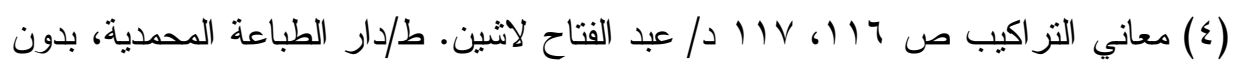

$$
\text { تاريخ بتصرف. }
$$




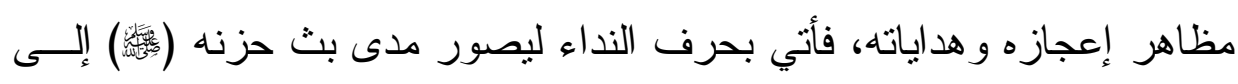
الله وشكو اه على قومه. (') وذكره تعالى لنداء نبيه (筷) في هذين الموضعين ممَّا يدلُ علي رفعة شأنه

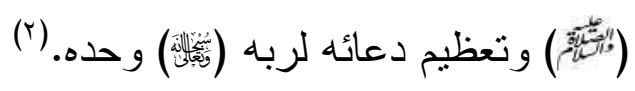

(1) قلت: في هذين الموضعين ردٌّ على صاحب المو افقات حيث ذكر أنه لم يأت في القـــر آن نداء من العباد إلى الله - تعالى - بحرف نداء ثابت بناء على أن حرف النداء للن للتنبيه في

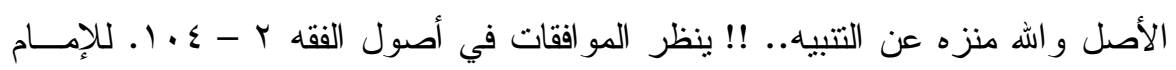

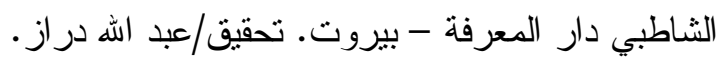

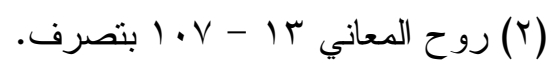




\section{الهبحث الثالث}

\section{بيان معنى "أي" ومكمة ذكره في النداي، وكذا "ها" التنبيه}

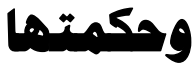

$$
\text { أما عن "أبي" وحكمة ذكره في النداء: }
$$

فلا شك أنَّ مجيء "أيْ" في النداء بــــا "يا "يزيده تأكيداً لما يقتضيه الــسياق

اللغوي أو سياق المقام (').

فـــ "أيث" عنصر لغوي ذو نأنير في اللفت والإيقاظ..

و "أَيّ" هذه - كما في كتب النحو (r)- اسم يأتي على خمسة أوجه:

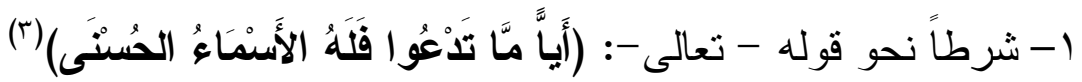

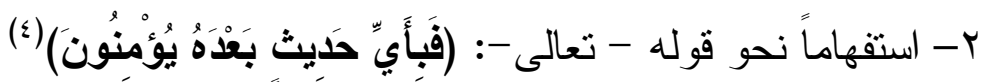

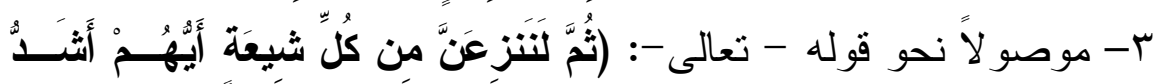

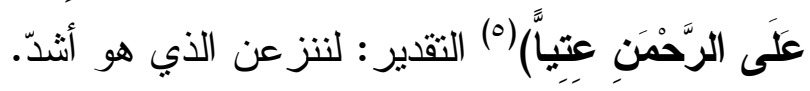

(1) السباق اللغوي هو : الكلمات و الجمل السابقة و اللاحقة للكلمة، و النصّّ الذي تـــرد فيـهـ..

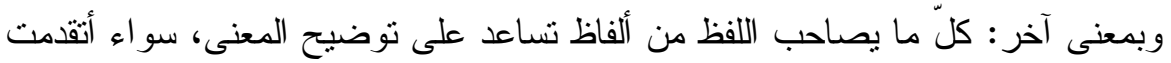

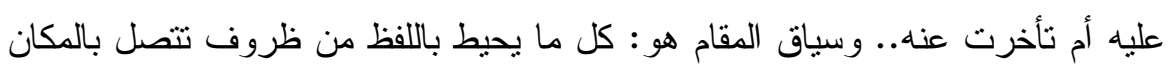

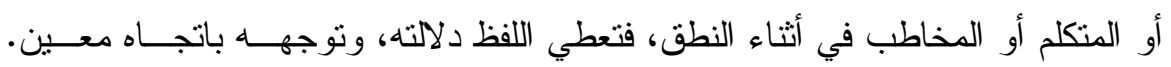

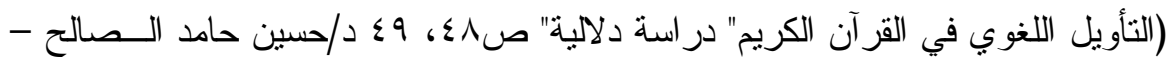

$$
\begin{aligned}
& \text { دار ابن حزم - صنعاء بدون. }
\end{aligned}
$$

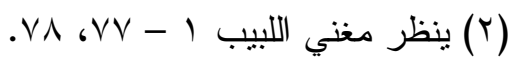

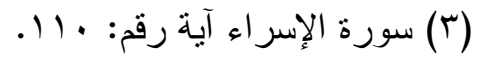

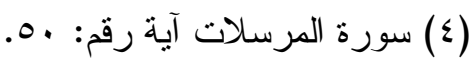

$$
\begin{aligned}
& \text { (0) سورة مريم آية رقم: } 79 .
\end{aligned}
$$


ع- أن تكون دالة على معنى الكمال، فتقع صفة للنكرة نحو "زيَدُ رجلْ أيُّ

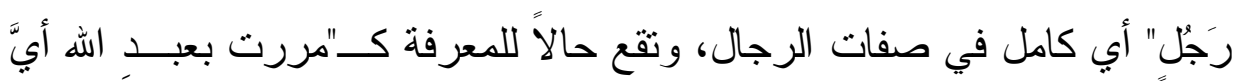
رجل.

ه- أن تكون وُصنَّةً إلى نداء ما فيه أل، نحو "يَا أيُهها الرجُل". و هذا هو الوجه الأخير الذي يههنا من استخدامات "أي"."

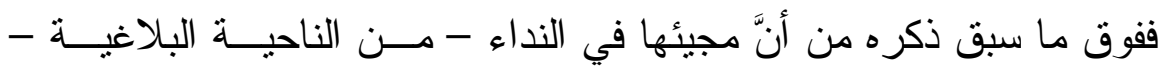

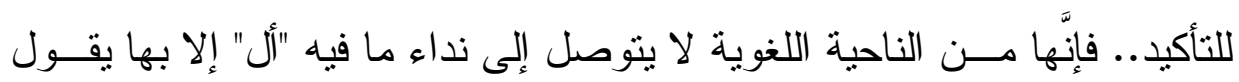

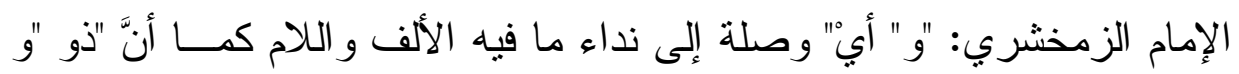
"الذي" وصلتان إلى الوصف بأسماء الأجناس ووصف المعارف بالجمل، وهـــ اسم مبهم مفتقر إلى ما يوضحه ويزيل إبهامه، فلا بُدَّ أن يردفه اسم جنس أو ما واله

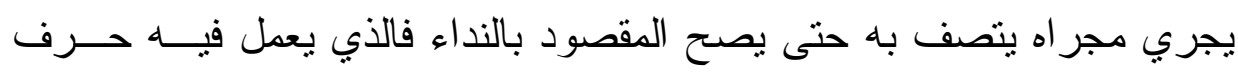

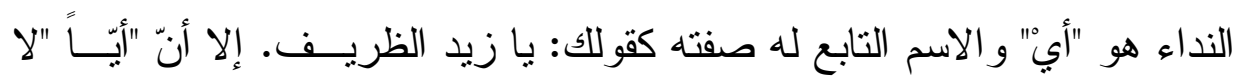
يستقل بنفسه استقلال زيد، فلم ينفك من الصفة "هـ (').

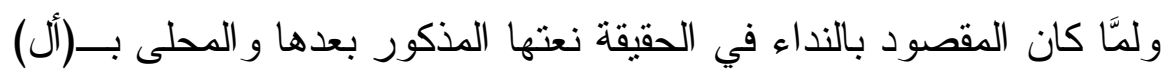

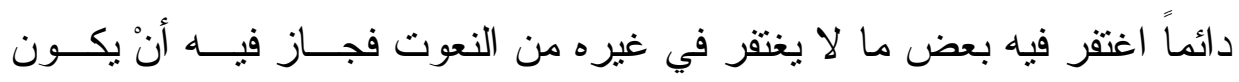

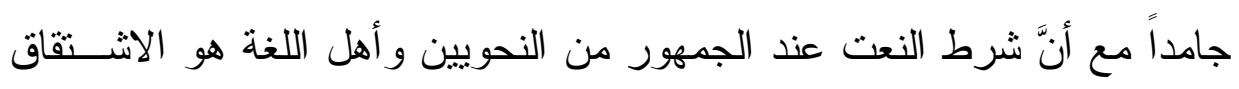

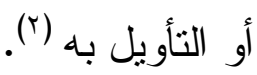

$$
\begin{aligned}
& \text { (1) الكثاف 1 1 19 (1). } \\
& \text { (Y) يقول ابن مالك في ألفيته: }
\end{aligned}
$$

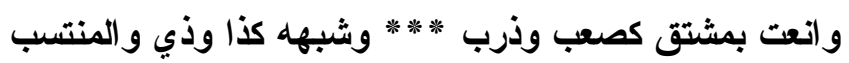

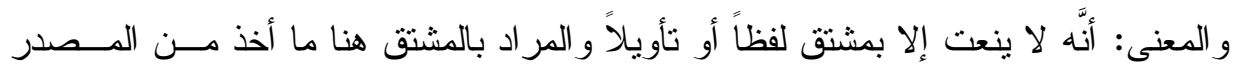

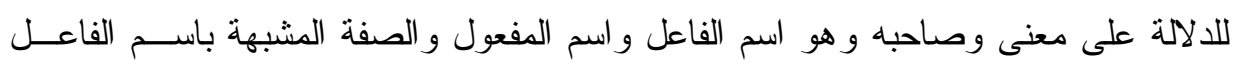

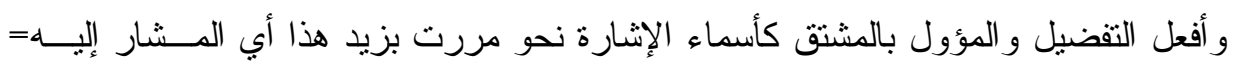


أوسّا عن تعليل مجيء "أي" مع "يا "للتوصل لنداء ما فيه "أل" فــ"لأنَّ" يا "تعد

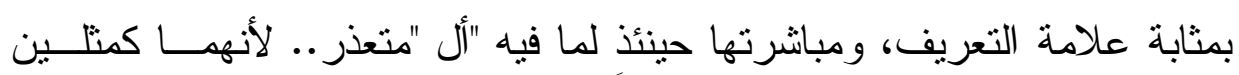

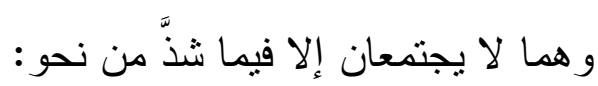

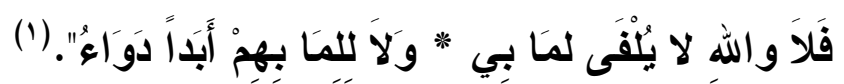

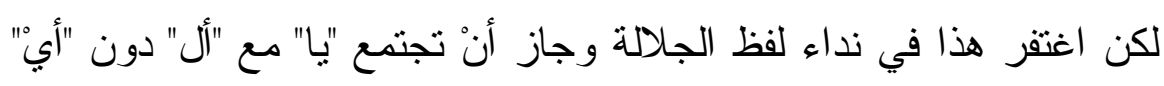
وتعلـــل ذلك:

أولاً: أنَّ "أل" في لفظ الجلالة صارت من بنية الكلمة.

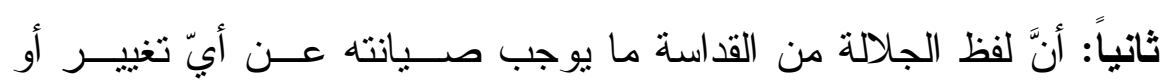
تحريف بنقص أو زيادة. ثالثاً: لم يحتج إلى "أي" في نداء لفظ الجلالة - طلباً لخفة هذا اللفظ علـى لهـ الألسنة، لكثرة ترديدها له لشدة الحاجة إلى ذكره في الدعاء و غيره.

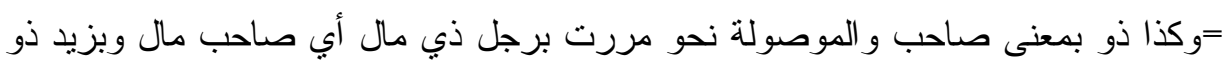

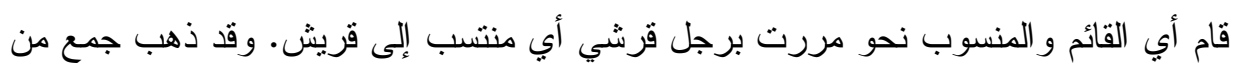

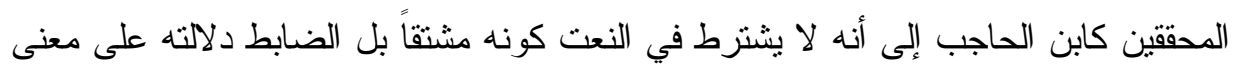
في منبو عة كالرجل الدال على الرجولية.

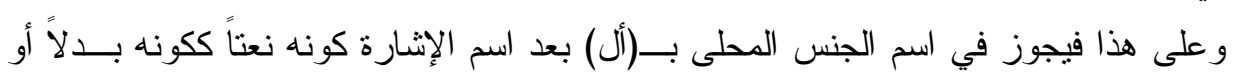

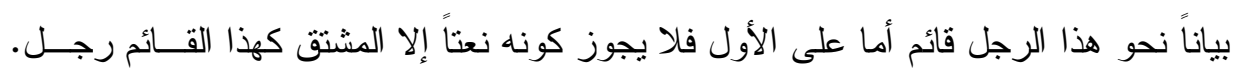
(حاثشية الخضري على ابن عقيل r - r r م).

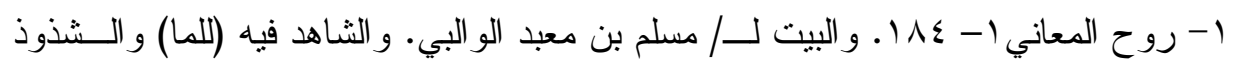

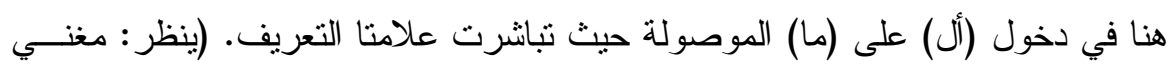

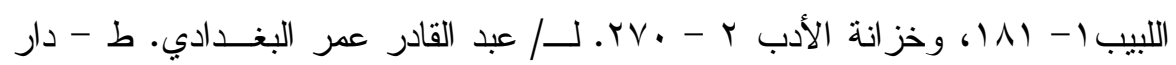

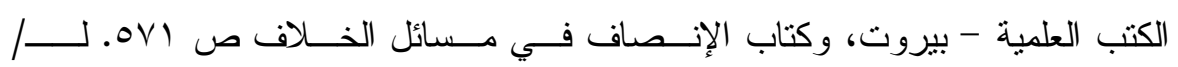

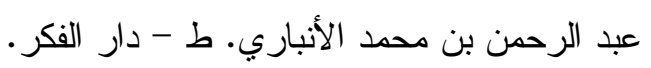


رابعاً: أنَّ "أيه" نكرة تحتاج بعدها اسم جنس، أو ما يجرى مجر اه يوضـــهـ ويزيل إبهامه، ولفظ الجلالة ليس من هذا القبيل، فلا يتتاســب معــه أن يـسبقه "أي".

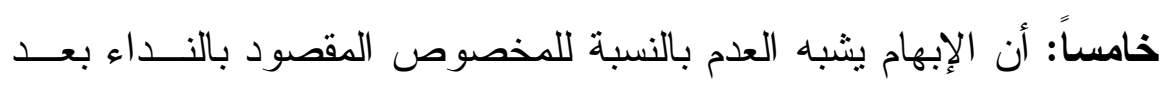

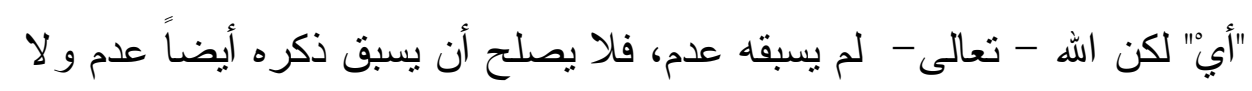
شبه عدم.

سادساً: أنَّ في رفع "أبي" من بين حرف النداء "يا "وبين لفـــ الجلالــــة أي "المنادَى" إثنارة إلى قرب الله ممن ناداه، و أنه ينبغي رفع كل الوسطاء بين العبد

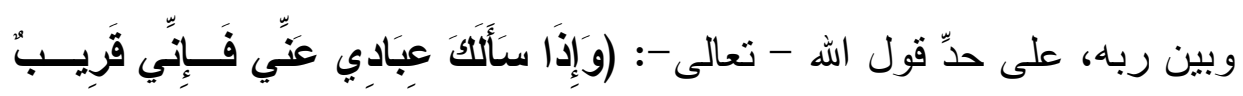

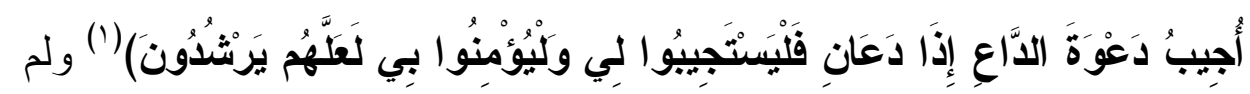
يقل: فقل: إني قريب(r). هذا عن "أي" فماذا عن "ها" التتبيه وحكمتها؟ قبل الإجابة على هذا أثنير في البداية أنه عندما نقول "ها "التتبيه فهذا أحــــ وجوه ثناثة ذكرت في استخدامها..

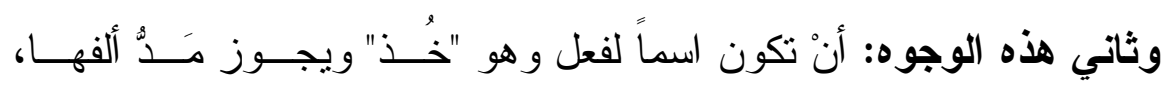
ويستعملان - أي: ها وهاء - بكاف الخطاب وبدونها، ويجوز في المــدودة أن يستغنى عن الكاف بتصريف همزتها تصـاريف الكاف؛ فيقـال "هَــاءَ" للمــذكر

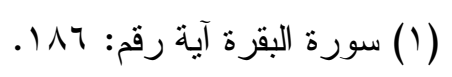

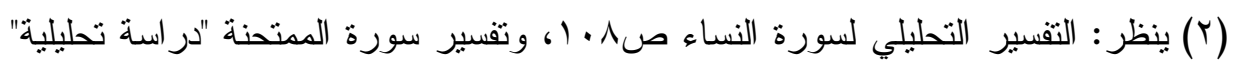

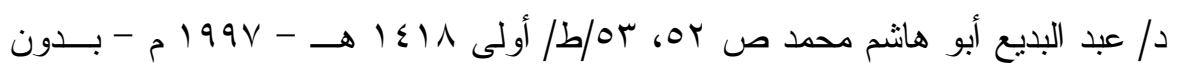
ذكر اسم المطبعة. 


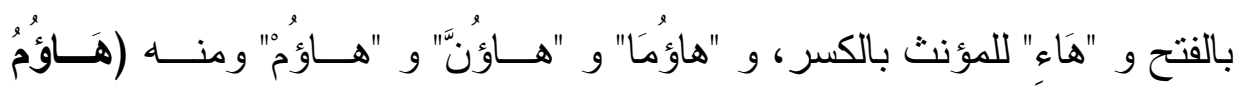

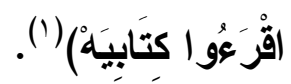

وثالث هذه الوجــوه: أن تكون ضمير اً للمؤنث، فتستعدل مجرورة الموضع

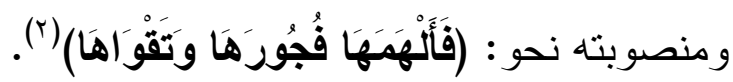

ونعود إلى استخدام "ها" للتتبيه لنقول: إنها تكون للتتبيه على أربعة أوجـــهـ

ذكر ها ابن هشام في المغني وهي:

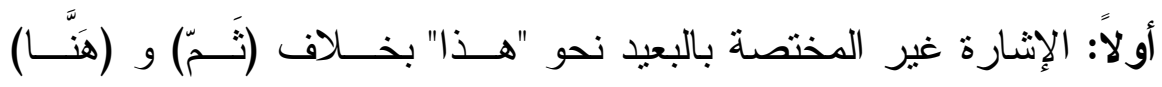

بالنتنديد و (هُناللك).

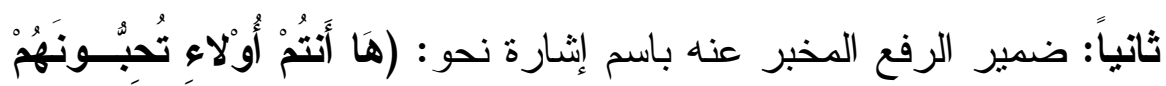

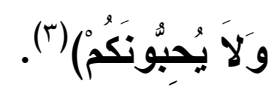

ثالثاً: اسم الله - تعالى - في القَسم عند حذف الحرف، يقال "هَا اللهِ" بقطــع الهززة ووصلها..

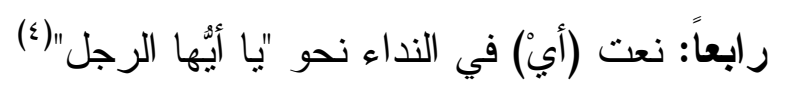

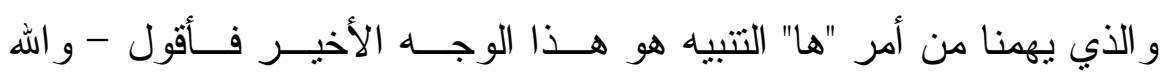

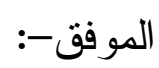

ذكر العلماء لـــ "ها" حينما تدخل على "أي" في النداء فائدتين:

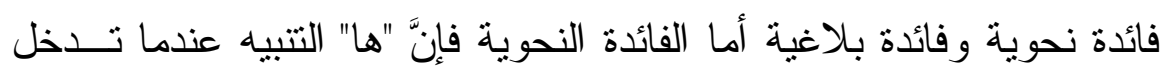
على "أي" تكون عوضاً مما يستحقه (أيْ) من الإضافة، وفي ذلك يقول الإمــام

$$
\begin{aligned}
& \text { (1) سورة الحاقة آية رقم: } 9 \text { 1. } \\
& \text { (Y) سورة الثمس آية رقم: } 1 .
\end{aligned}
$$

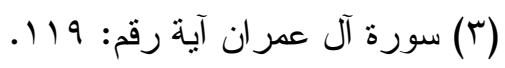

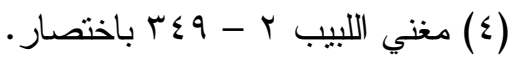


القرطبي: "وجاءوا بها عوضاً عن ياء أخرى، و إنِّما لم يأتو ا بياء لــئلا ينقطــع

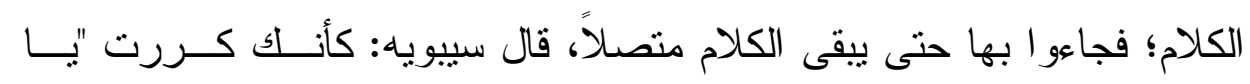
"مرتين وصار الاسم بينهما؛ كما قالو ا: ها هو ذا"هــ (')

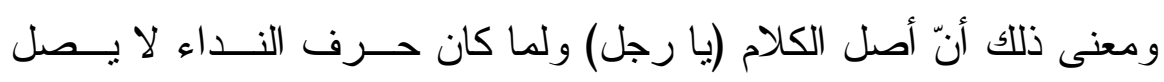

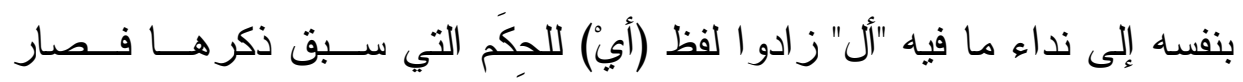
التركيب (يا أي الرجل) و هكذا وقع الفصلُ بين حرف النداء و المنادى مما أحوج إلى تكرار حرف النداء ملصقاً بالمنادى ليكون (يا أي يا الرجل) ولما في هــذا التزكيب من الإشكال الأول ذاته - أبي عدم مباشرة حرف النداء لمـــا فيـــه (أل)

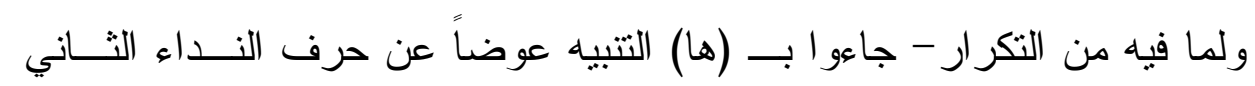
فصار التركيب - كما نزى - (يا أيها الرجل).

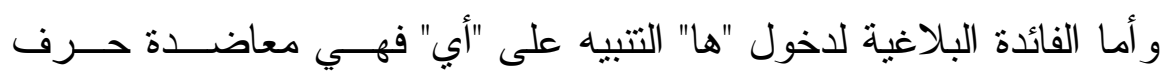
النداء ومكاتفته بتأكيد معناه.. ومن الممكن بيان حكمة هذا التتبيه في "ها" الدال على معاضـــدة ومكاتفـــة حرف النداء لتأكيد معناه فيما يلي: أولاً: الإرشاد إلى أهمية الأمر المنبّه إليه، ضرورة أنه لا يحسن التببيه من

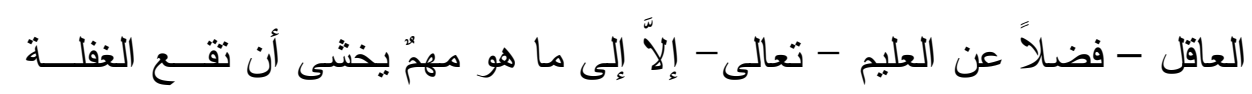
عن أهميته لو لا التتبيه إليه.

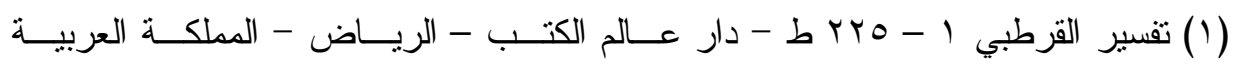

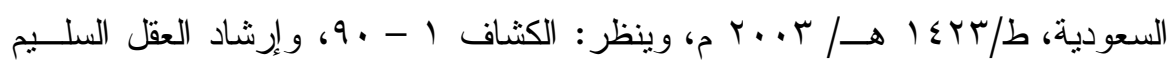

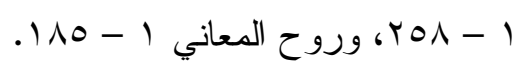


ثانياً: تجلية رحمة الهه الواسعة ونعمته السابغة على عباده بتتبيه8هم إلى مسـا

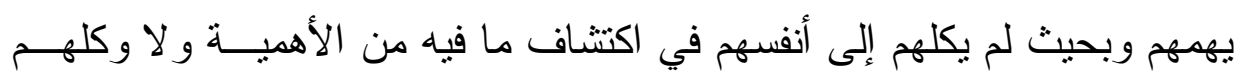
إلى الغفلة التي يمكن أن تعتريهم فتحول دون تتبههم إليه.

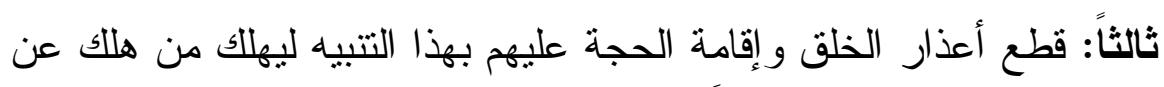

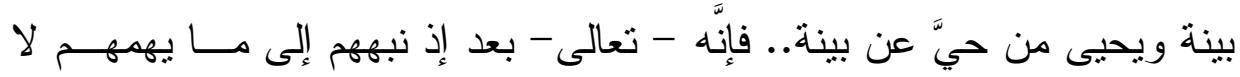

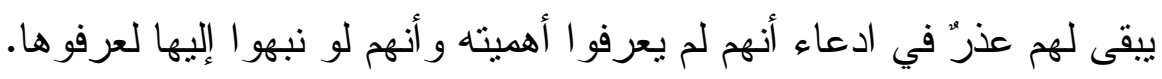

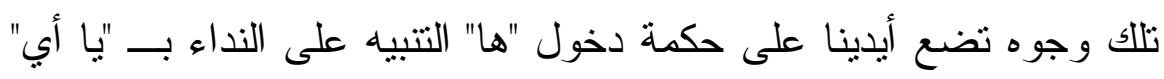

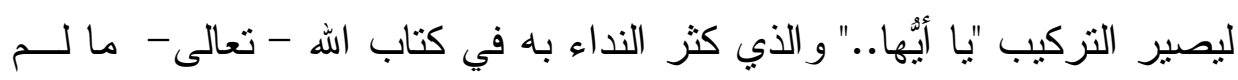

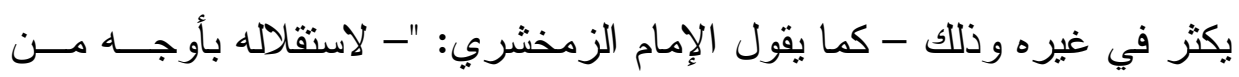

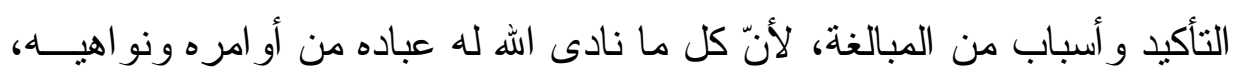
و عظاته وزو اجره وو عده وو عيده، و اقتصاص أخبار الأمم الدارجة عليهم. و غير ذلك مما أنطق به كتابه أمور عظام وخطوب جسام وفئه ومعان عليهم أن

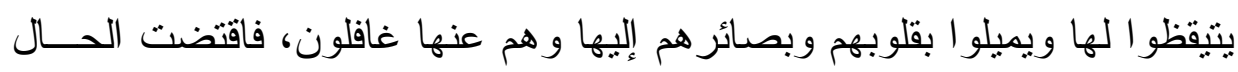

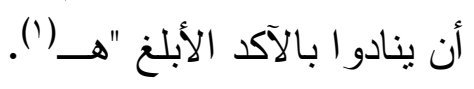
ويختصر الإمام الألوسي هذه المعاني الكامنة في النداء بــــا "يأيُها" فيقول: وكثر النداء في الكتاب المجيد على هذه الطريقة لما فيها من التأكيد الذي كثيـراً

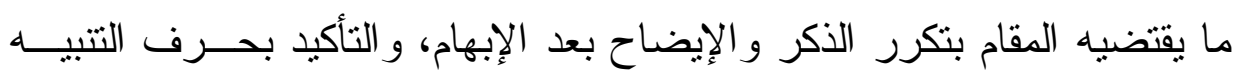

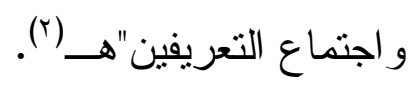
وبهذا يتت الكلام عن هذا التركيب الذي كثر النداء به في كتاب الله -تعالى -

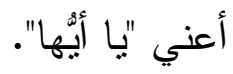
وفيما يلي استعر اض أنواع النداءات الإلهية في القرآن الكريم.

$$
\begin{aligned}
& \text { (1) الكثاف 1 - .9. }
\end{aligned}
$$

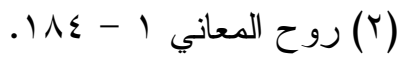




\section{الفصل الثاني}

\section{أنواع النداءات الإلهية في القرآن الكريم ومغرزاه}

مما لا شك أنَّ النّداء - وكما سبق ذكره - يعدُّ في كتاب اله - تعالى - أحد

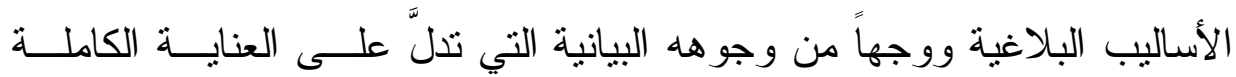

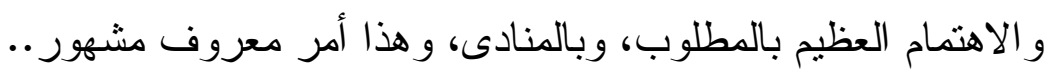

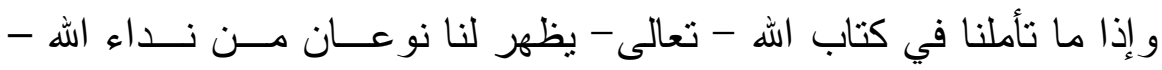

تعالى - الموجه إلى خلقه وهذان النوعان هما: نداء تكويني، ونـــــاء تكليفــي. وفيما يلي تفصيل ذلك.. 
الدكتور / خالد سعيد أحمد البسيوني

- rᄉ - 
المبحث الأول

\section{النداء التكميني}

ومعناه: نداء الله - تعالى - لغير العقلاء مما خلق، ومثاله: قوله - تعالى -

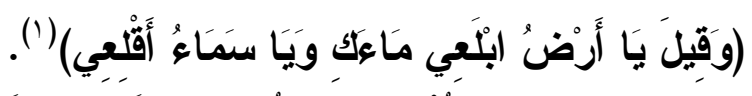

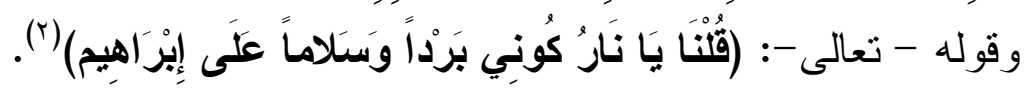

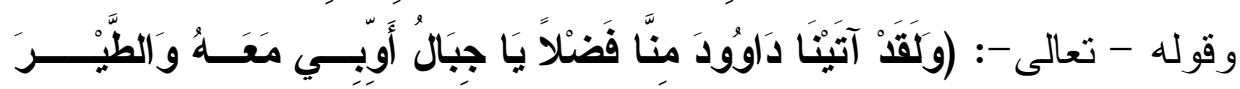

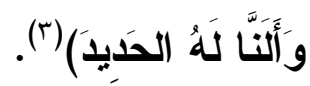
و هذه النداءات في القر آن الكــــيم تظهــر مطاو عـــة الكائنــات لخالقهــا،

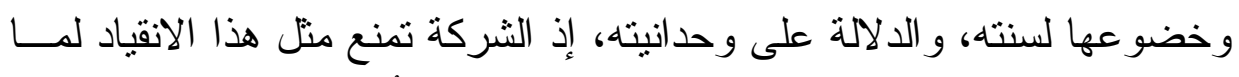

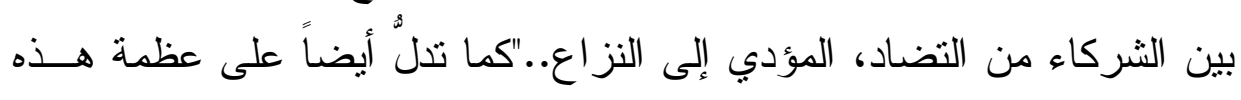

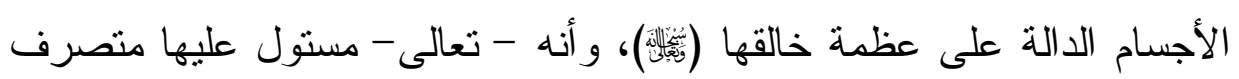

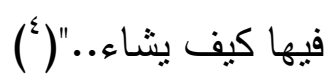
وقد اختلف العلماء في أمثال هذه النداءات وهل هي على الحقيقة بمعنى أن

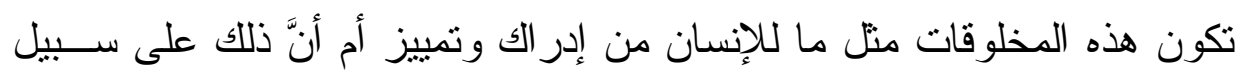

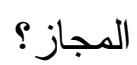
يذهب جمهور العلماء إلى أنَّ هـــه النـــاءات مــن رب العـالمين لهـــه المخلوقات من الأرض و السماء والجبال.. إلى غير ذلك إنما هو لهو على الاستعارة

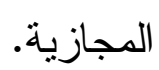

$$
\begin{aligned}
& \text { (1) سورة هود من الآية رقم: ؟ ؟. } \\
& \text { (r) (r) سورة الأنبياء آية رقم: } 19 .
\end{aligned}
$$

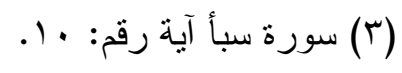

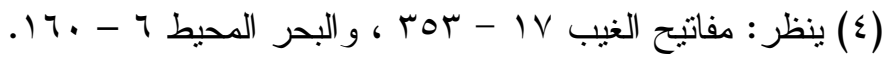


يقول الإمـام الزمخثري: "نَادَى الأرضَ و السماءَ بما يُنــادَى بـــه الإنــسـان المميز على لفظ التخصيص، و الإقبــال عليهمـــا بالخطــاب مــن بــين ســائر المخلوقات..، كأنها عقلاء مميزون قد عرفو ا عظمته وجلالته وثو ابــهـه وعقابــهـ

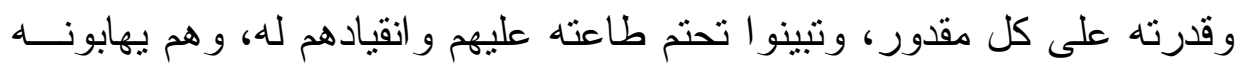
ويفزعون من التوقف دون الامتثال له و النزول على مشيئته"هـ ('). ويؤكد الإمام الرازي على ذلك بقوله: "ليس المر اد أنه - تعــالى - يــأمر

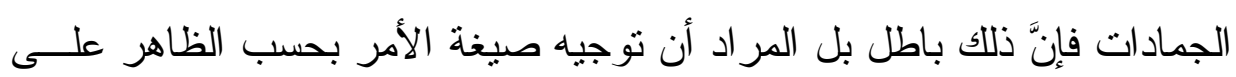

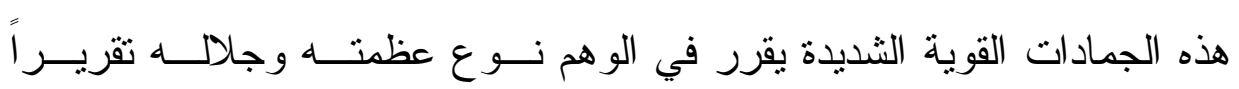

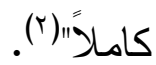

ويقابل هذا القول أن نداء هذه الأشياء السابق ذكرها لا مانع مــن إجر ائــــ

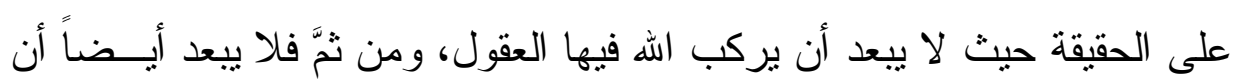
تتادى كما ينادى العقلاء من الملائكة و الإنس و الجن (r).

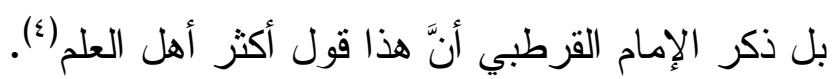

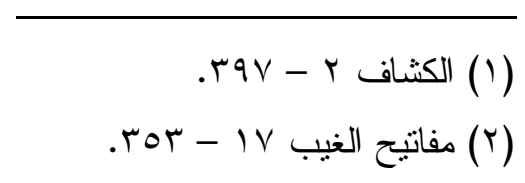

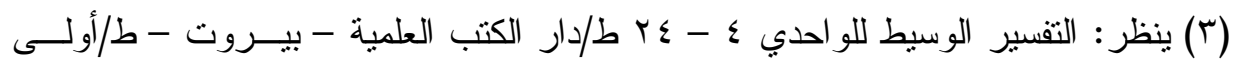

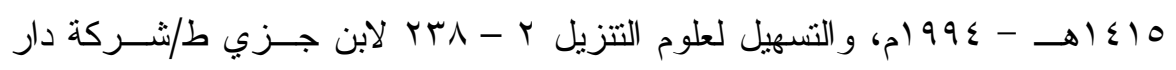

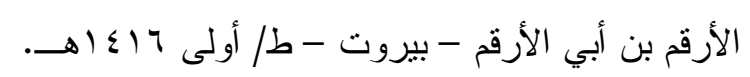

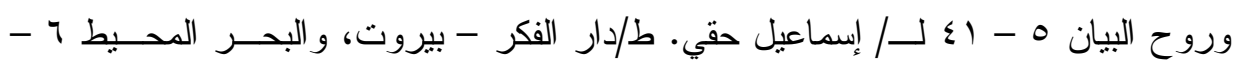

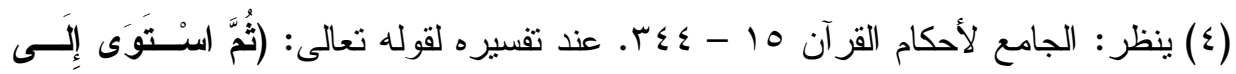

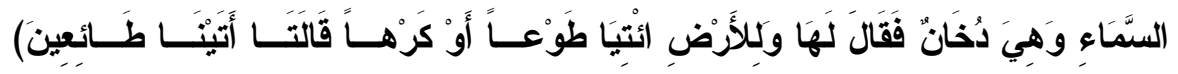

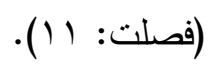


كما أننا نجد في القرآن الكريم بعض هذه النداءات وهي تدور بــين تلـــك

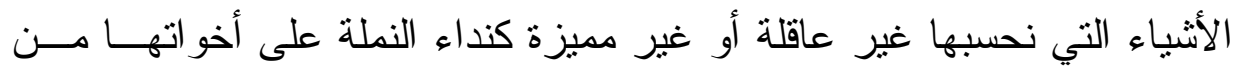

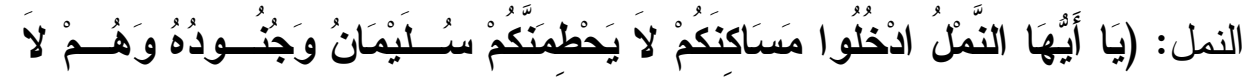

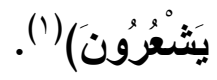

مما يؤكد على أن لها إدر اكاً خاصاً يصلح معه نداؤها..

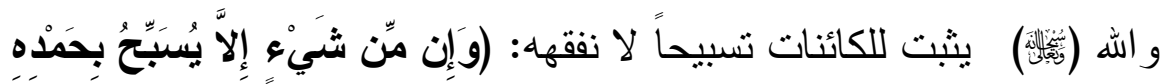

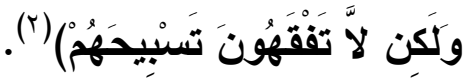

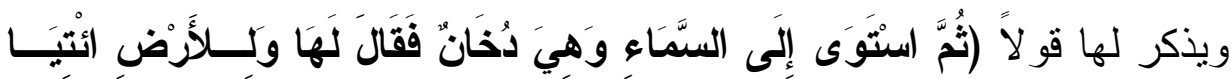

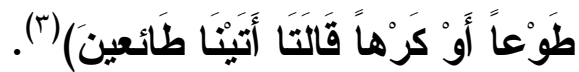

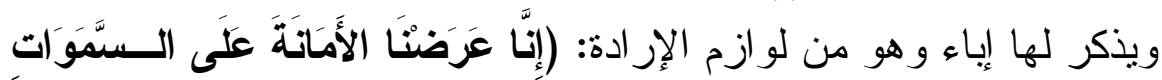

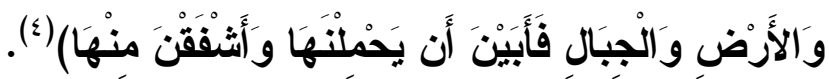

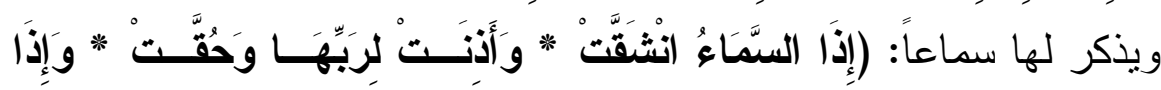

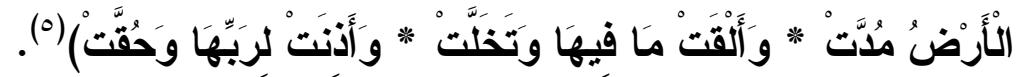

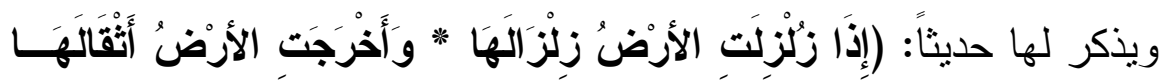

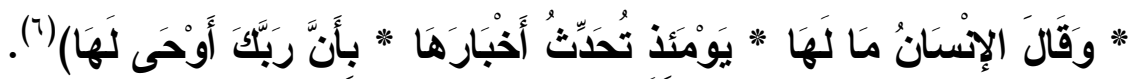

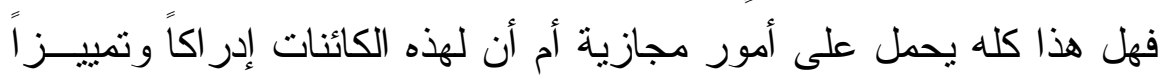

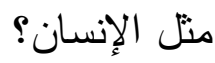

$$
\begin{aligned}
& \text { (1) سورة النمل آية رقم: 11. }
\end{aligned}
$$

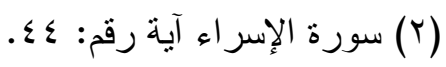

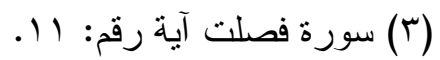

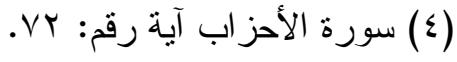

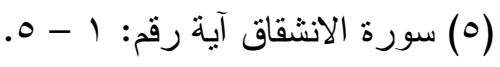

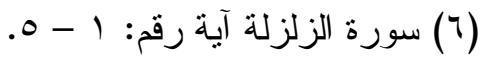


الحاكم في ذلك كله هو أوضاع اللغة وضو ابطها، و إن كان العقل لا يمنـع في جميع الأحو ال ما تمنعه أوضاع اللغة.

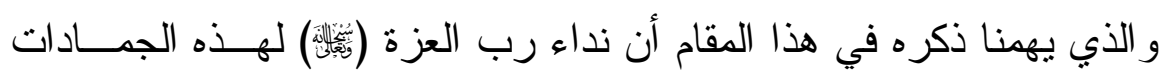

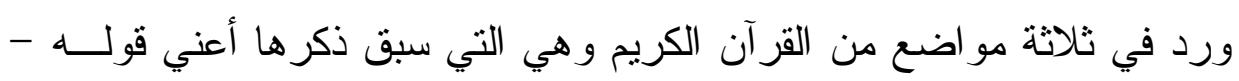

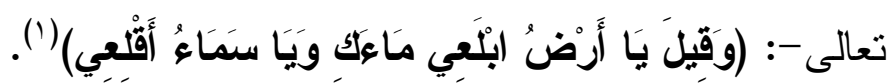

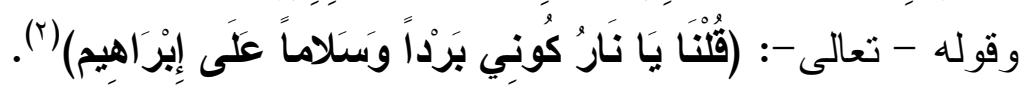

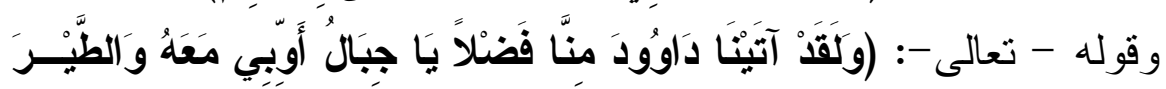

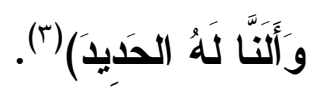
أما الموضع الأول فقد جاء في سياق الحديث عن قوم نوح وما جرى لهـــ

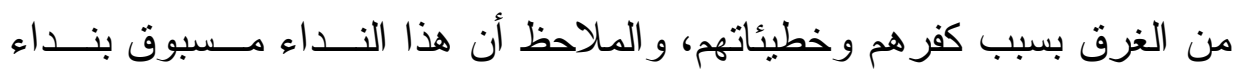

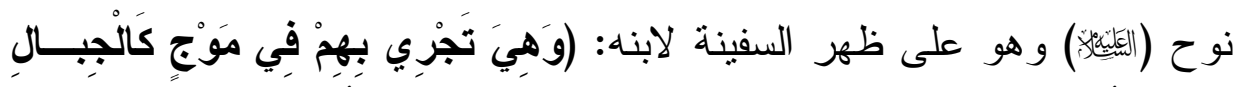

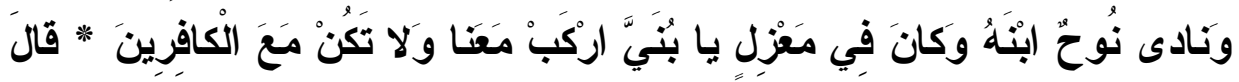

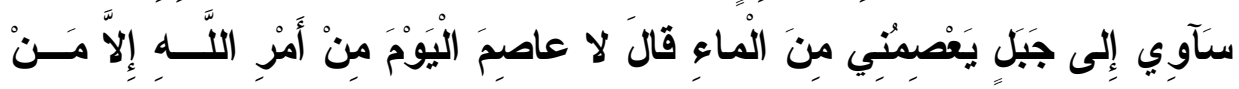

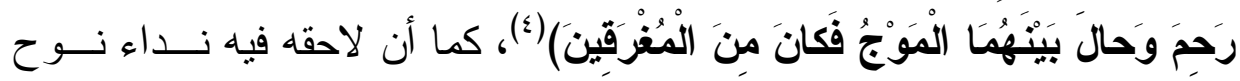

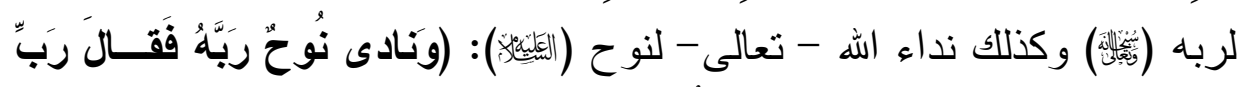

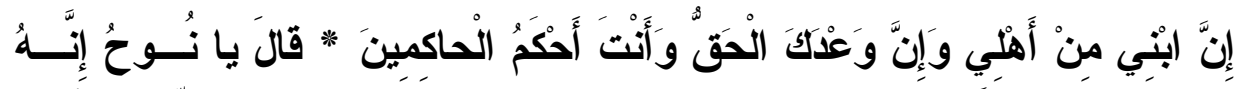

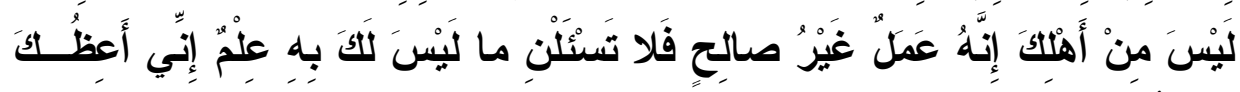

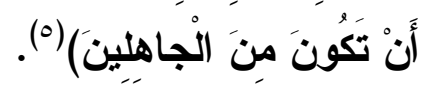

$$
\begin{aligned}
& \text { (1) سورة هود من الآية رقم: ؟ع. } \\
& \text { (Y) سورة الأنبياء آية رقم: } 79 \text { (Y) الاية رقد }
\end{aligned}
$$

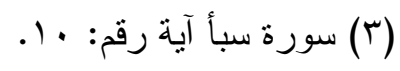

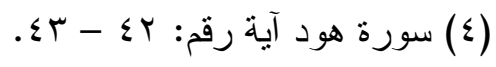

$$
\begin{aligned}
& \text {. }\{7-\leqslant 0:
\end{aligned}
$$


السياق أكثره نداء يناسب الموقف الذي جرت فيه القـــة مــن الإهــلاكك و الدمار و الاضطر اب...

يقول صاحب الظلال: "و إننا بعد آلاف السنين، لنمسك أنفاسنا- ونحن نتــابع السياق - و الهول يأخذنا كأننا نشهد المشهد. و هي تجري بهم في موج كالجبــال، ونوح الو الد الملهوف يبعث بالنداء تلو النداء. و ابنه الفتى المغرور يأبى إجابـــة

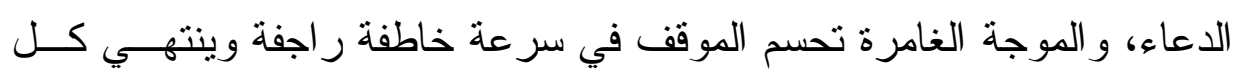
شيء، وكأن لم يكن دعاء و لا جو اب!.."هــ"(').

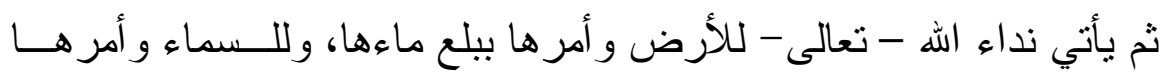

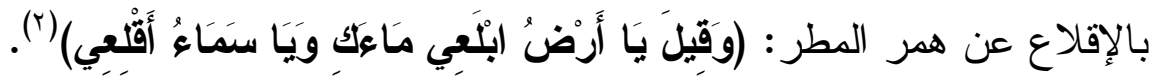
وقد تكلم العلماء عن بلاغة هذه الآية الكريمة بكلام كثير، لا بتسع المقــام

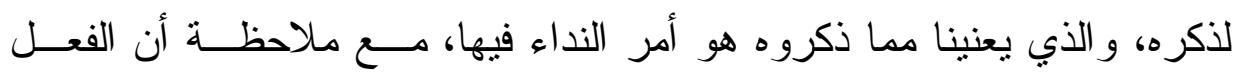
السابق لحرف النداء في هذه الآية قد بني للمجهول (وقيل).

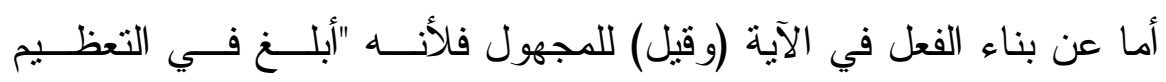

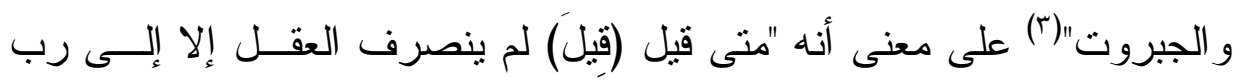

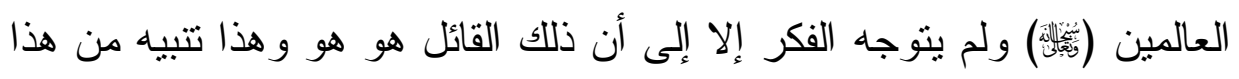

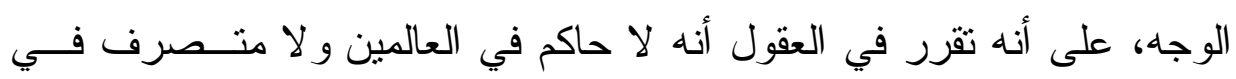
العالم العلوي و العالم السفلي إلاَّ هو "(؛).

(1) في ظلال القر آن ع - ا ـ للأستاذ/سيد قطب. ط/دار الثروق - بيروت - القاهرة، ط:

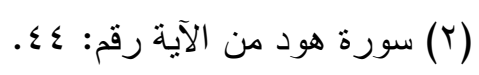

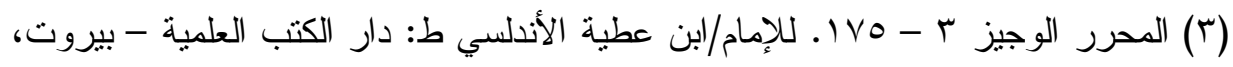

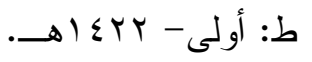

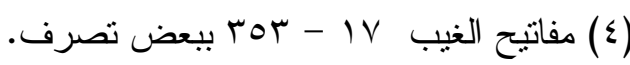


ثم يلي هذا الفعل نداء الأرض و السماء|(') "وقام نداء الأرض على السماء

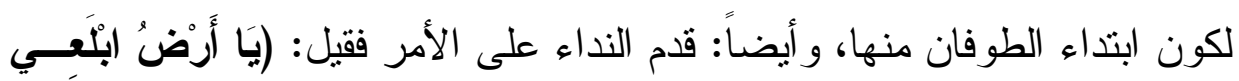

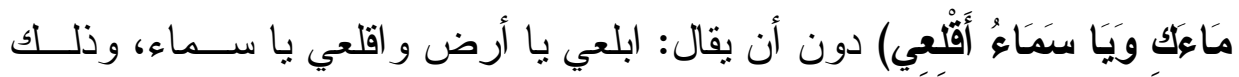

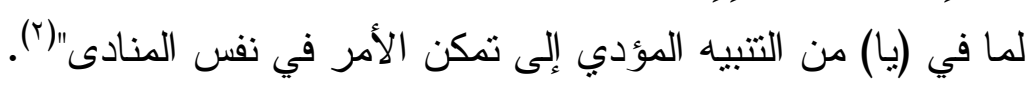
و العجيب أن سياق النداءات الواردة في هذا الموضع وفي سابقه و لاحقه لم

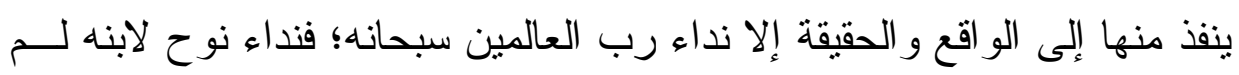

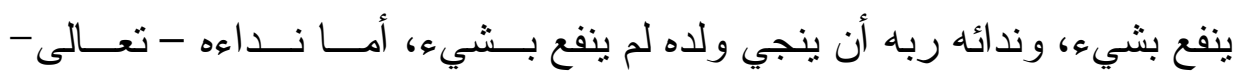

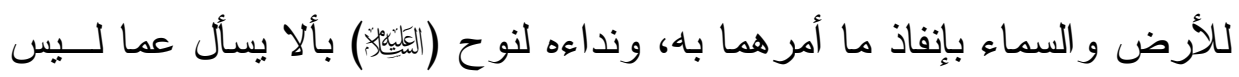

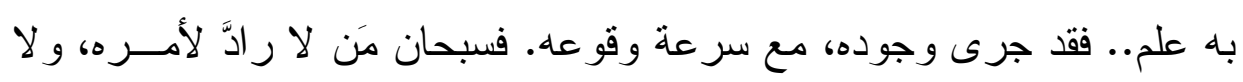
معقب لحكمه.

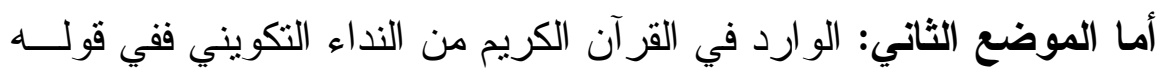

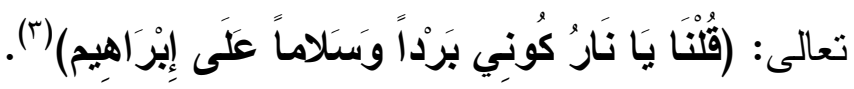

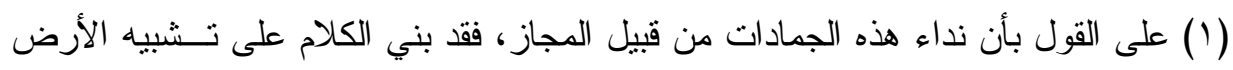

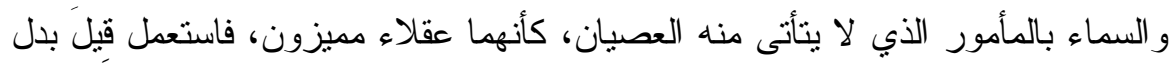

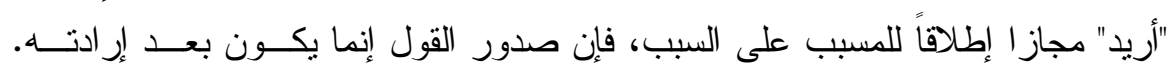

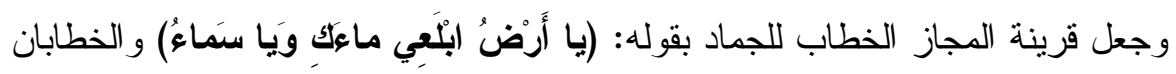

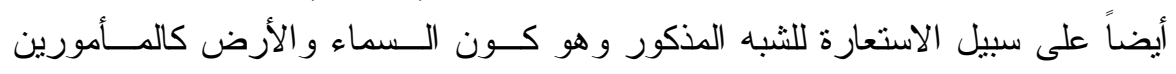

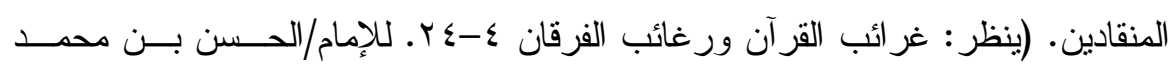

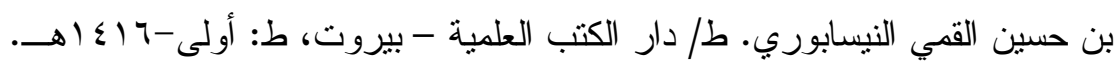

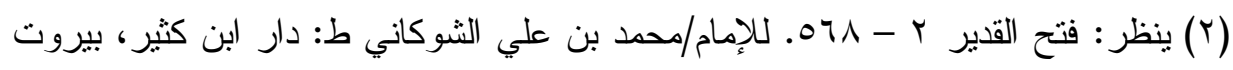

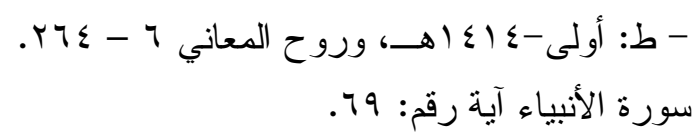




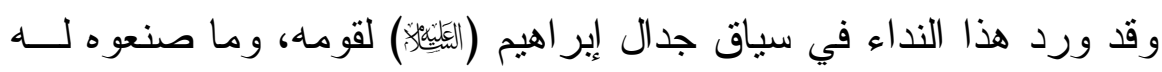
من نار عظيمة عبر عنها القرآن الكريم على لسانهم بأنها الجحيم (') ثخ إلقـائهم إبر اهيم (اليَلِنهِ) فيها.

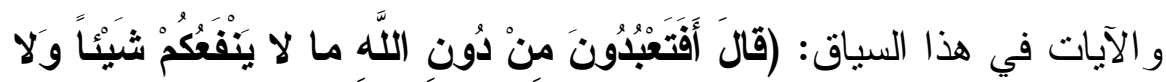

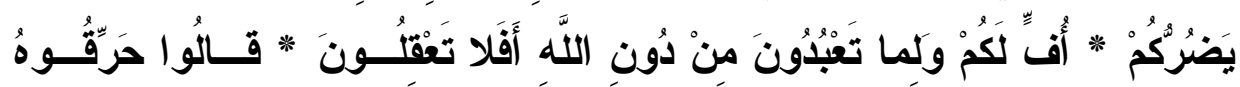

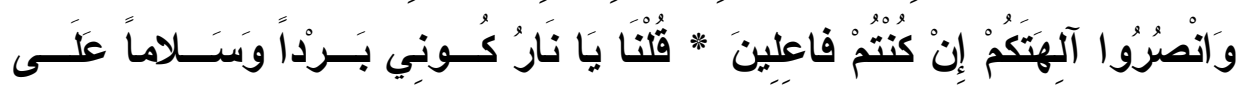

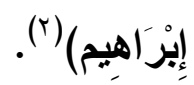
وقد جاء هذا النداء، من رب العالمين (لَّبلة) لهذه النار ليس فقط لأن تخرج

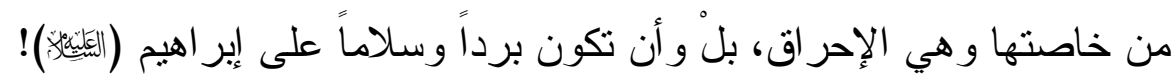

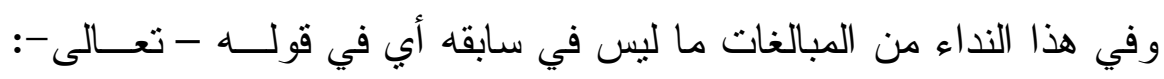

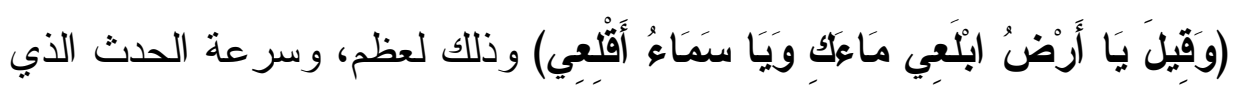
جرى فيه هذا النداء؛ ودل "على ذلكّ:

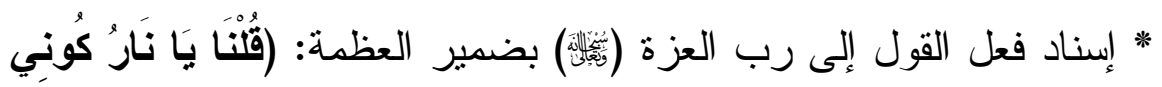

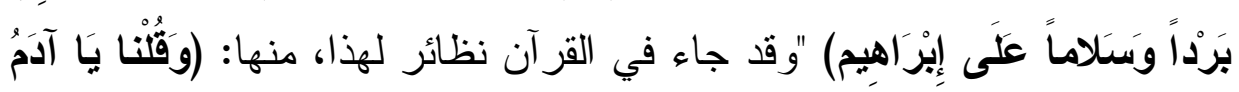

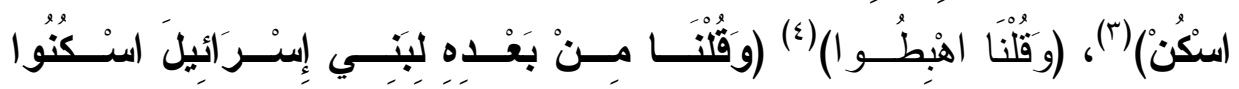

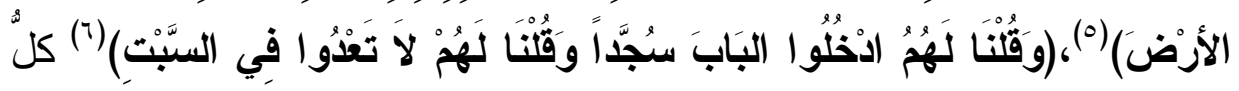

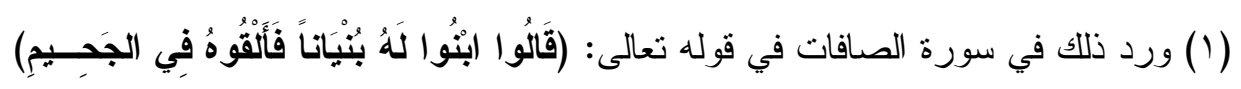

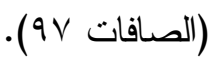

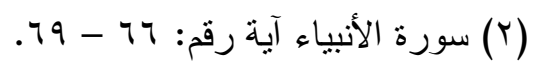

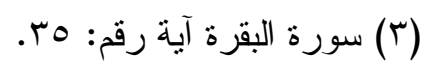

$$
\begin{aligned}
& \text { : }
\end{aligned}
$$

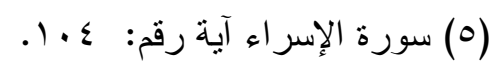

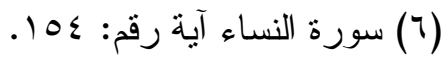


ذلك ورد فيه الفعل مسند إلى المتكلم المعظم نفسهُ، لأن الآمرَ اقتضى الاستعلاء على المأمور، فظهر للمأمور بصفة العظمة، و لا أعظم من اله - تعالى - "(')

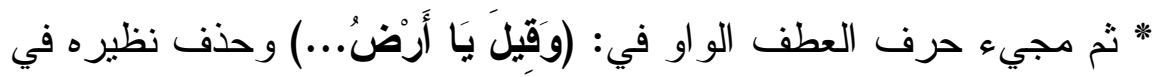

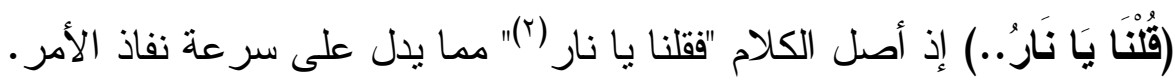

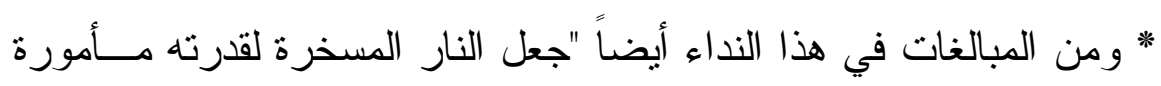

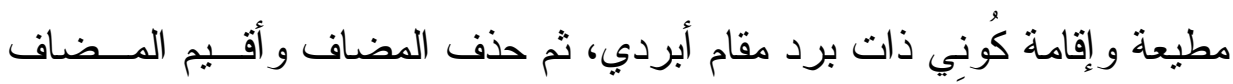
إلبيه مقامه" (")

و على القول بأن نداء هذه الجمادات مجاز عن التسخير، كما فــي قولــهـ:

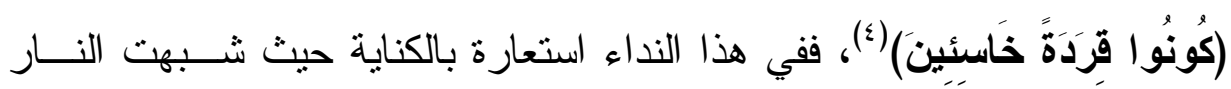
بمأمور مطيع، وتخييلها الأمرُ و النداء (०).

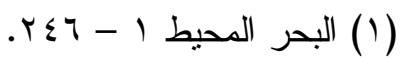

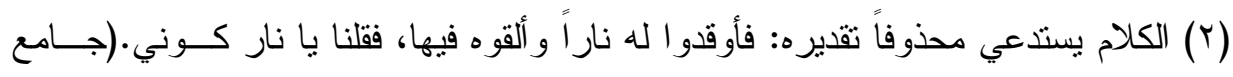

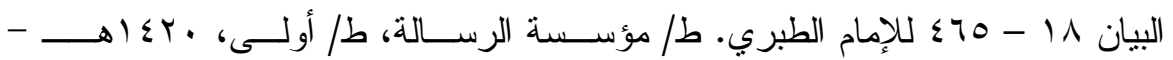

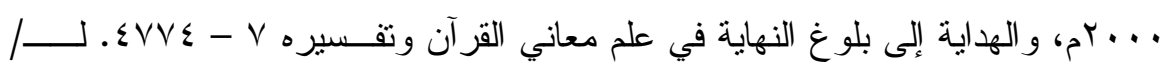

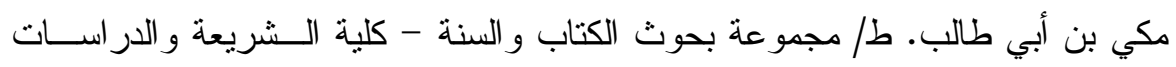

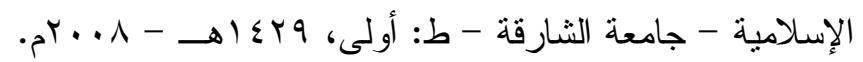

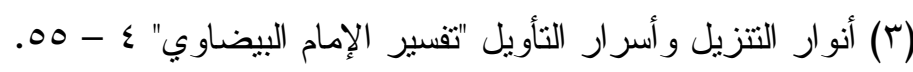

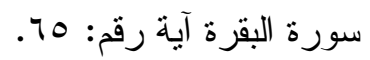

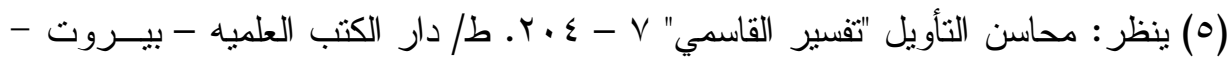

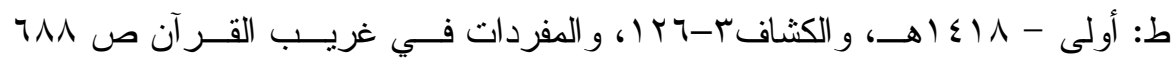

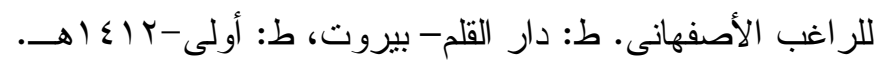


و الأكثرون على أنَّ هذا النداء والأمر في الآية على الحقيقة على معنى أن

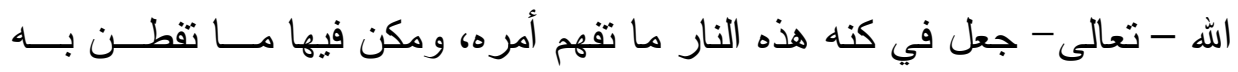
لذلك (')

و على العلات فخطاب التَّحويل و التَّكوين، لا يختصنُ بمن يعقل (؟).

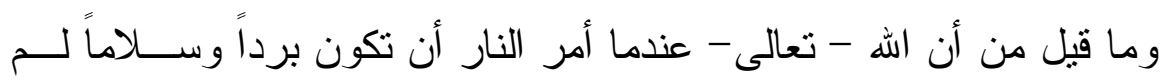

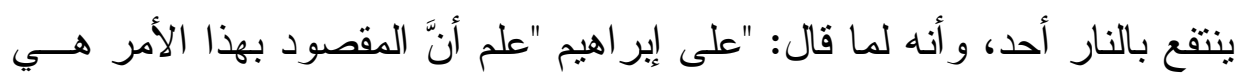

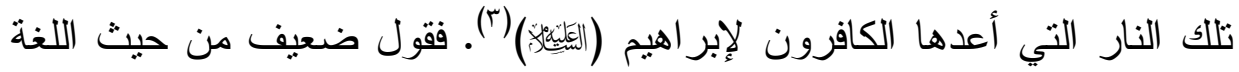
حيث "جاءت كلمة (نار) مرفوعة ونكرة مقصودة وكل اسم في النـــداء مرفــوع معرفة.

ومعنى كون المنادى معرفة أن يكون مر اداً به معين، سو اء كان معرفة قبل

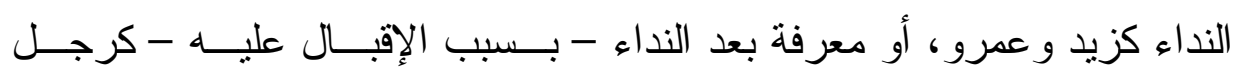

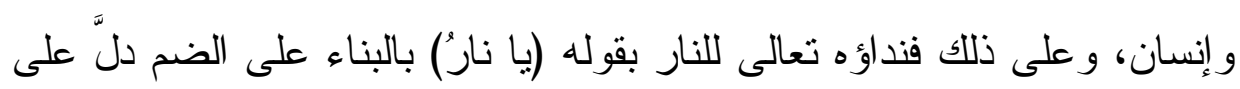

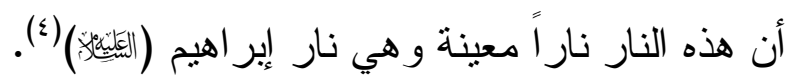

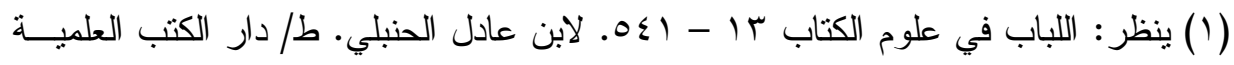

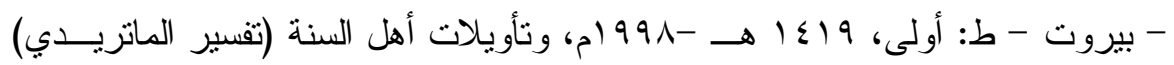

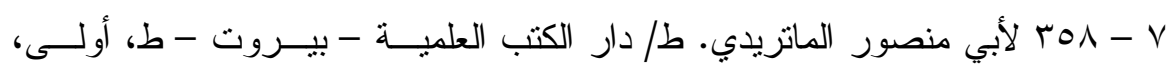

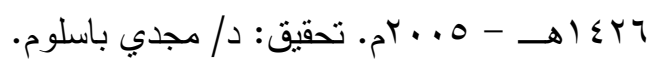

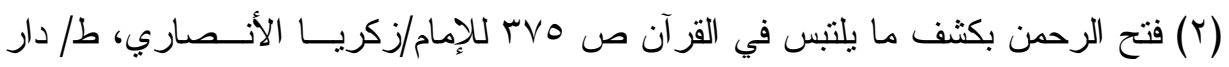
القر آن الكريم، بيروت - لبنان.

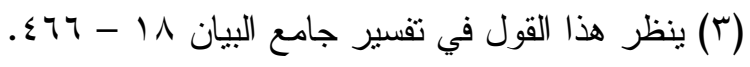

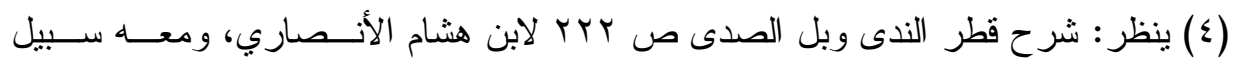

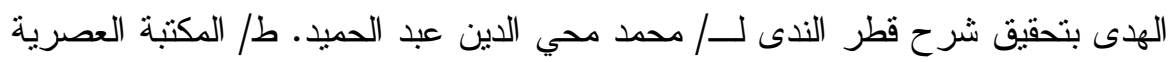

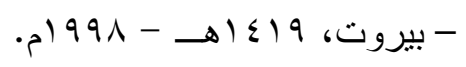




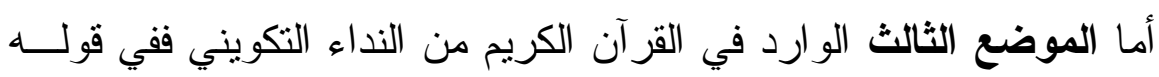

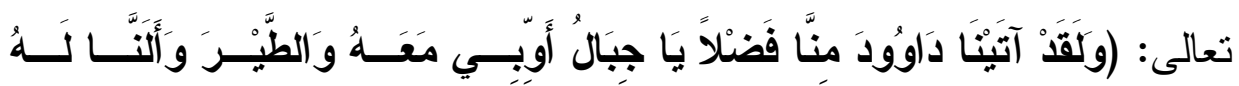

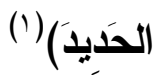
و النداء هنا للجبال و الطير معاً بأن ينتظما فـي ســـلك التـسبيح مــع داود

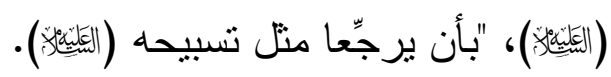

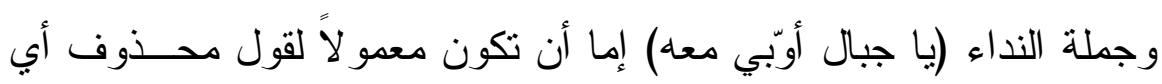

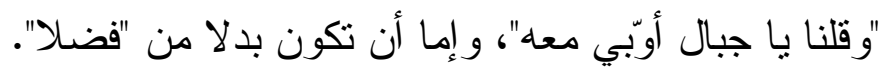

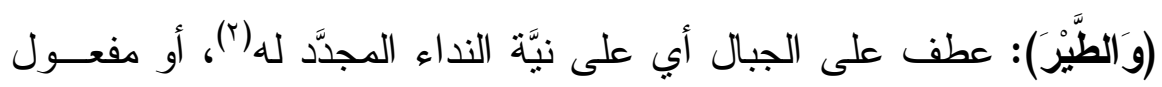
معه. أو مفعول به لفعل محذوف تقديره: وسخرنا لله الطير.

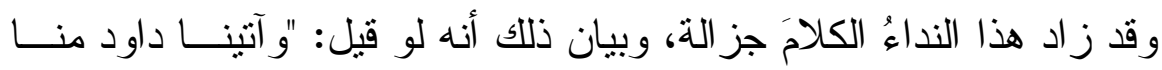

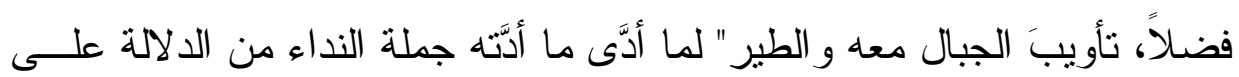

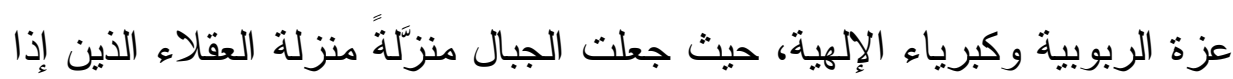

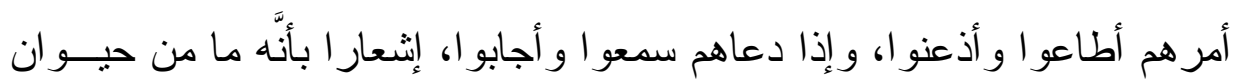
وجماد وناطق وصامت، إلا و هو منقاد لمشيئته غير مدتتع على إر ادته"(").

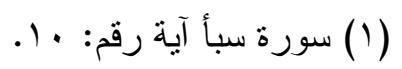

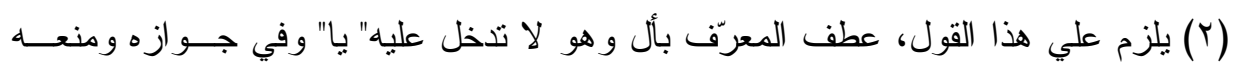

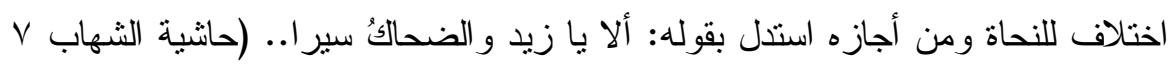

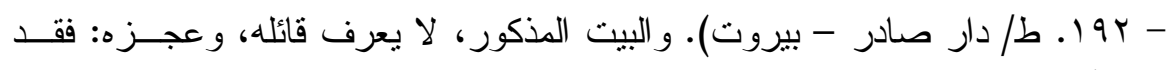

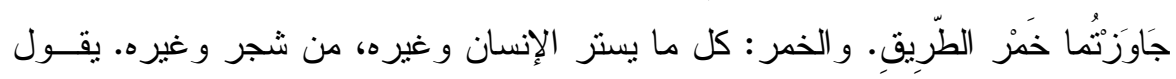

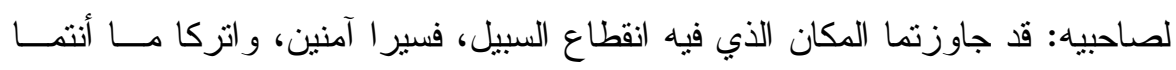

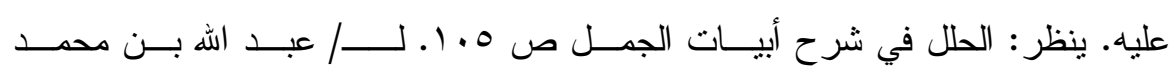

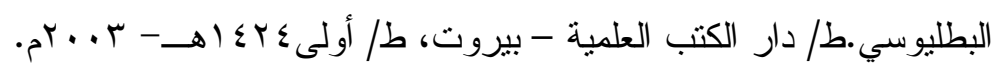

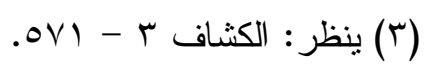




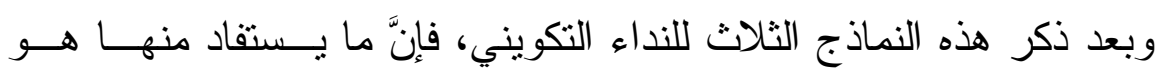

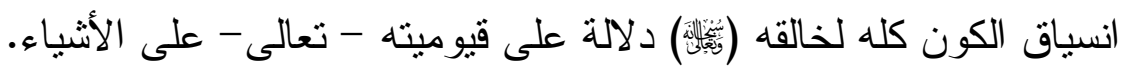
و على المشهور بأن "يا" لنداء البعيد فإنَّ مجئُها في هذه النداءات يفيد تعاظم

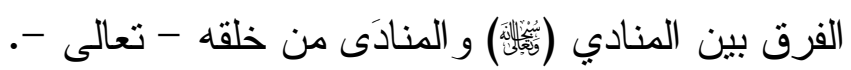

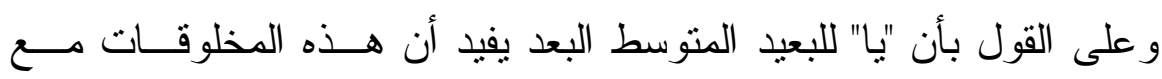
عظمها إنما هي في محكم تصرفه إيجاداً و إعداماً وتغييراً وتــصريفاً، وكمــال

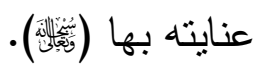
وفيما يلي ذكر النداء التكليفي و أنو اعه. 


\section{المبحث|اثاني}

\section{النـــاء التكليفي}

ومعناه نداء اله - تعالى - الموجه إلى العقلاء، وهو إمَّا أنْ يتضمن أمسـراً

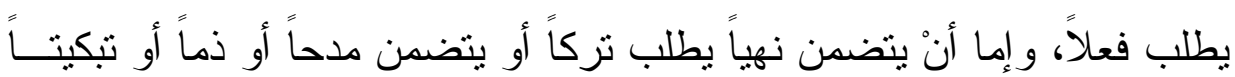

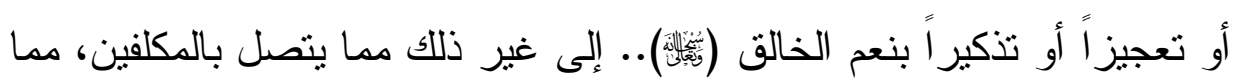
سيلي ذكره من خلال المطالب التالية.

\section{المطبب الأول \\ هن أنواع النداء التكايفي}

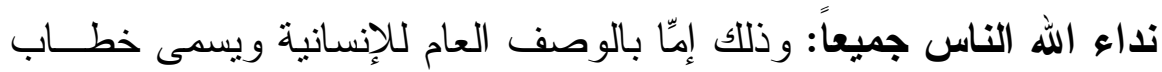

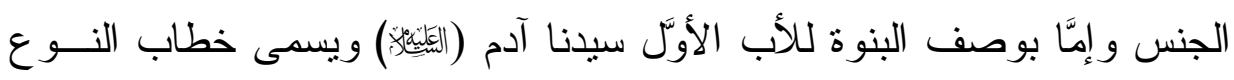

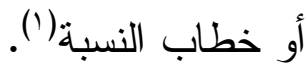

أما الأوَّل: فيكثر عندما يتعلق النداء بالأصول العامة للاين، مــن الإيمـان

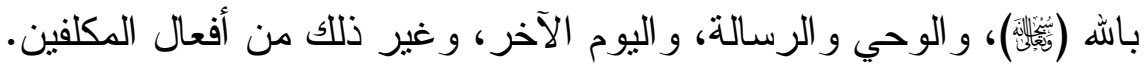

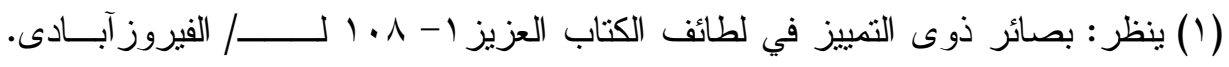

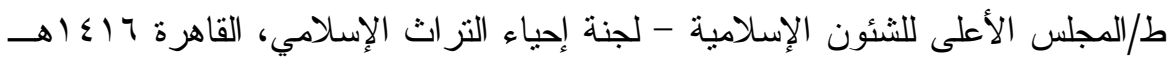

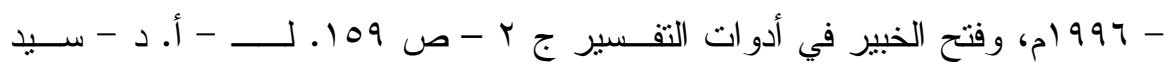

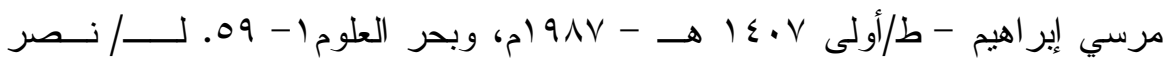
بن محمد السرقندي. ط/دار الفكر - بيروت. الهي 
وقد ورد نداء الله الناس في القرآن الكريم عشرين مرة(')، أكثرها فــي الـسور

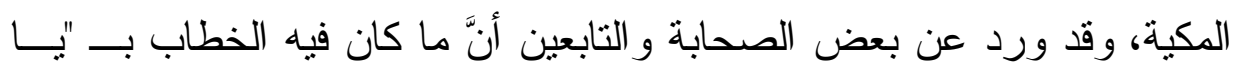

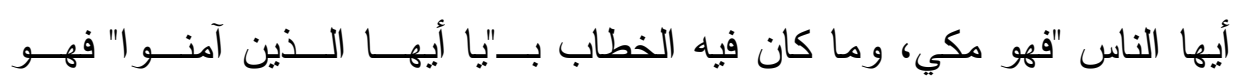

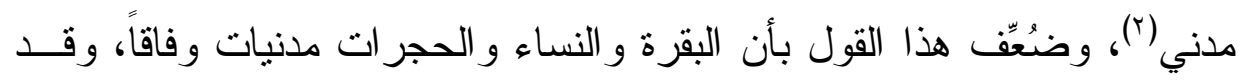
ورد في كل منها "يا أيها الناس"، و عليه فهذا القول أكثري لا كُّي (َّ). ومن ورود عموم النداء في القرآن بوصف الإنسانية: قوله تعالى مثنلاً: (يَا

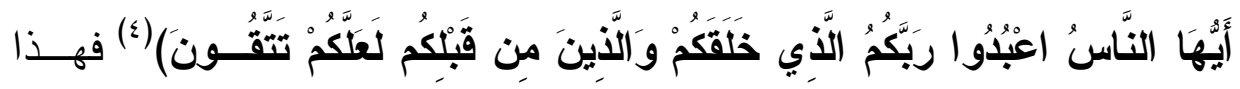

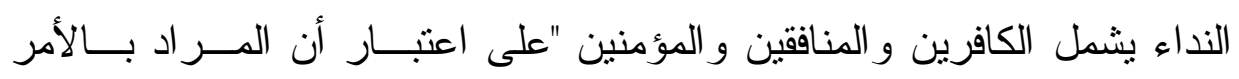

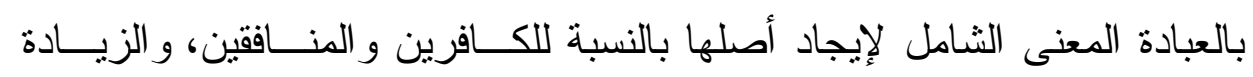

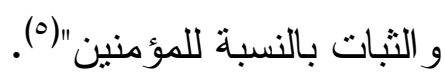

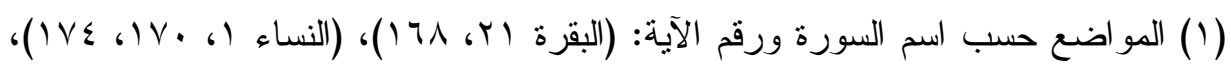

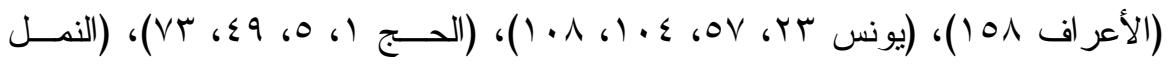

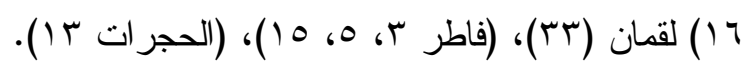

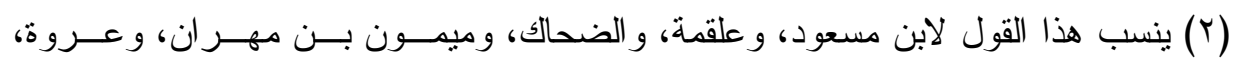

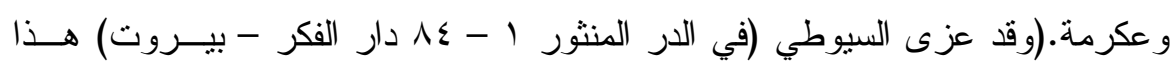

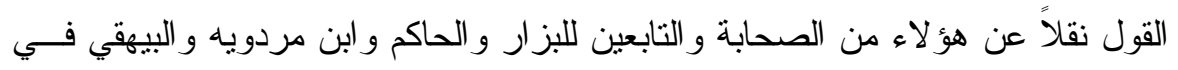

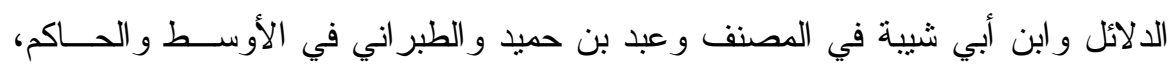

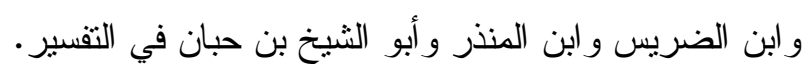

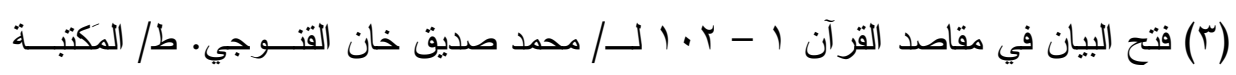

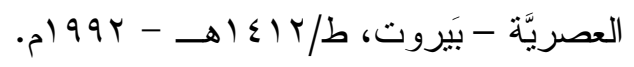

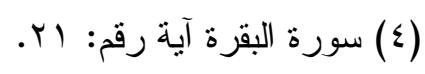

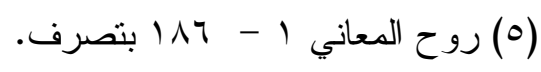




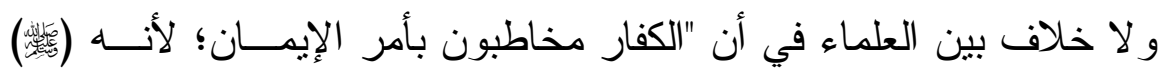

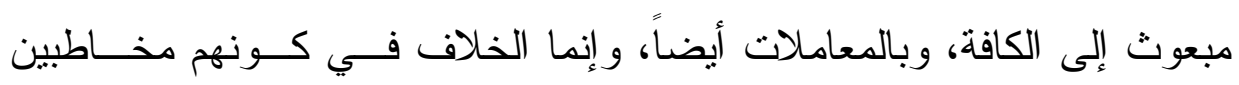

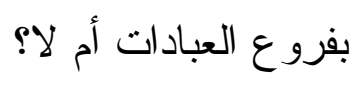

و المر اد بكونهم مخاطبين بفروع العبادات لدى من قال بذلك أنهم مؤ اخذون

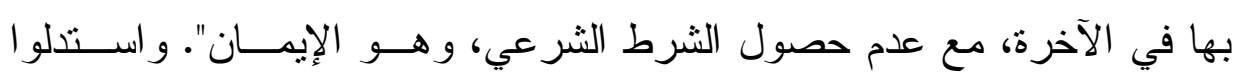

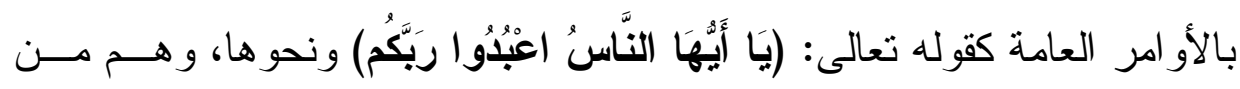
جملة الناس. و استدلو ا أيضًا بما ورد من الوعيد للكفار على الترك كقوله تعالى:

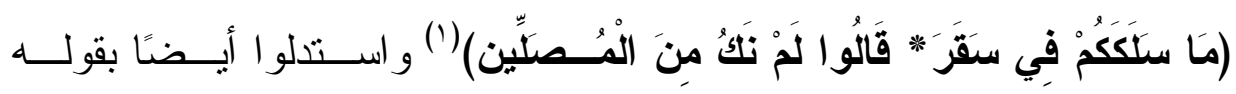

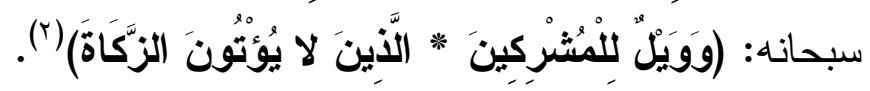

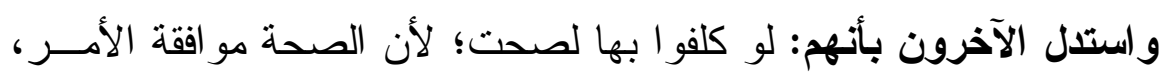

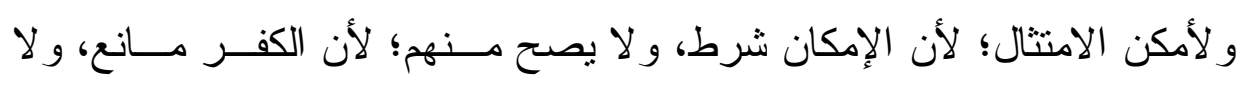

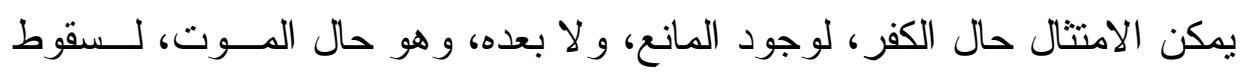

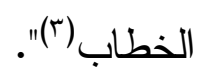
إلى غير ذلك من أدلة تتظر في كتب الأصول. وكما اختلف في كون الكفار مخاطبين بفروع العبادات، اختلف أيضا فـي في في

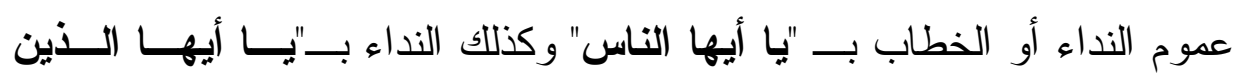
آمنوا" لمن بعد الحاضرين مهابط الوحي، فعند الجمهور لا بشملهم و إنما يثبــت حكمه لهم بدليل آخر من نص أو قياس أو إجماع وأما بمجــرد الـــيغة فـــــلا.

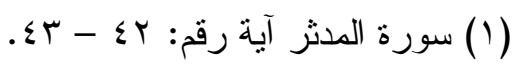

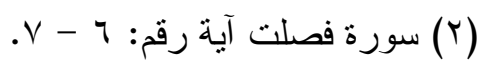

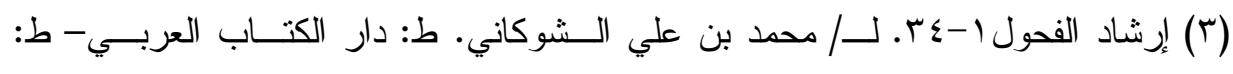

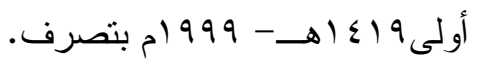


وقالت الحنابلة: بل هو عام لمن بعدهم إلى يوم القيامة و استدل الأولون بأنـــهـ لا

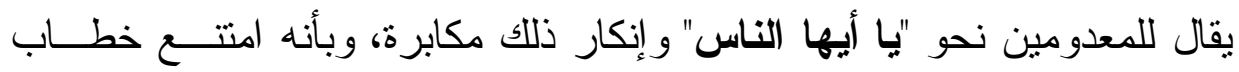
الصبي و المجنون فالمعدوم أجدر أن يمنع لأن تتاوله أبعد، واســندل الآخــرون ولهن

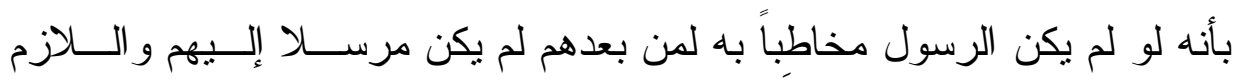
منتف ('). إلى غير ذلك مما يطول الكلام فيه.

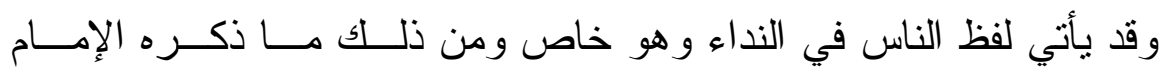
الثافعي في كتابه المسمى بـ (الرسالة) تحت عنوان "باب بيان ما نـزل مـــن الكتاب عام الظاهر ير اد به كله الخاص".

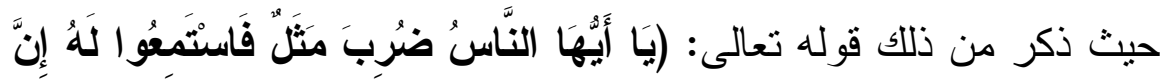

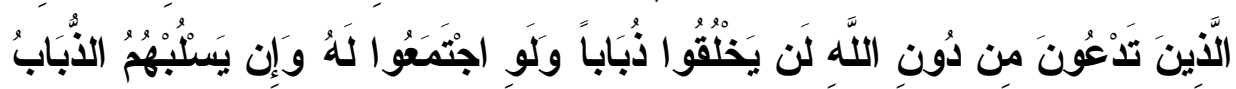

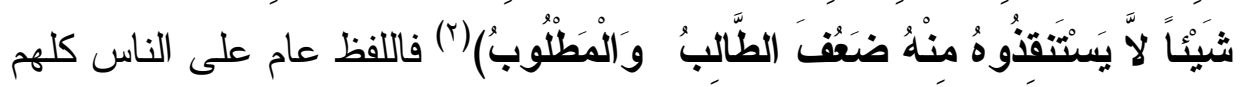
لكنه عند أهل العلم ير اد به بعض الناس دون بعض لأنه لا يخاطب بهذا إلا من

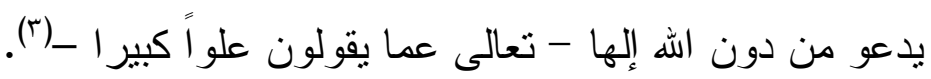

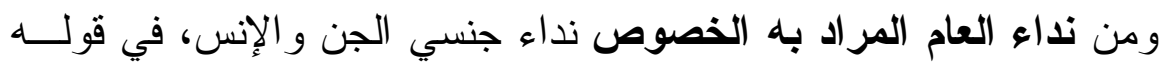

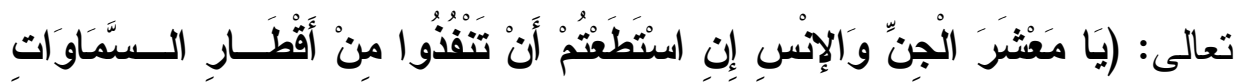

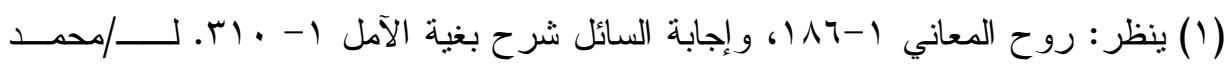

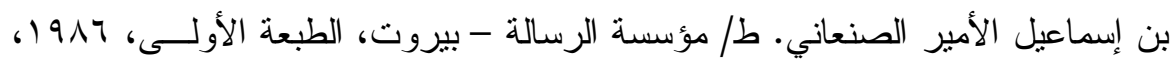

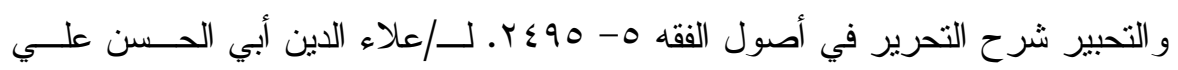

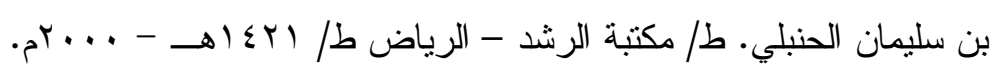

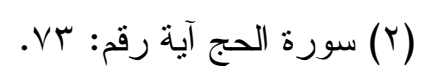

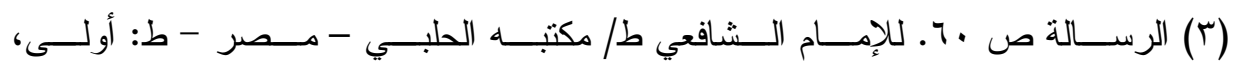

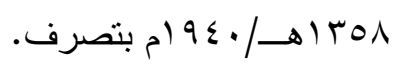




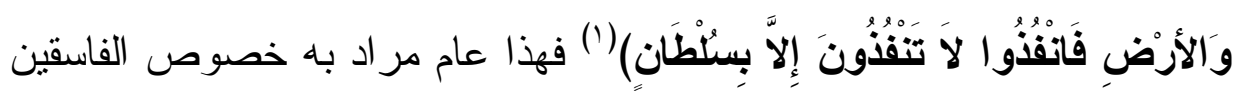

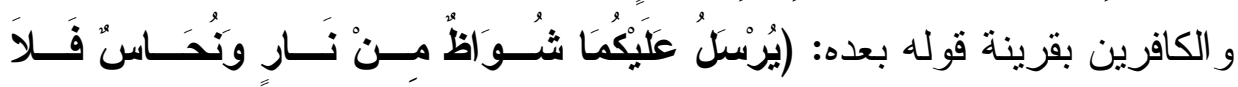

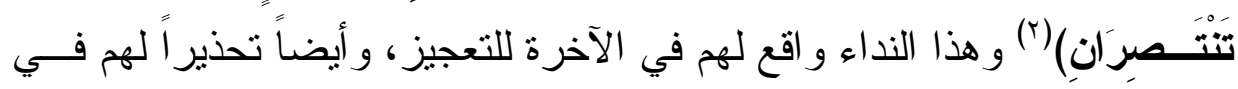

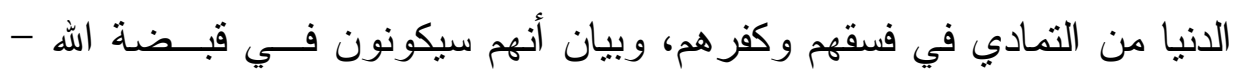
تعالى - وتحت سلطانه...(r). ومن الجائز أن يكون هذا النداء في الانيا لجميع الإنس و الجن على اعنبار تصوير "ضآلة قدر اتهما مجتمعين أمام طلاقة القدرة الإلهية في إبــداع الكــون،

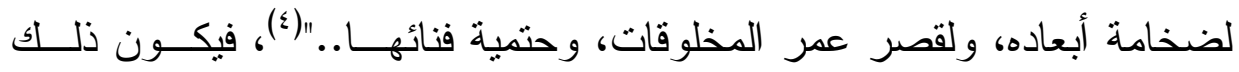

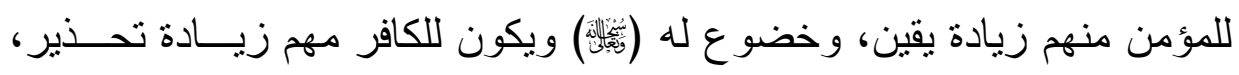
وتعجيز ..

ومن ندائهما على سبيل الخصوص ما ورد في قوله تعالى : (يَا مَعْشَرَ الْجِنِّ

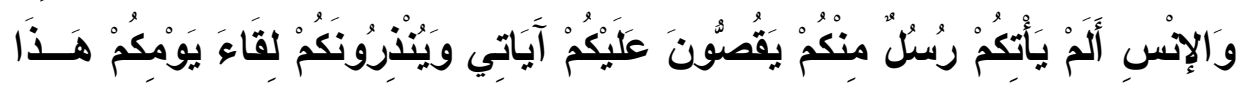

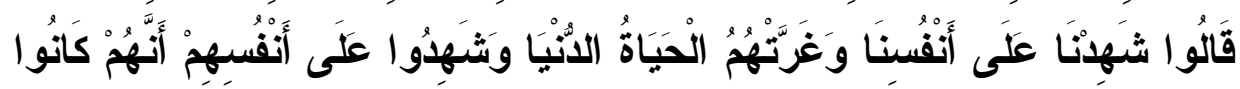

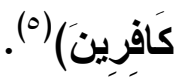

$$
\text { (Y) سورة الرحمن آية رقم: سب. }
$$

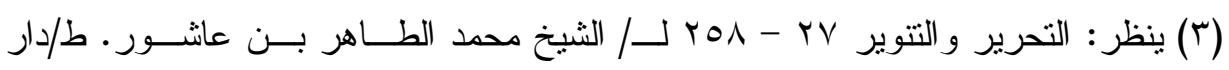

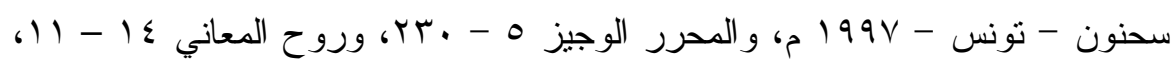

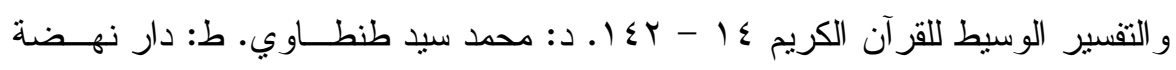

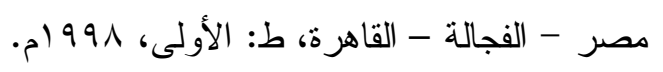

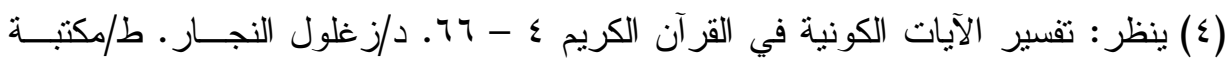

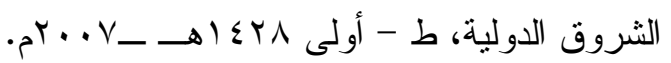

$$
\begin{aligned}
& \text { (0) سورة الأنعام آية رقم: • با. }
\end{aligned}
$$


فالمر اد بالجن و الإنس في الآية الكريمة: العادلين به من مـشركي الإنـس و الجن وندائهما.

في هذا الموقف على سبيل التقريع و التوبيخ ('). ومن نداء جنس الجن في الآخرة على سبيل الخصوص ما ورد في قوله -

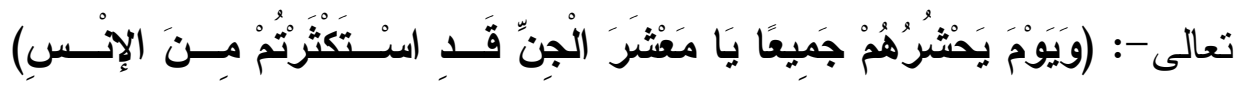

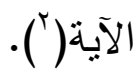

فالمقصود بنداء معشر الجن: الأشرار منهم وهم الثياطين الذين يغــوون

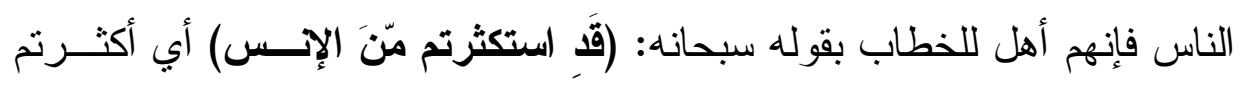
من إغو ائهم و إضلالكهم.

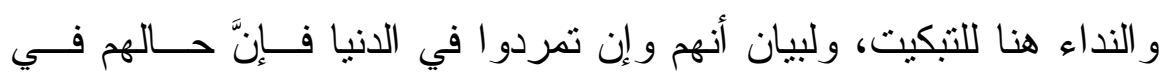
الآخرة ينتهي إلى الاستسلام و الانقياد و الاعتر اف بالجرم (r). ومن نداء الناس ما يرد بلفظ الواحد، و المقصود به العموم كالنداء في قوله

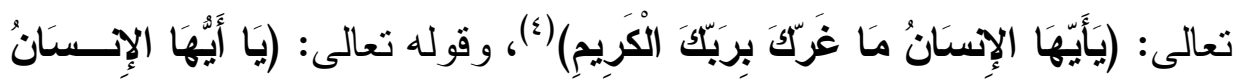

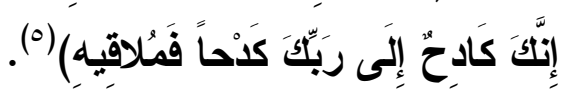

و النداء بـــا "يا أيها الإنسان "للنتبيه، و استدعاء معاني الإنسانية التي أودعها

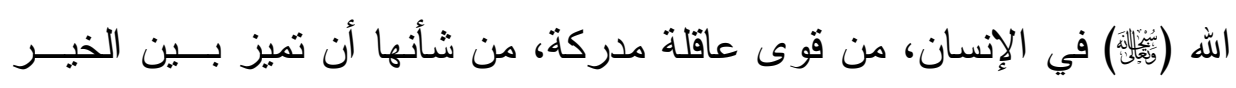

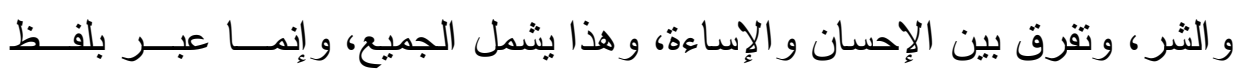

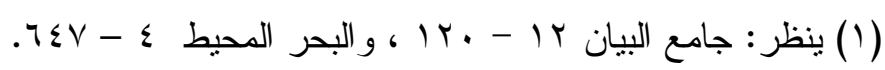

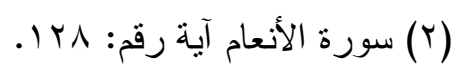

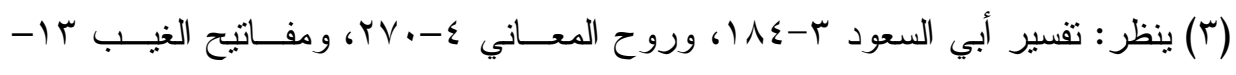

$$
\text { (؛) سورة الانفطار آية رقم: } 7 .
$$


الو احد لأنَّه قائم مقام التتصيص على مخاطبة كل و احد منهم على التعبين وذلك لبيان مسئولية كل فرد عن نفسه بخلاف اللفظ العامّ(').

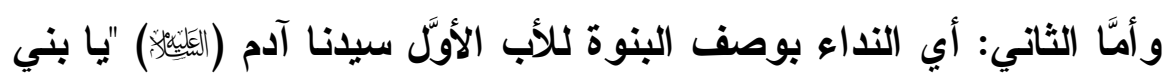

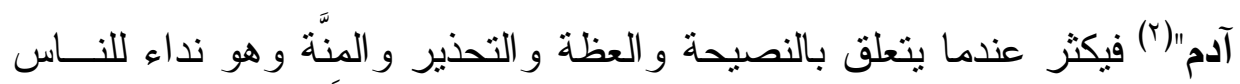
كافة..

وقد ورد هذا النداء في خمسة مو اضع من القرآن الكريم، أربع منهـــا فــي

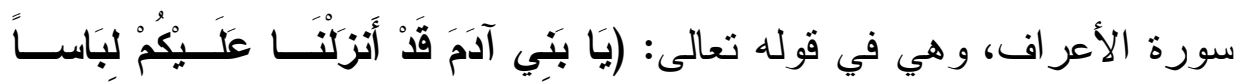

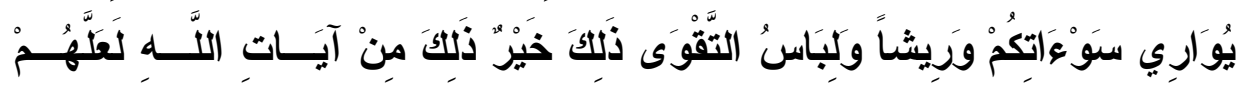

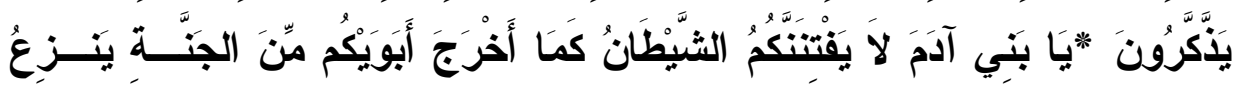

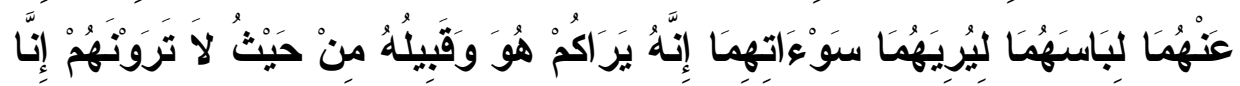

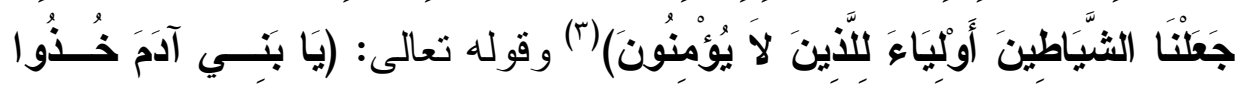

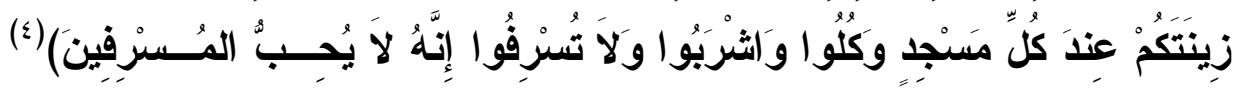

(1) ينظر :، التفسير القرآني للقر آن 17 - . ــ 1 ـ د - عبد الكريم يونس الخطيــب. ط/دار

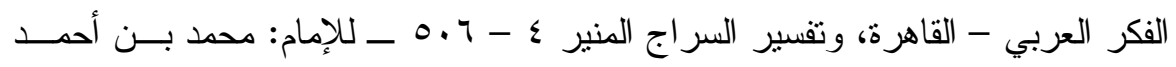

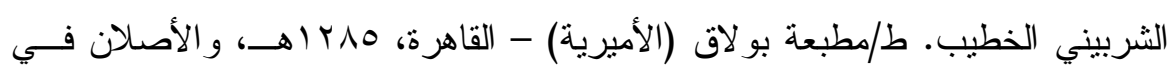

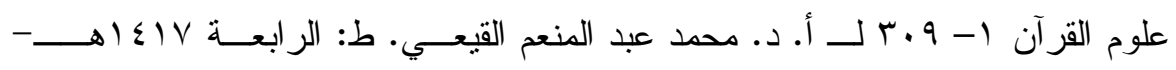

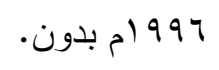

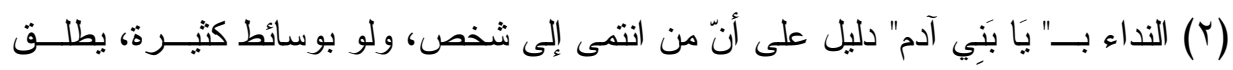

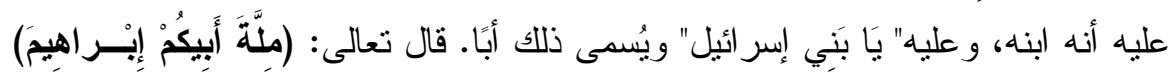

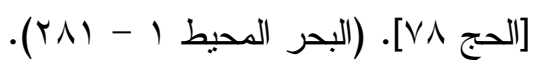

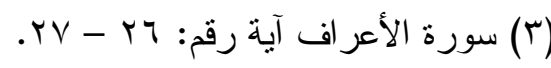

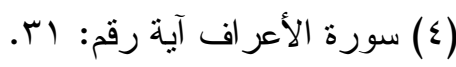




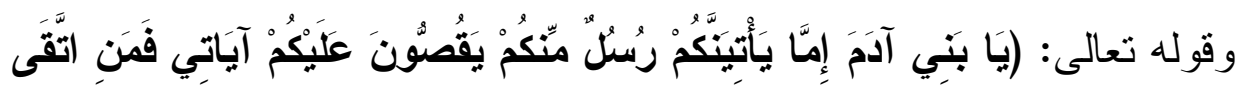

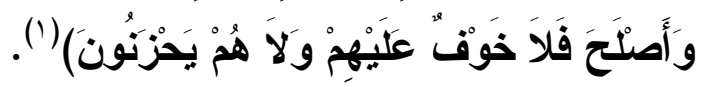

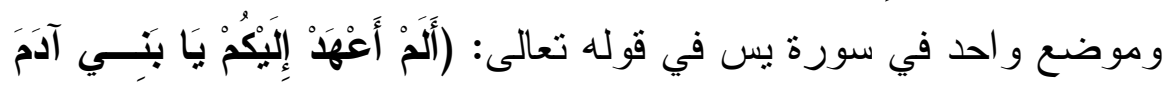

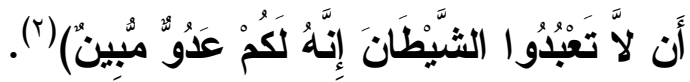

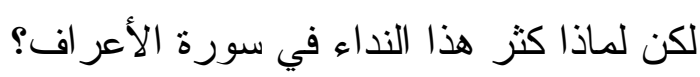

ولمعرفة ذلك ننظر في سياق الآيات التي ورد فيها النداء بــيَا بَنــي آدَم"، حيث نجد أن هذه النداءات جاءت منو الية بعد الحديث عن قـصة آدم وزوجــه

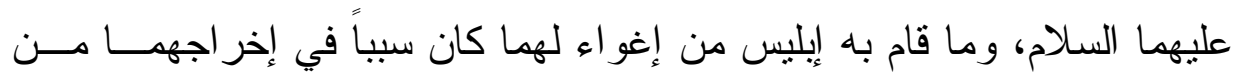

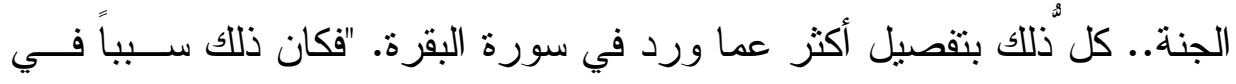

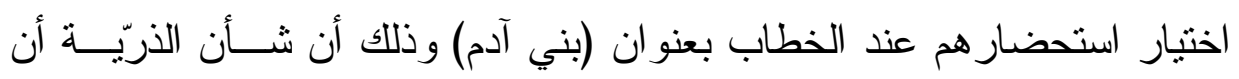
تثأر لآبائها، وتعادي عدوّهم، وتحترس من الوقوع في شَرَكه"(؟).

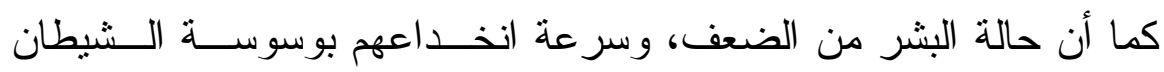

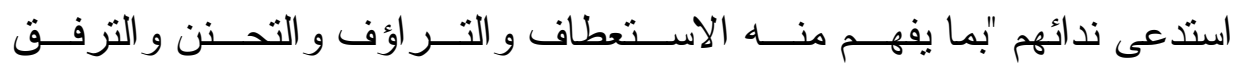
و الاستضعاف: (يا بني آدم)"(؛) ليكونو ابتلك النصيحة على حذر من عدو هم. و هذا شأن الناصحين المقبلين بشفقتهم على المنصوح من استخدام منل هذا

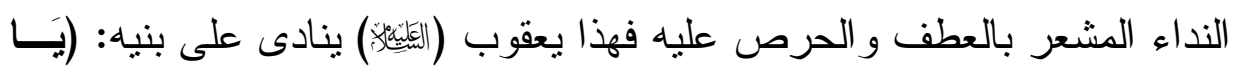

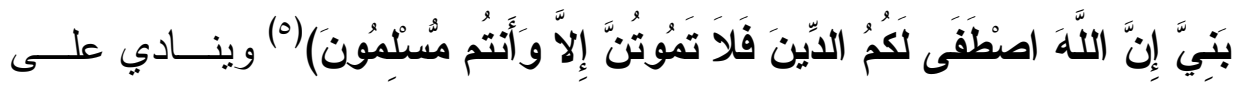

$$
\begin{aligned}
& \text { (1) سورة الأعر اف آية رقم: هب. }
\end{aligned}
$$

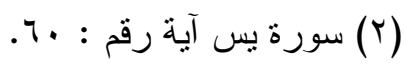

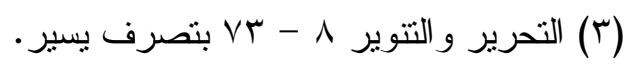

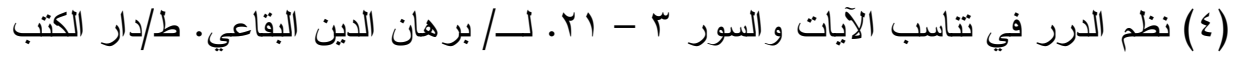

$$
\begin{aligned}
& \text { العلمية - بيروت - إ) اهـ الهـ - } 990 \text { ام. } \\
& \text { (0) سور البقرة آية رقم: بسا. }
\end{aligned}
$$




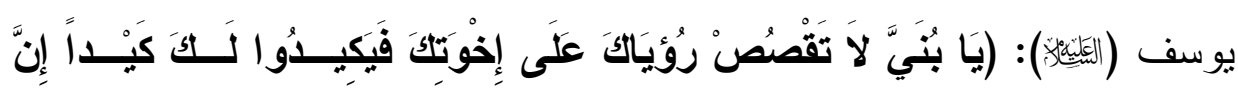

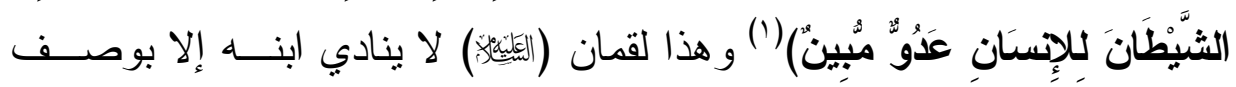

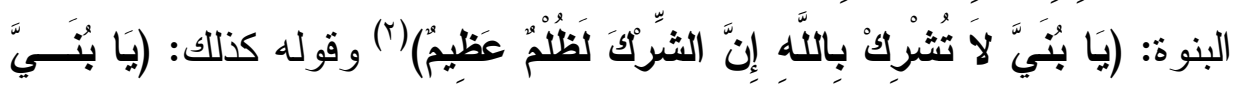

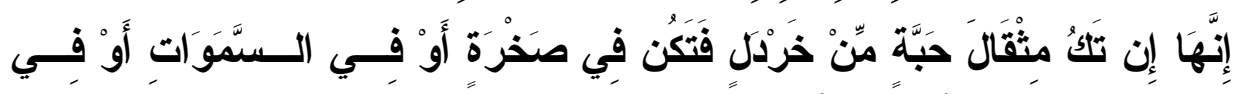

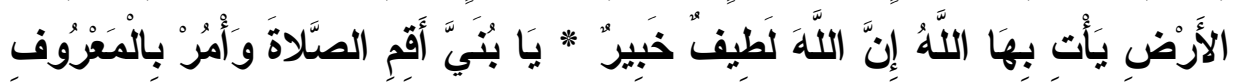

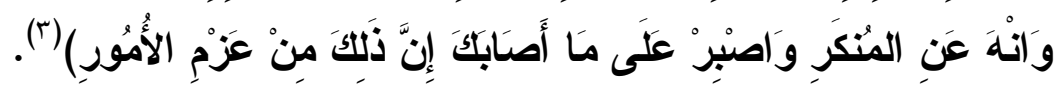

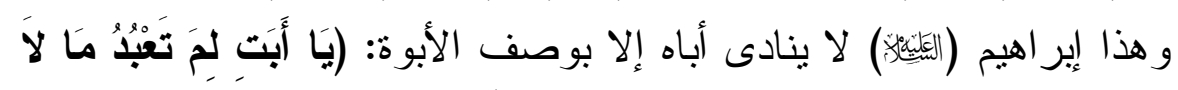

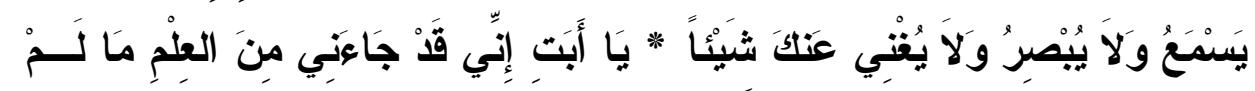

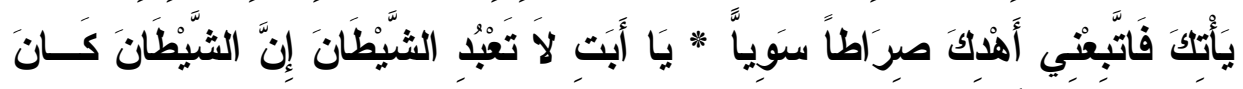

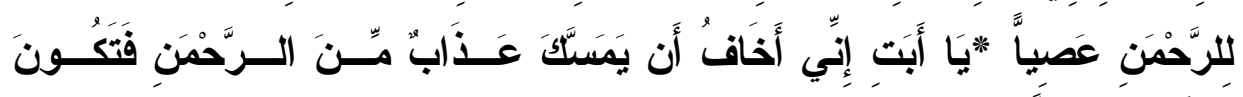

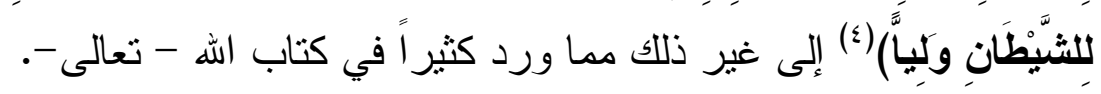

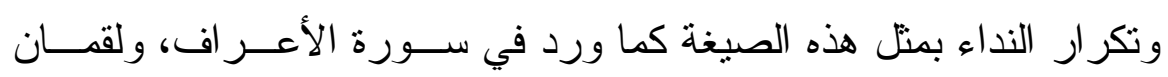

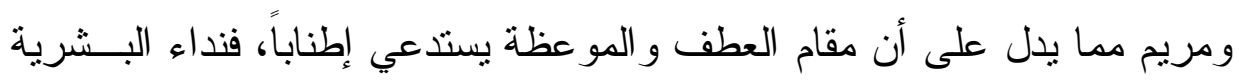

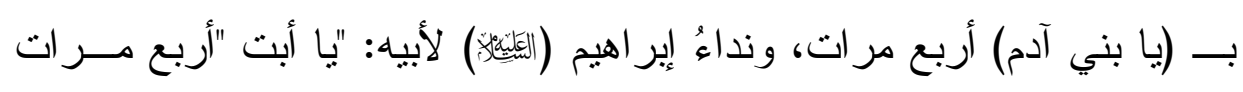

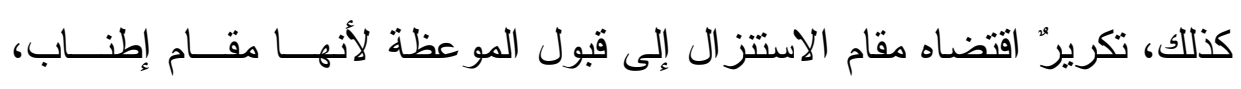

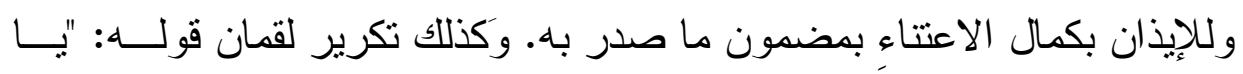

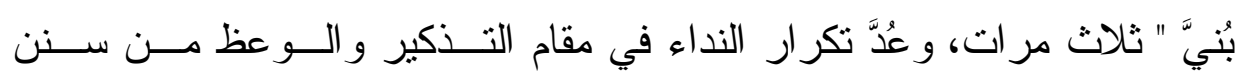

$$
\begin{aligned}
& \text { (1) سورة يوسف آية رقم } 0 .
\end{aligned}
$$

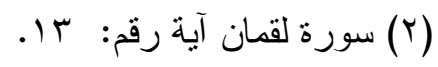

$$
\begin{aligned}
& \text { (Y) سورة لقمان آية رقم: } 17 \text { - IV (Y) }
\end{aligned}
$$

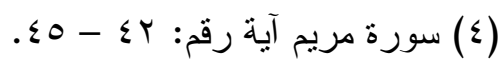


العربية، بخلاف قول نوح لابنه: (يَا بَنَيَّ اركَبَ مَّعَنَـا)(') مرة و احدة دون تكرير

لأنّ ضيق المقام يقتضي الإيجاز وهذا من طرق الإعجاز (r). و أما عن الموضع الخامس الذي ورد فيه النداء بــيا بني آدم "أبي في قوله

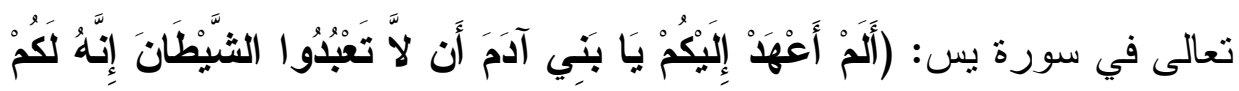

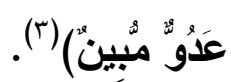
فهو في سياق الحديث عن يوم القيامة وما فيه من ثواب للمطيعين، و عذاب

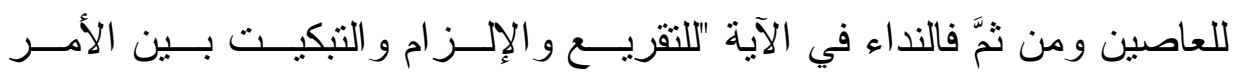

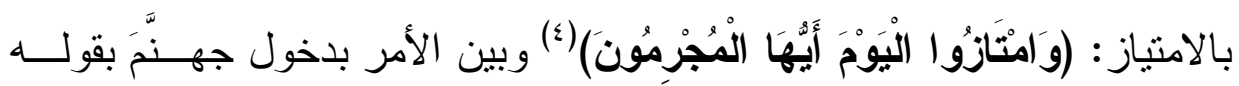

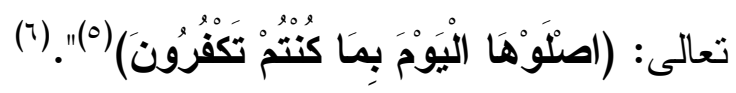
وبذلك تتتظم المو اضع الأربعة الواردة في سورة الأعر اف مــن الوصــية

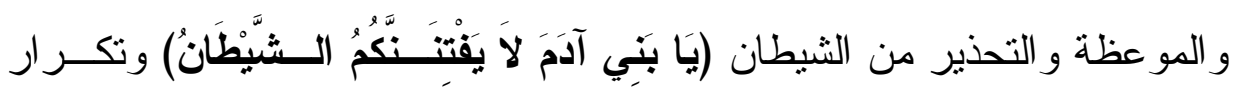
النداء، مع الموضع الخامس الذي ضيع فيه من ضيع هذه الوصية وبنفس النداء

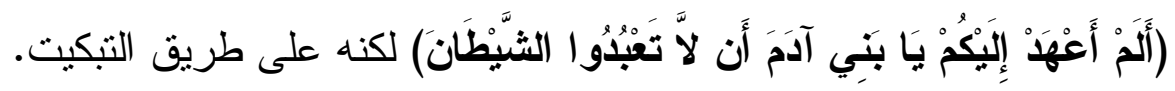

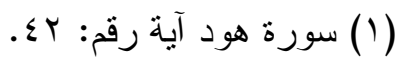

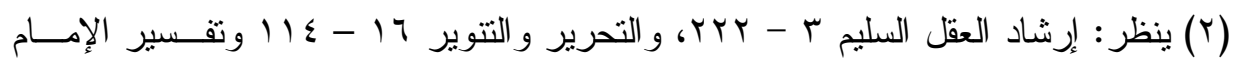

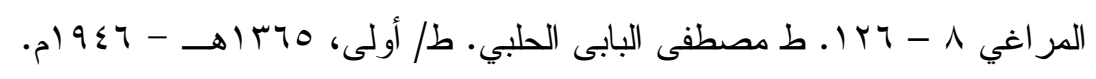

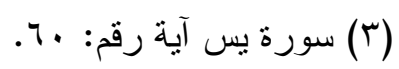
(ع) سورة بس آية رقم:

.

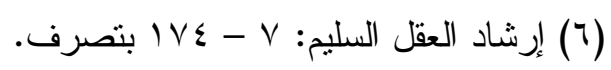




\section{الإلبب الثاني

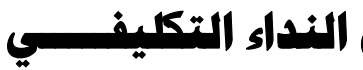

\section{ند|ء الثموبع ويسلمه أيضاً ند|ء النسبة'(').}

نادى الله (ثَيَّل) على طو ائف من البشر ونادى على بني إسر ائيل، وذالك في

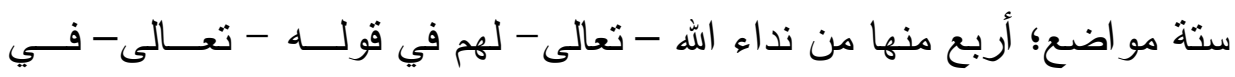

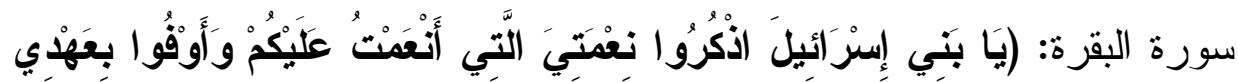

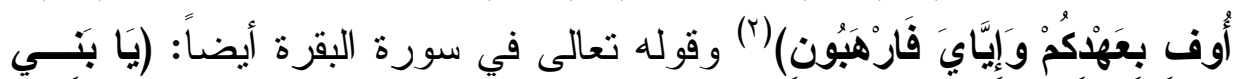

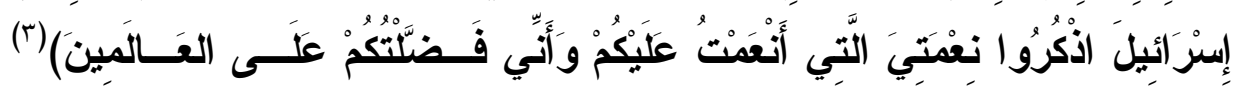
وتكرر هذا النداء في الآية رقمة: r r ا من ذات السورة الكريمة.

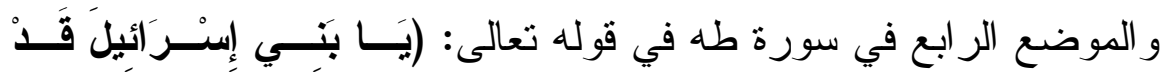

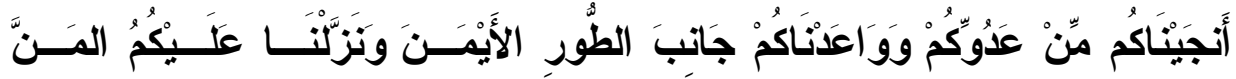

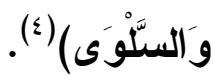

وتكر ار نداء الله - تعالى - لهم إنما هو "للتأكيد و التــذكير بــالنعم، ومنهـــا

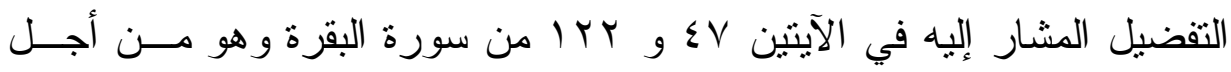

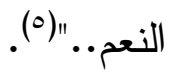

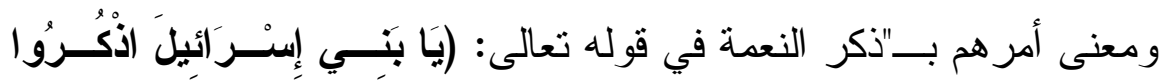

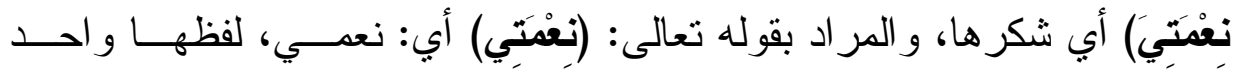

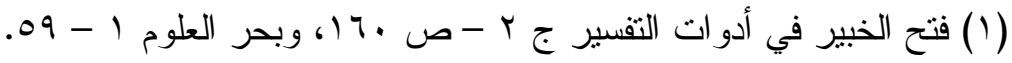

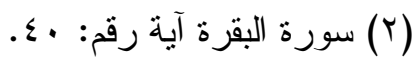

$$
\begin{aligned}
& \text { (r) سورة البقرة آية رقم: V乏. }
\end{aligned}
$$

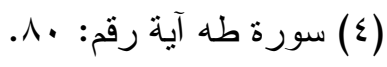

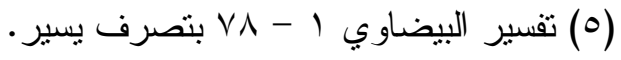


ومعناها جمع كقوله تعالى: (وَإِنْ تَعَدُوُ انِعْمَةَ اللَّهِهِ لاَ تُحْصُوهَا)(') ومن تللك النعم عليهز: فلق البحر و إنجائهم من فرعون بإغر اقه وتظليل الغمام عليهح في التيـــه،

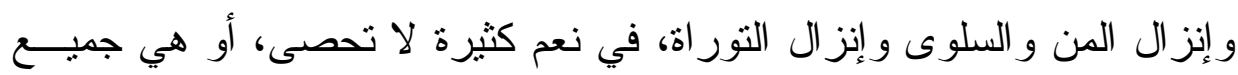

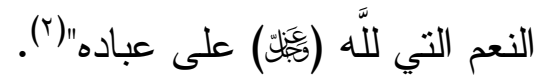

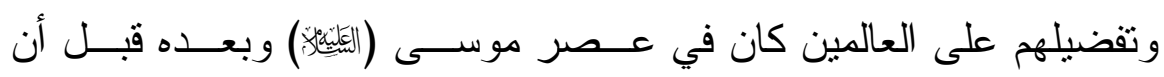

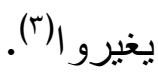

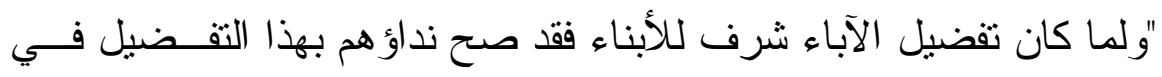

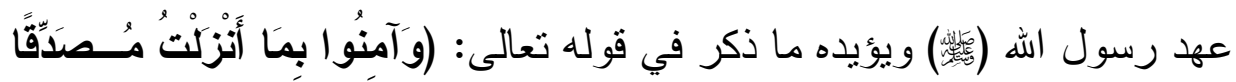

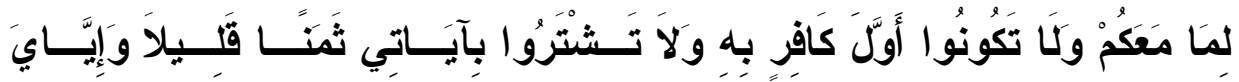

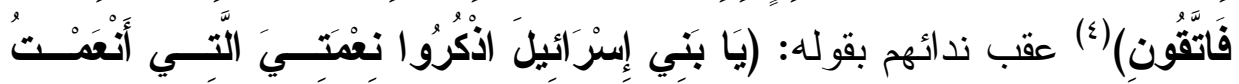

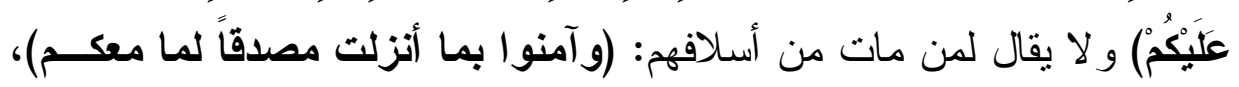
إذ نزول القر آن المصدق لما معهم لم يكن في عهد أسلافهم" (ه).

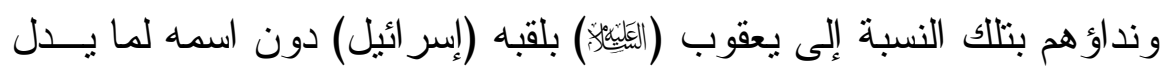
عليه هذا اللقب من دلالات العبودية لله - تعالى - حيث إن هذا اللقــب "مركــب

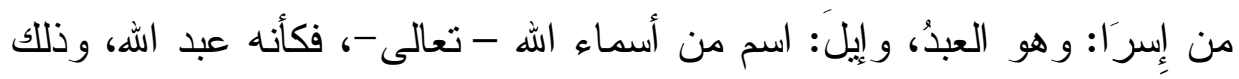

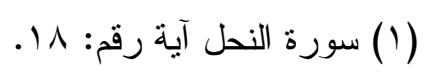

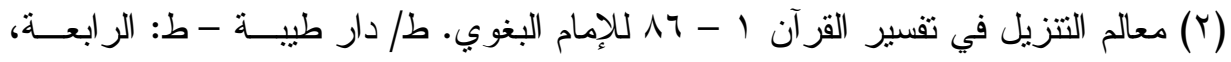

$$
\begin{aligned}
& \text {. } 199 V-\rightarrow \sum 1 V
\end{aligned}
$$

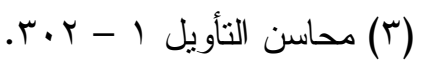

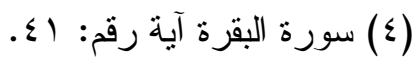

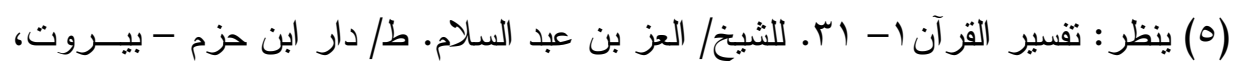

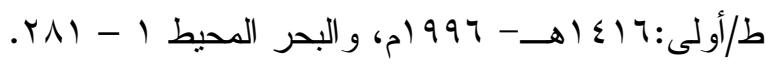


باللسان العبر اني..وقيل: معنى إسر ا: صفوة، و إيـلـل: الله - تعـــالى -، فمعنـــاه: صفوة الله.

فكأنه قيل: يا بني عبد الله، أو يا بني صفوة الله، فكان في ذلك تتبيه علــى

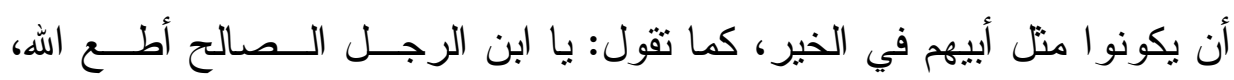
فتضيفه إلى ما يحرّكه لطاعة الله، لأن الإنسان يحبّ أن يقتفي أثز آبائه، و إن لم يكن بذللك محمودًا، فكيف إذا كان محمودًا؟..

فإضافتهم إلى إسر ائيل تشريف، وتهيبجُ لهم بذكر نـسبتهم لهــذا الأصــل

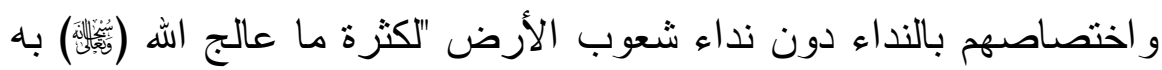
هذا الثعب من النعماء و الضر اء، ثم لم تتفع معهم تللك المعالجة قديماً وحسـديثاً،

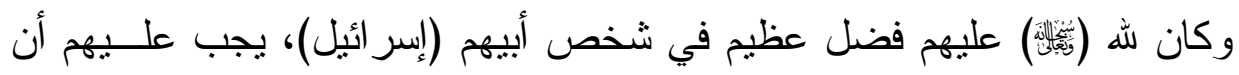
يذكروه وأنْ يقدروه، فيتحولو ا عن موقف المكابرة و العناد إلى موقف الاستجابة و الطاعة (r)".

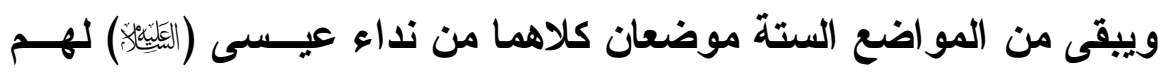

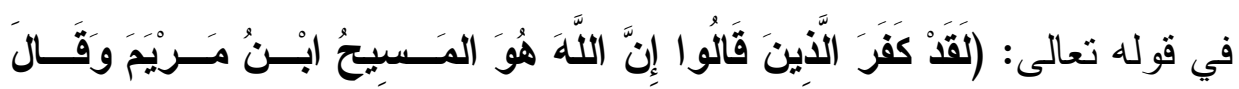

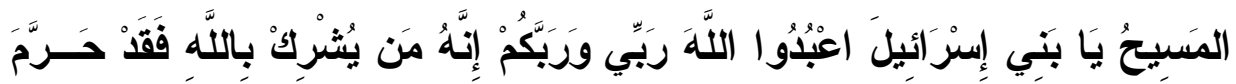

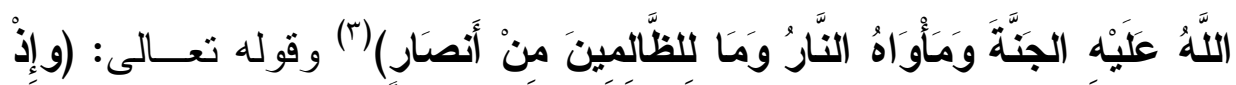

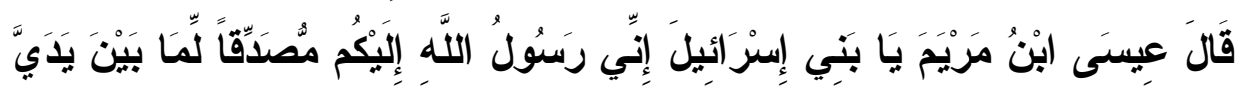

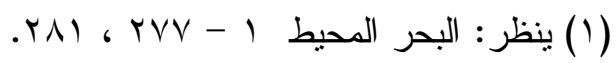

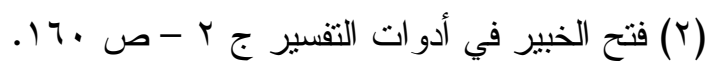

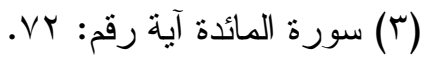




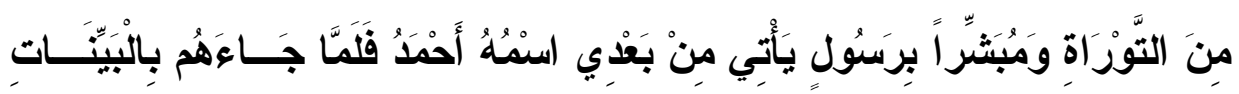

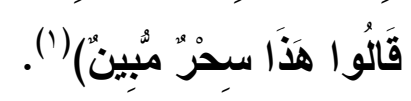

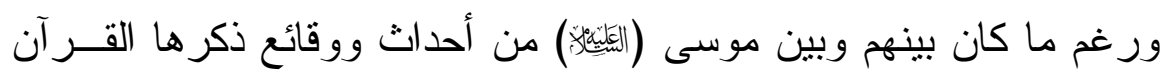

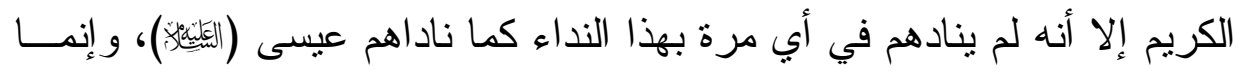
كان يناديهم بـ "يا قوم "فما السرهّ في ذلك؟ للمفسرين تأويلات في هذا الأمر منها:

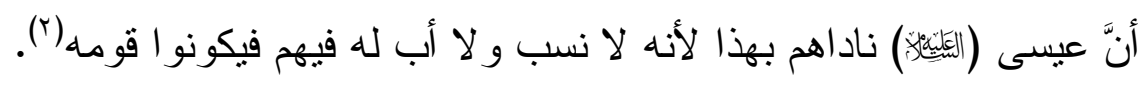

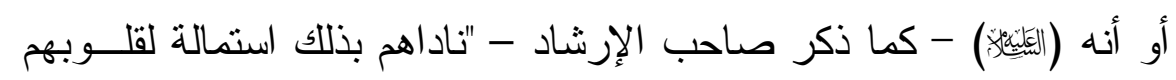

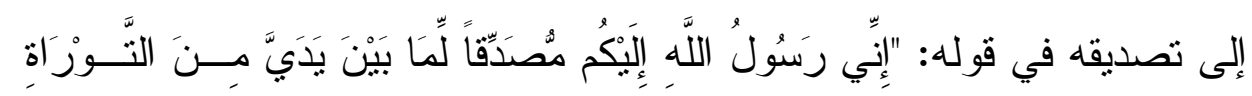

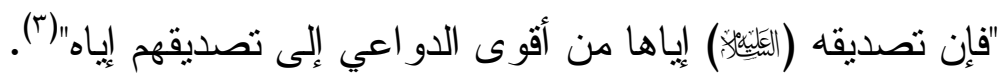

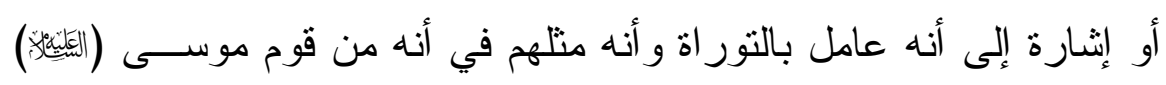
هضماً لنفسه بأنه لا أتباع لله ولا لا قوم (ء). أو"ألن بني إسر ائيل بعد موسى اثتتهرو ا بعنوان (بني إسر ائيل) ولم يطلــق

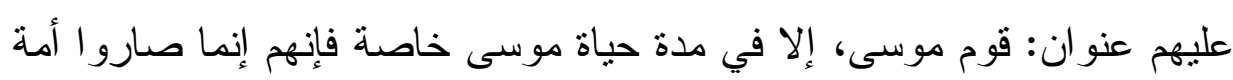
وقوماً بسببه وشريعته.

$$
\text { (1) (1) سورة الصف آية رقم: } 7 .
$$

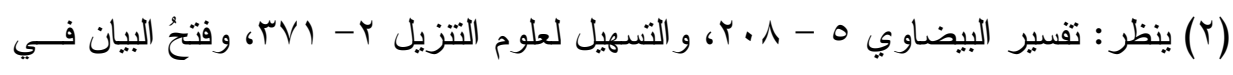

$$
\text { مقاصد القر آن ـ ا - . . 1. }
$$

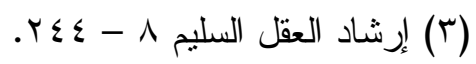

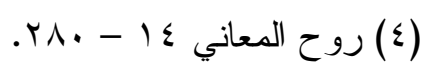


فأما عيسى فإنما كان مرسلاً بتأييد شريعة موسى، و التذكير بهـــا وتغييــر

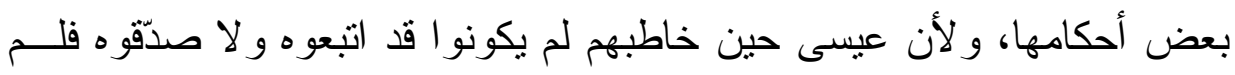

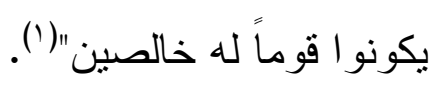

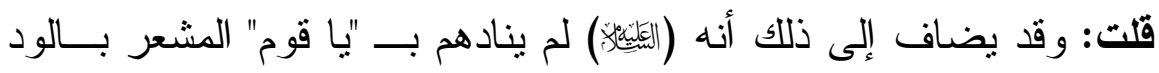

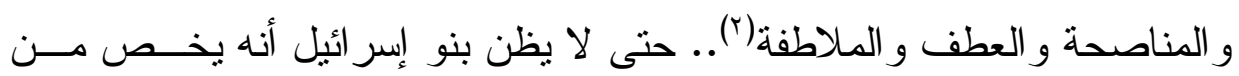

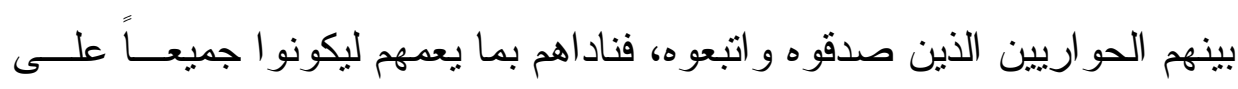
قدر المسئولية تجاه ما ناداهم به من عبادة الله وحده لا شــريك لــه، وبــشر اه

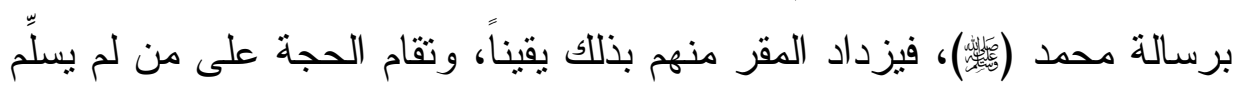
بذلك منهم.

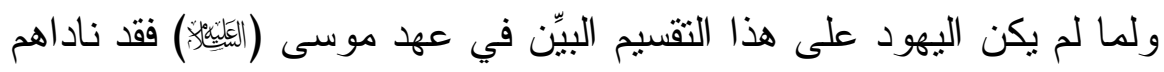

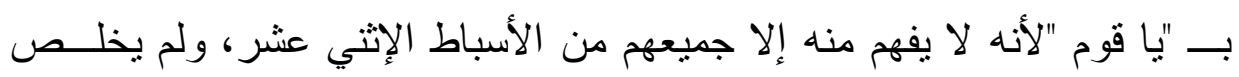

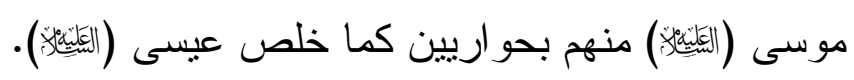

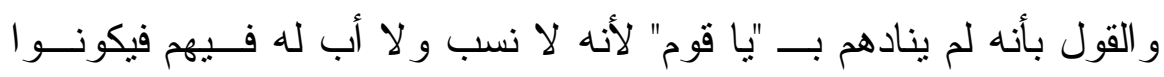

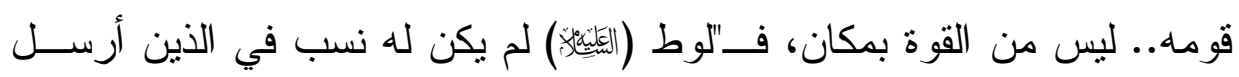

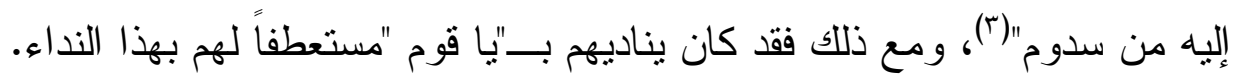
و اله أعلم.

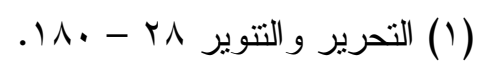

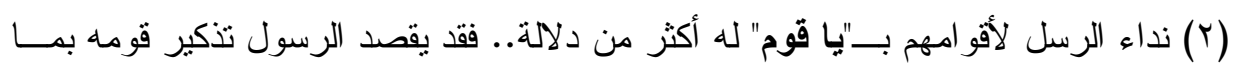

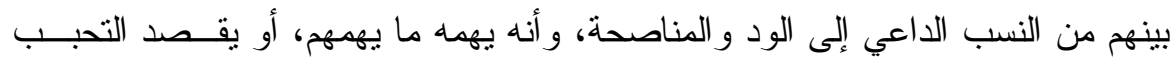

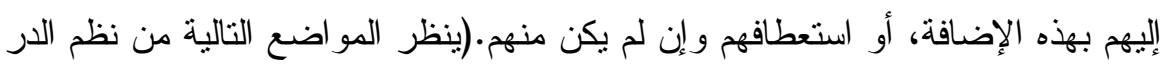

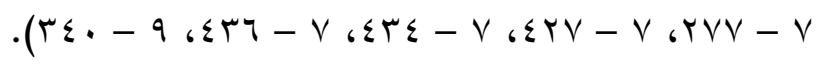

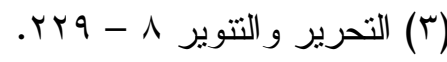




\section{الإطب الثالث}

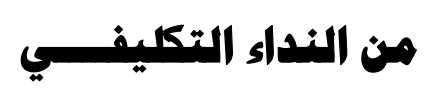

\section{ند|ء الطو|ثئفع(')}

$$
\text { وهذا في القرآن الكريم على نوعين: }
$$

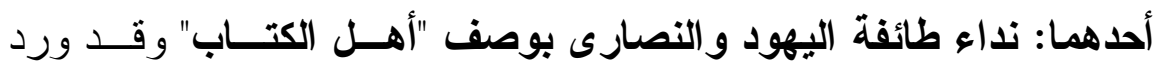

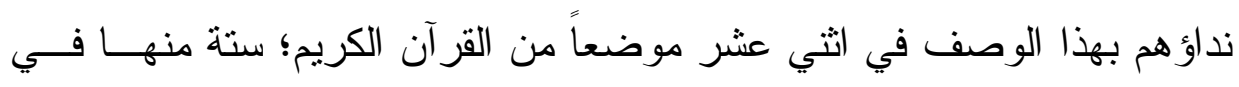
سورة آل عمر ان وموضع واحد في سورة النساء و الخمسة الباقية فـي ســورة فئس المائدة.

ولا يخفى ما في سياق هذه السور الثناث من "ورود الحديث عـن عيـسى

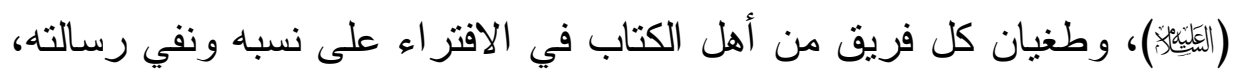

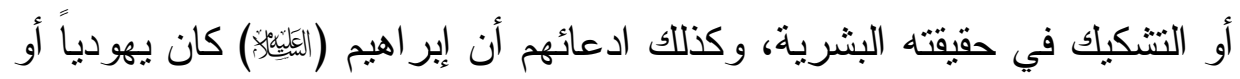

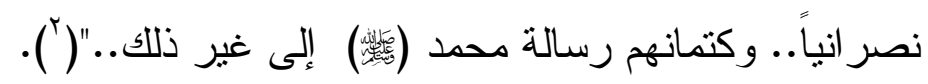

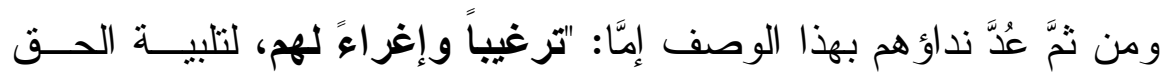

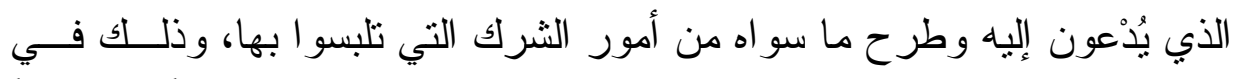

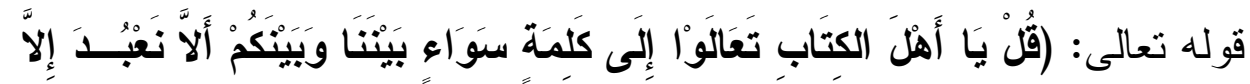

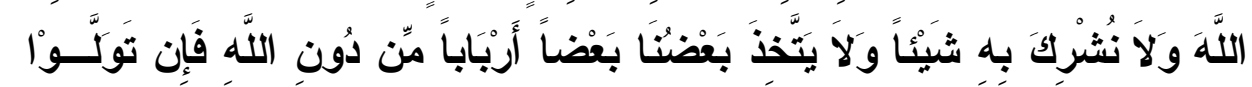

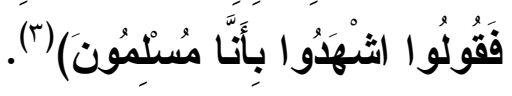

(1) فتح الخبير في أدوات التفسير جr- ص اج1 . ويسميه الإمام الزركثي خطاب النـوع.

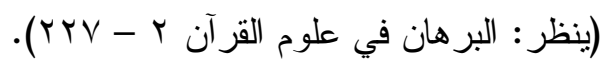

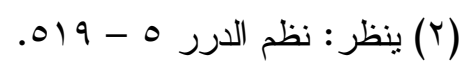

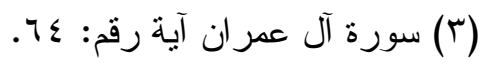




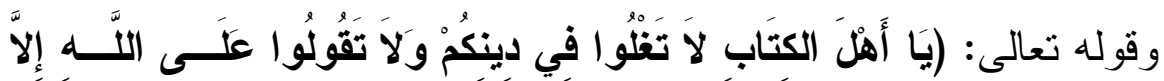

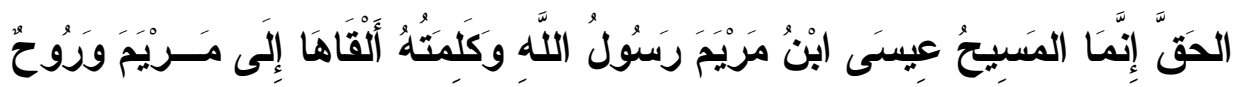

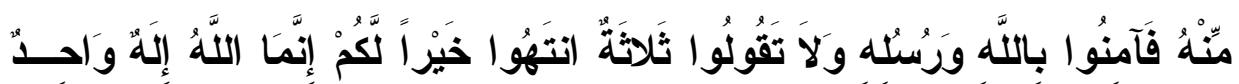

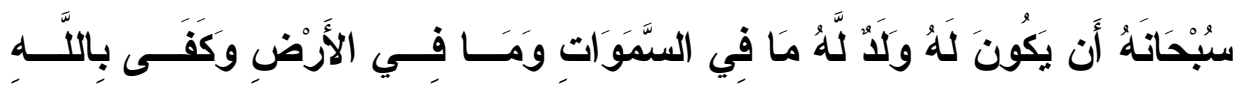
وكيلاً) (')

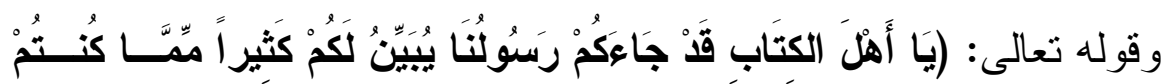

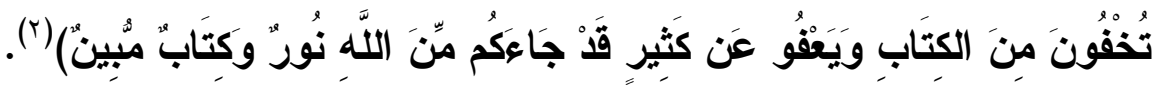

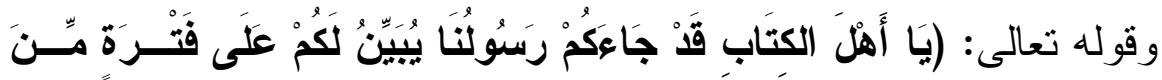

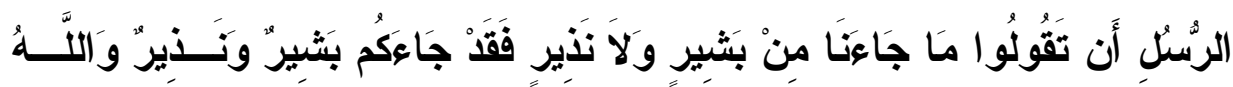

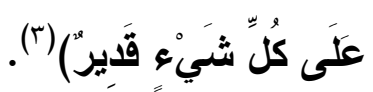
و إما تبكيتاً لهم على ما كانو ا يرتكبون من أفانين التضليل و أنو اع التـشكيك

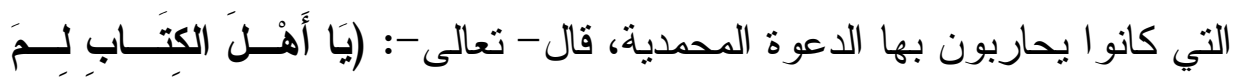

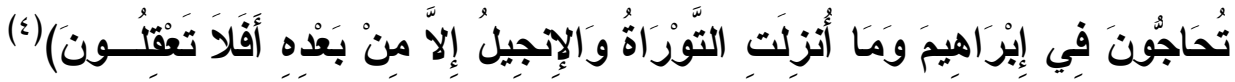

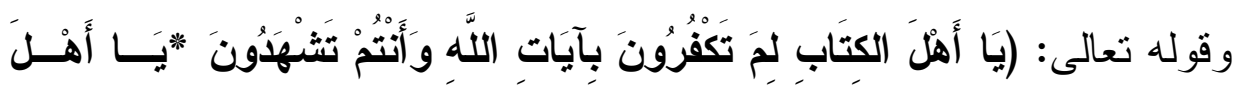

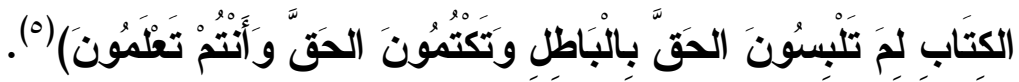

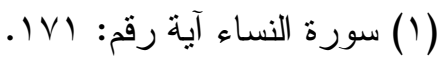

$$
\begin{aligned}
& \text { (Y) سورة المائدة آية رقم: } 10 \text { (Y) } \\
& \text { (T) سورة المائدة آية رقم: } 19 \text {. }
\end{aligned}
$$

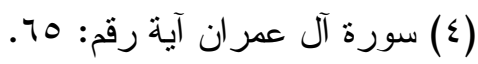

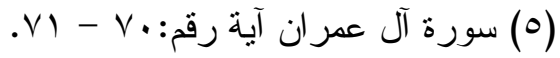




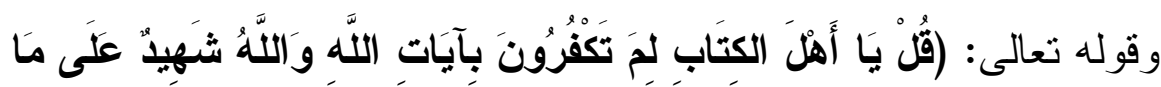

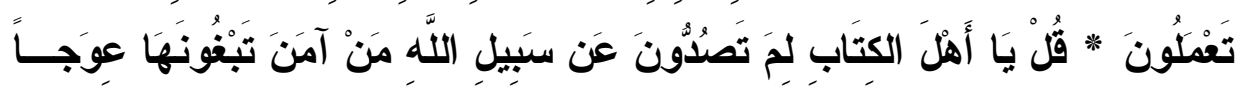

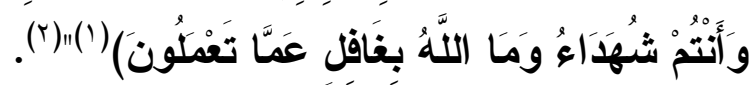

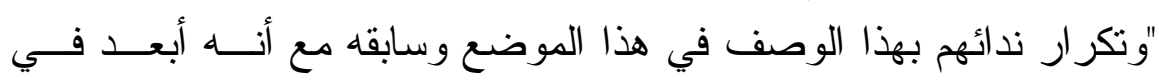

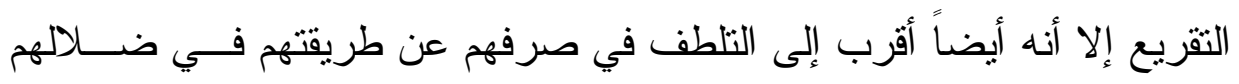
و الإضلال و أدل على النصح لهم في الدين و الإشفاق"(r).

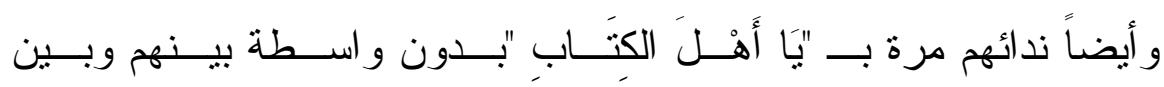

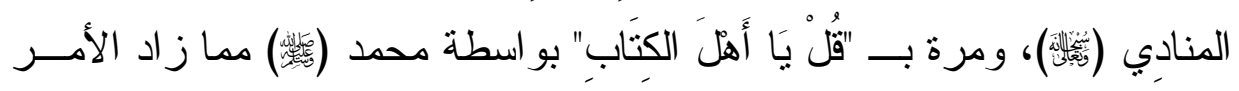
المنادَى من أجله تأكيداً كأنهم نودو ا بكل سبيل، كما أنَّ فيه رفعة لقدر رسول الله (

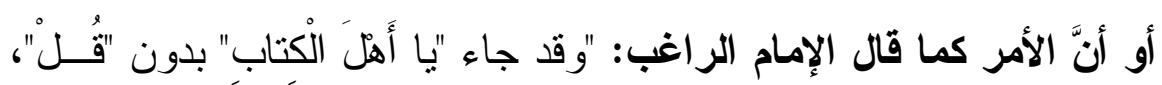

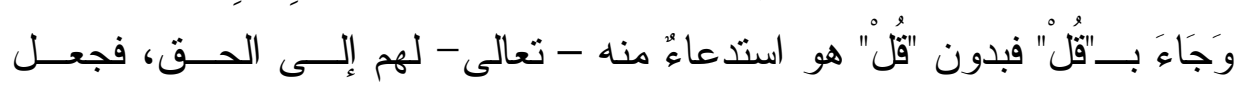

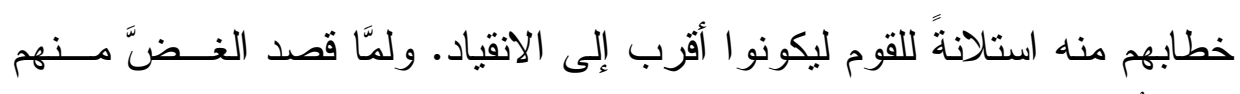

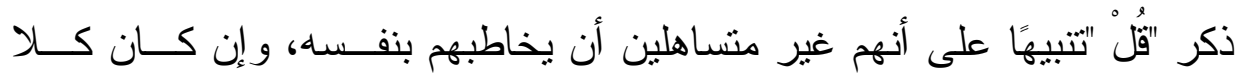

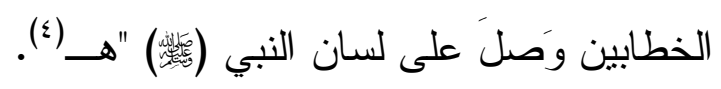

$$
\text { (1) سورة آل عمران آية رقم: } 91 \text { (1) - } 99 .
$$

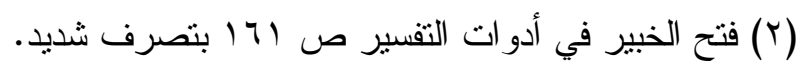

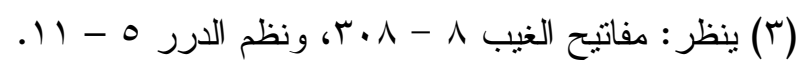

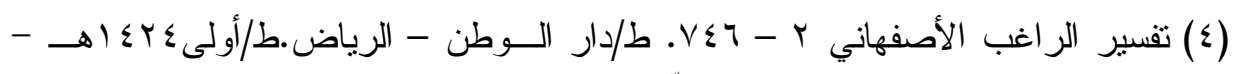

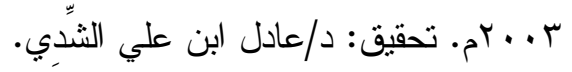




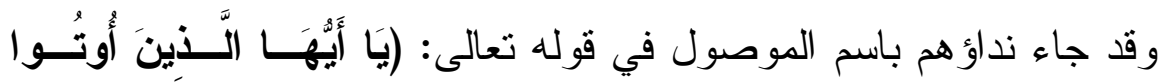

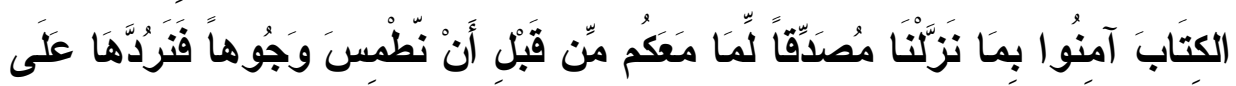

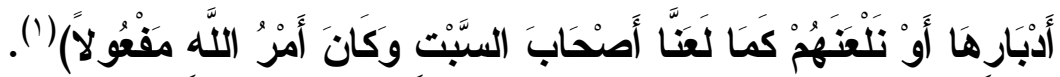
و التهديد الو ارد في هذه الآية الكريمة مما كان سبياً في أن ترد صيغة النداء

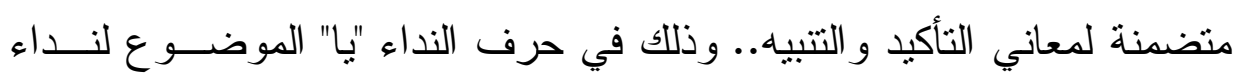

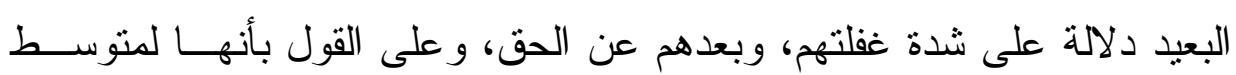

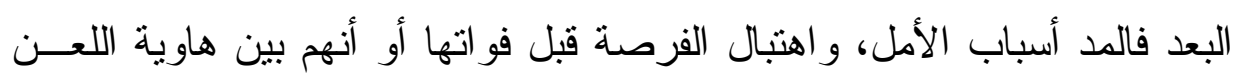
وبين الإيمان المنجي منها.

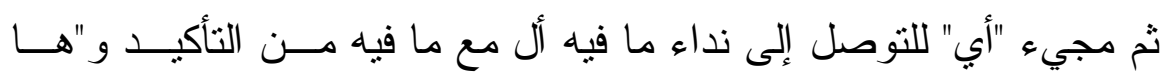
"التتبيه "الدال على معاضدة ومكاتفة حرف النداء لتأكيد معناه..

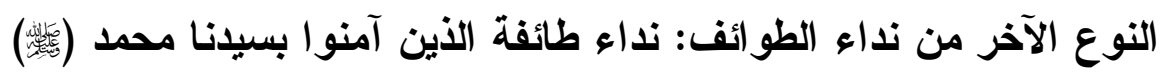

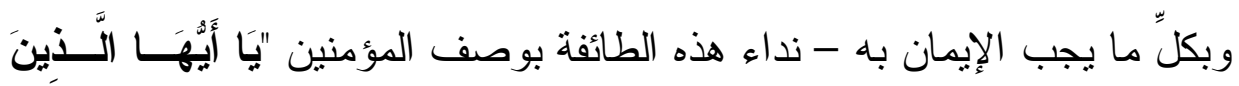

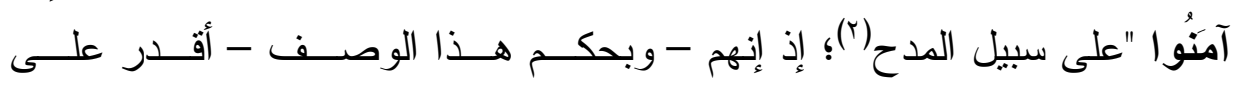
الاستجابة، و امتنال ما طلب منهم، وكلفو ابه. وتتبيهاً في نفس الوقت إلى رفعــة شأنهم و امتداح أمر هم عند ربهم. وقد ورد نداء هذه الطائفة بوصف الإيمان في مو اضع كثيرة مــن القــر آن

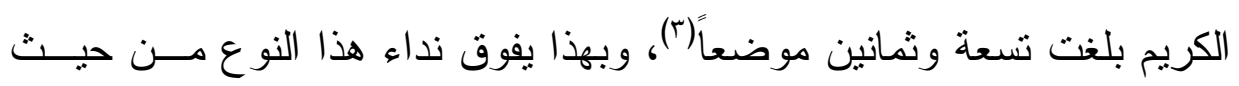

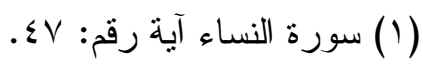

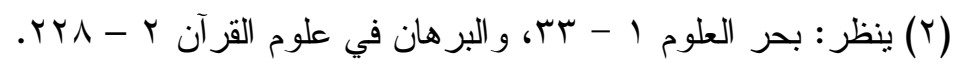

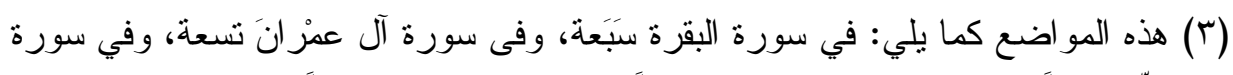

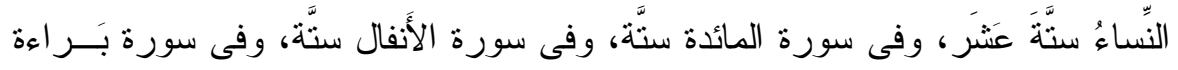

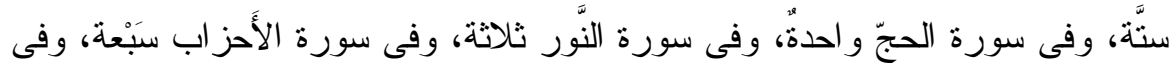

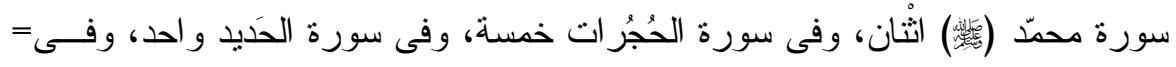


الإحصاء العددي جميع أنواع النداءات الأخرى الوار ادة في القر آن الكريم، مـــا

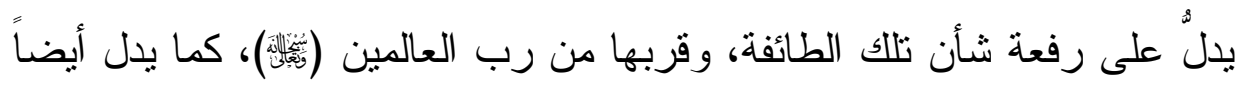

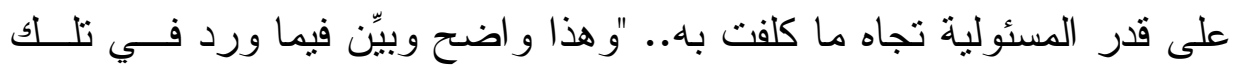

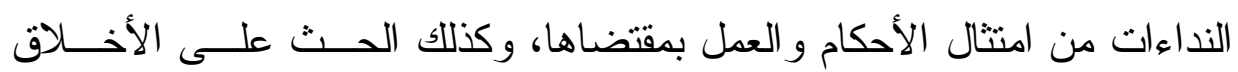

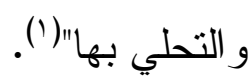

ومن ثمَّ فلهذا النداء أهمية كبرى؛ إذ عليه تبنى جُّلُ التشريعات الإســلامية،

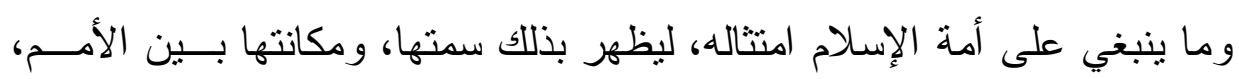

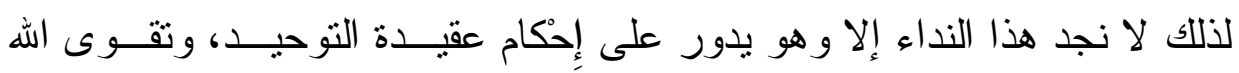

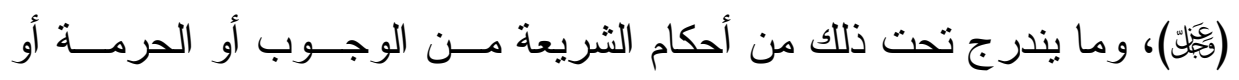
الندب إلى غير ذلك من التكاليف الثر عية، والآداب و الأخلاق الاجتماعية.

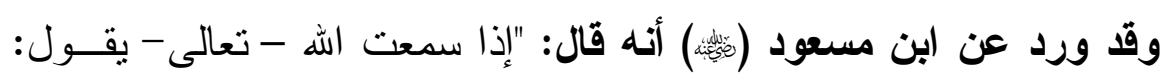

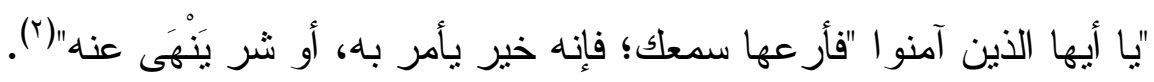

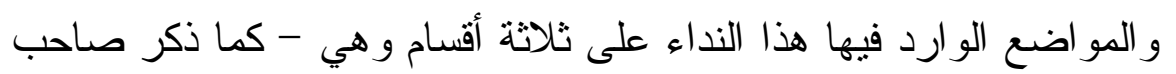

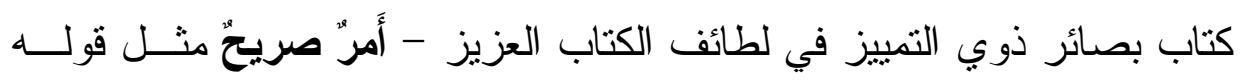

=سورة المُجادلَة ثَلَاثَة، وفى سورة الحَشْر واحد، وفى سورة المُمْتَحَنَة ثَلاثة، وفى سورة

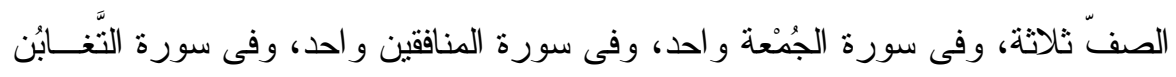
و احد، وفى سورة التَّريم واحد.

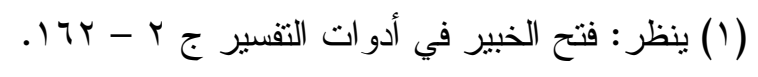

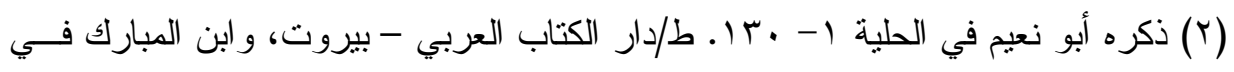

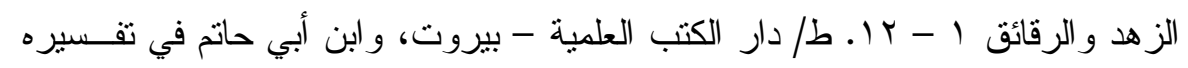

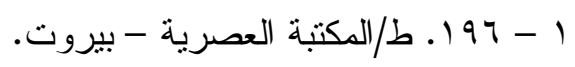




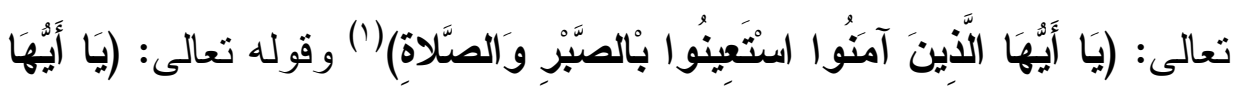

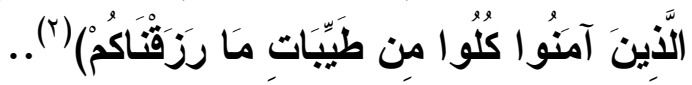

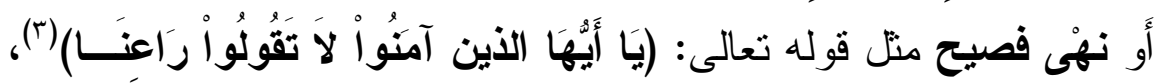

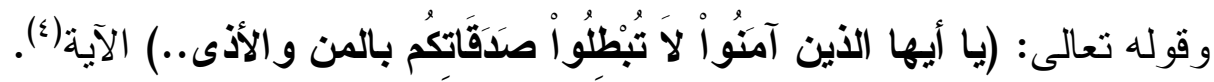

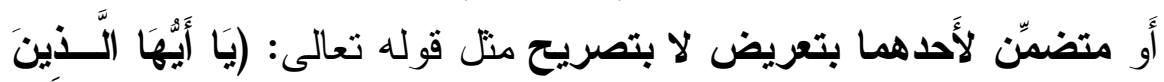

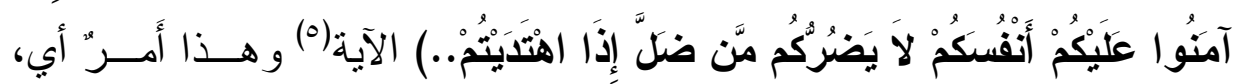

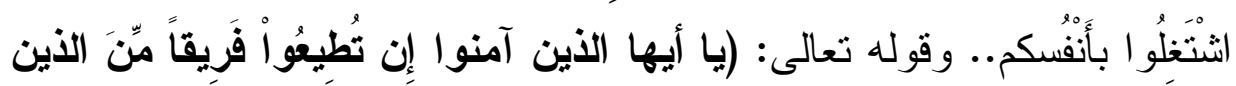

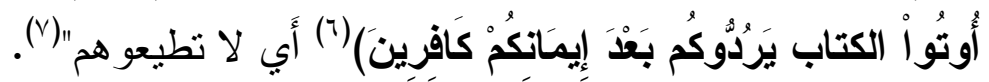

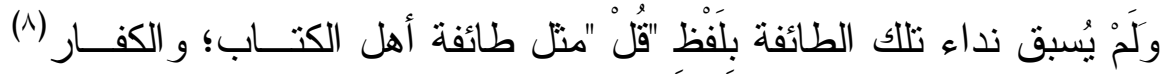

لــ"يكون ذلك خطابًا منه تعالى لهم وتأنيسًا لهم"(9).

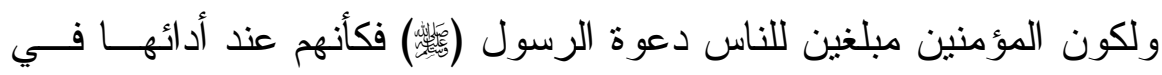
مقام الرسالة التي تتلقى عن الله مباشرة. "وهذا من الخيرية التي تميزت بها هذه الطائفة كما قال تعالى : (كُنتُّ خَيْـرَ

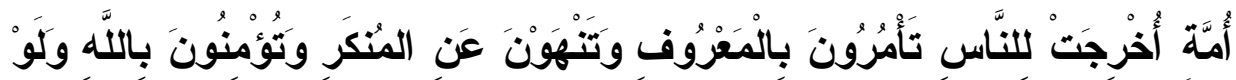

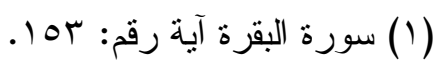

$$
\begin{aligned}
& \text {. IVT: } \\
& \text {.1. } \varepsilon \text { : } \\
& \text {. Yฯะ: } \\
& \text { (0) سورة المائدة آية رقم: } 0 \text { (1) } 1 \text { (1) }
\end{aligned}
$$

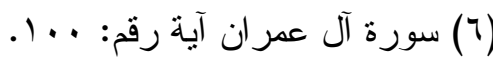

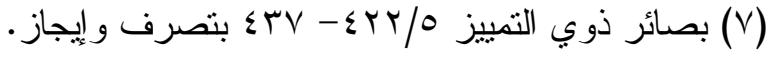

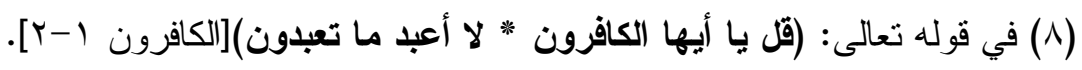

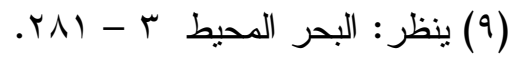




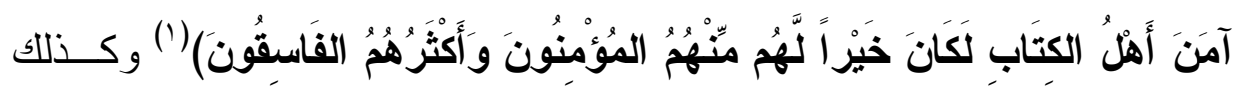

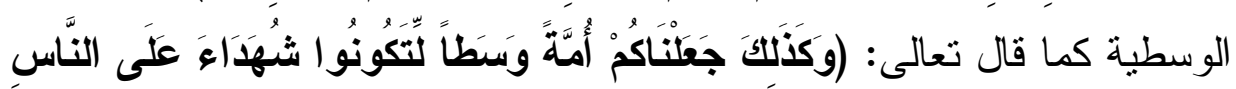

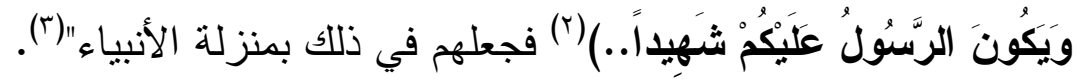

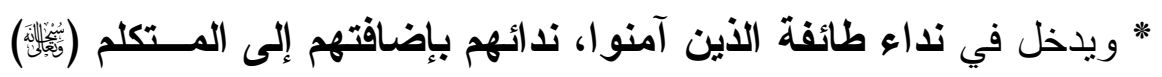

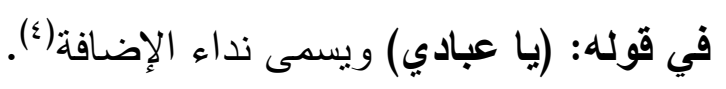

وقد ورد ندائهم بهذه الإضـافة في خمسة مو اضع من القر آن منها ثناثنة فـي

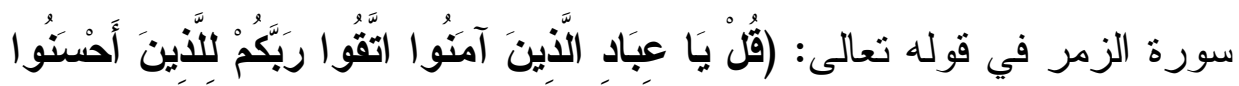

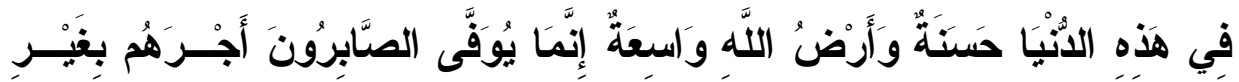

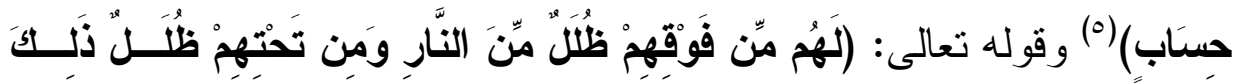

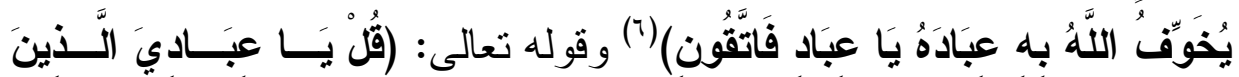

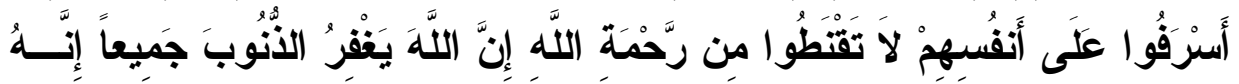

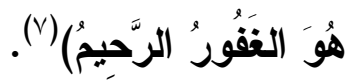

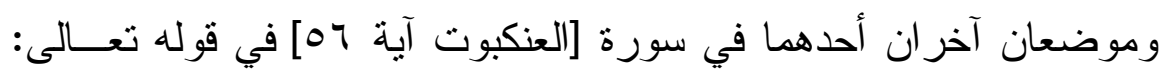

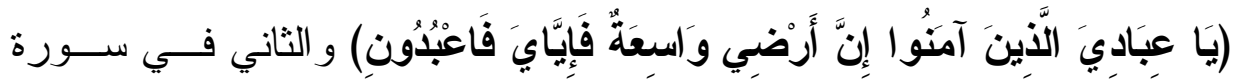

$$
\text { (1) (1) سورة آل عمران آية رقم: .11) }
$$

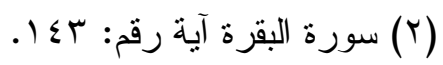

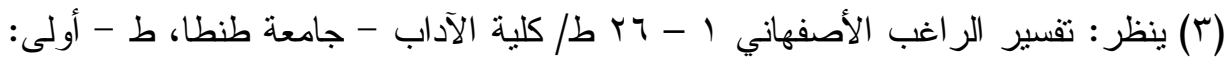

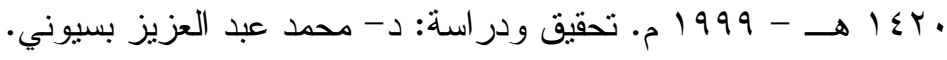

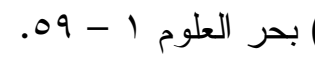

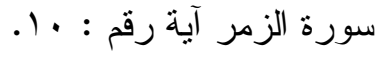

$$
\begin{aligned}
& .17 \text { : } \\
& \text { or : }
\end{aligned}
$$




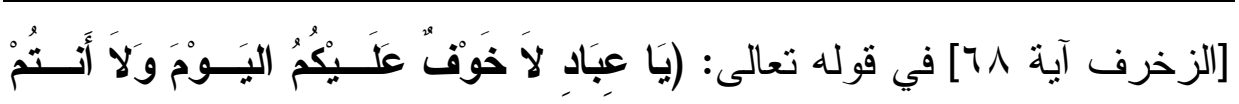
تَحَزْنَونَ).

و لا خلاف في أن المر اد بالعباد في هذه النداءات الخمس هم المؤمنــون إلا الموضع الثاني والثالث من سورة الزمر فقد قال بعض المفسرين: المر اد بالعباد في الموضعين المؤمنون و الكافرون، وذكر بعضهم أن العباد في الموضع الثالث

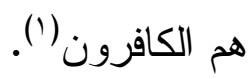

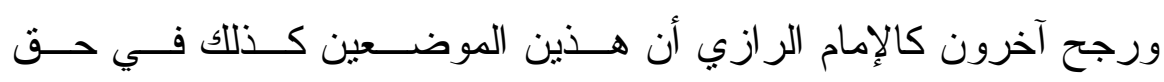
المؤمنين. قال الإمام الرازي مبيناً وجه هذا الترجيح: "عُرف القرآن جار بتخصيص آنَ

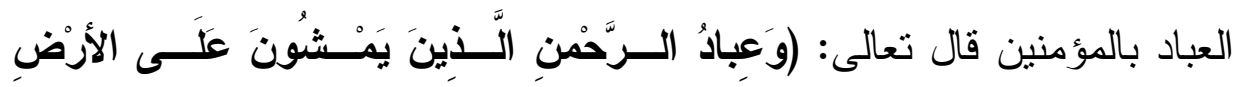

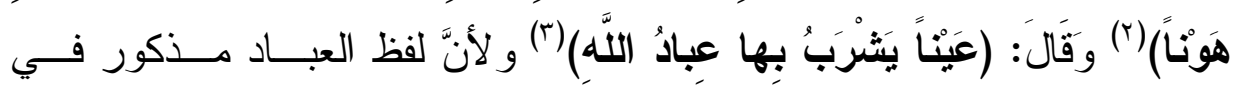

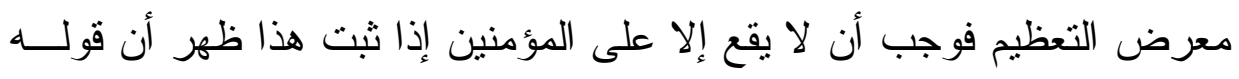

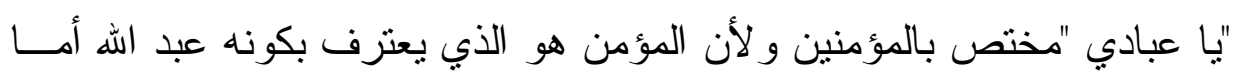
المشركون فإنهم يسمون أنفسهم بعبد اللات و العزى و عبد المسيح فتبت أن قوله لهونه

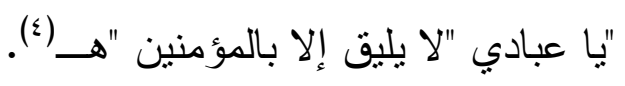

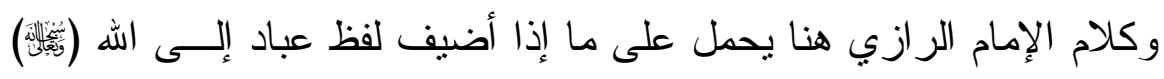

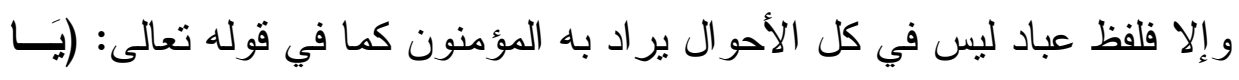
(1) ينظر : بيان المعاني ب - اسه. لــ/ عبد القادر بن ملاً حويش السيد محمود آل غــازي

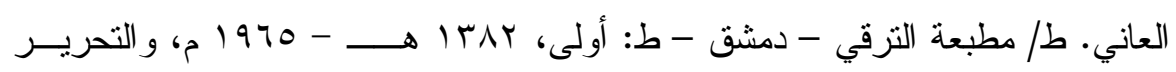

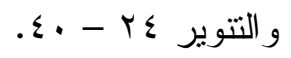

$$
\begin{aligned}
& \text { (Y) سورة الفرقان آية رقم: كائ. } \\
& \text { (Y) سورة الإنسان آية رقم: } 7 .
\end{aligned}
$$

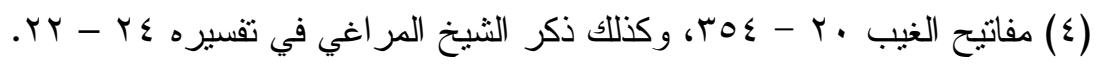




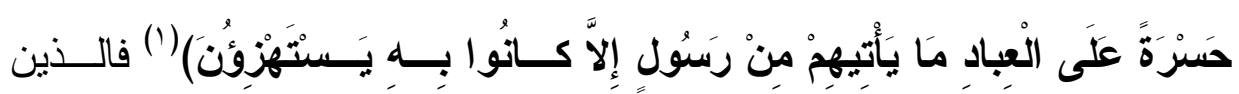
يستهزئون برسل الله ليسو ا بمؤمنين.

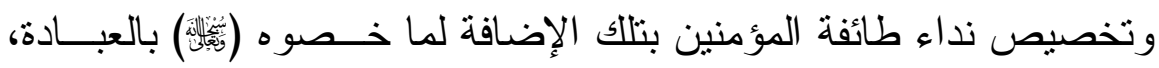

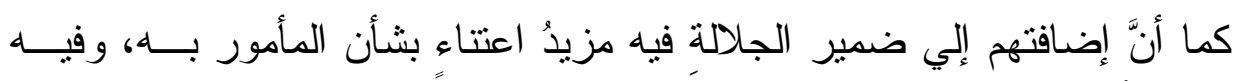

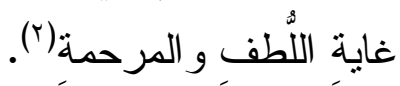
مع ما في حرف النداء من رفعة منزلتهم و الاهتمام بالأمر المنادى من أجله إن كان للبعيد، و على ما ينبخي أن يكونو العليه من رجائه و الخوف منه إن كان لمتوسط البعد.

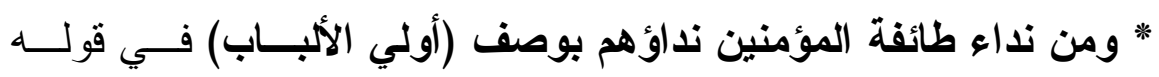

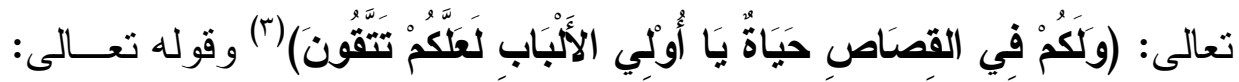

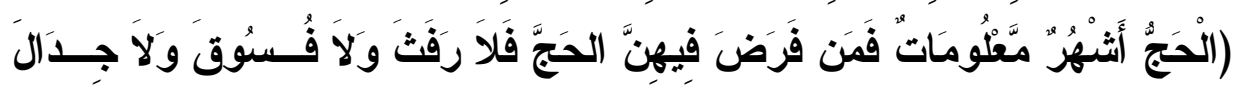

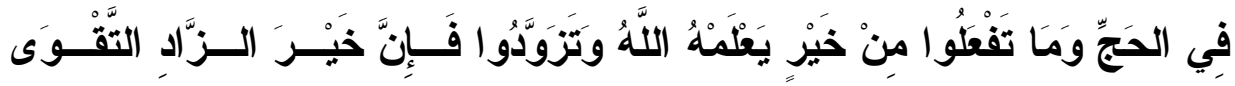

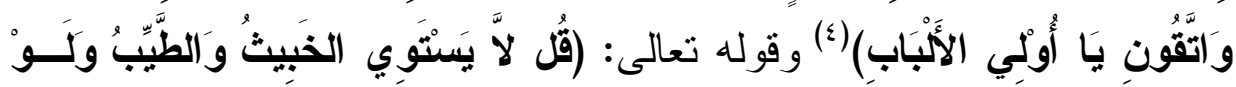

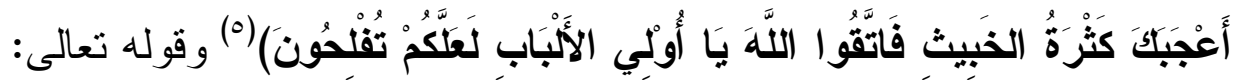

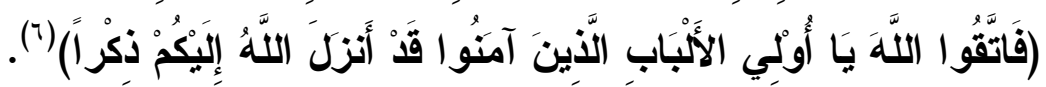

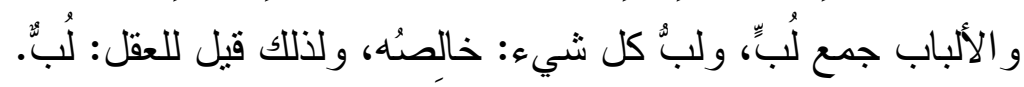

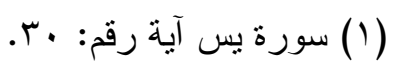

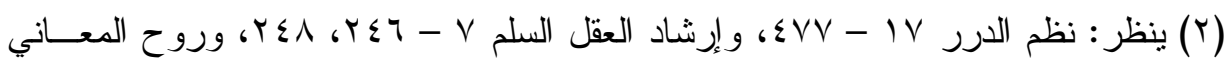

$$
\begin{aligned}
& \text { r ror - r }
\end{aligned}
$$

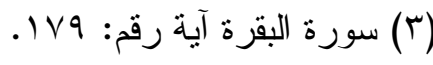

$$
\begin{aligned}
& .19 V: \\
& \text { (0) سورة المائدة آية رقم: . .1. } \\
& \text { (T) سورة الطلاق آية رقم: .1. }
\end{aligned}
$$


وخَصَّ أولي الألباب بالخطاب - و إن كان الأمر يعم الكل - لأنهم الذين قامت

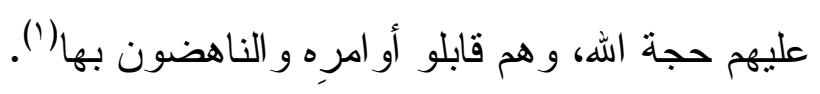

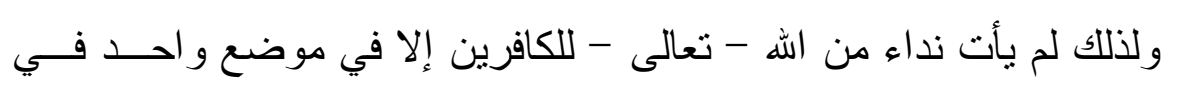

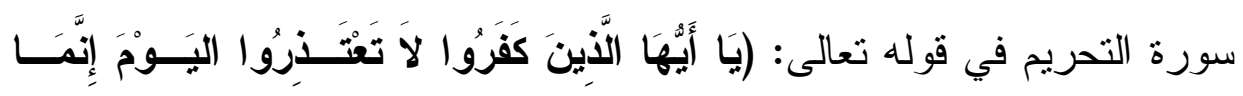

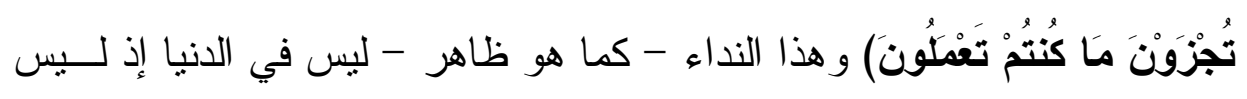
لهم أهلية الخطاب، و إنما هو في الآخرة، وهي ليست دار تكليف - فنداؤهم في

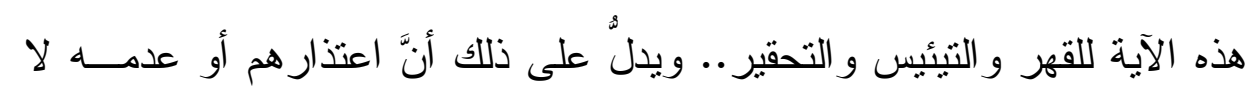
اعتداد به في الحالتين إذ لن يحصل من هذا أو ذاك قبول منهم. و هنالك موضع آخر لكنه ليس من نداء الله - تعالى - لهم و إنما هـــ مــن

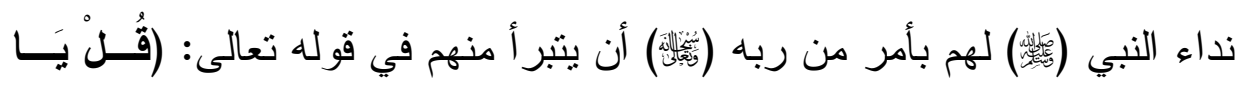

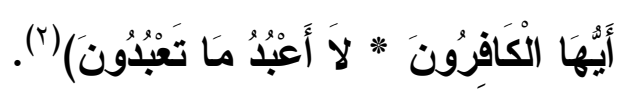

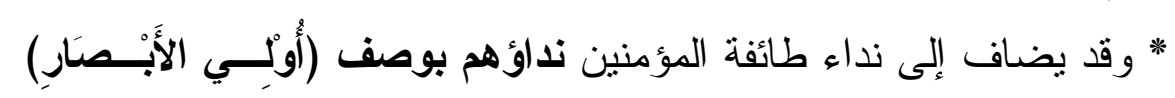

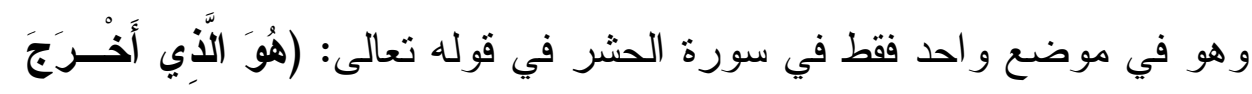

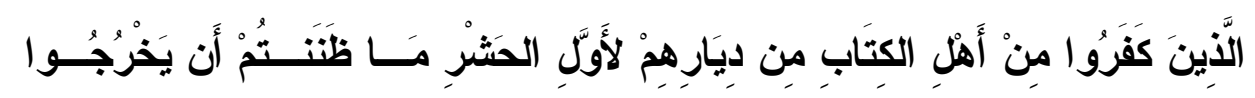

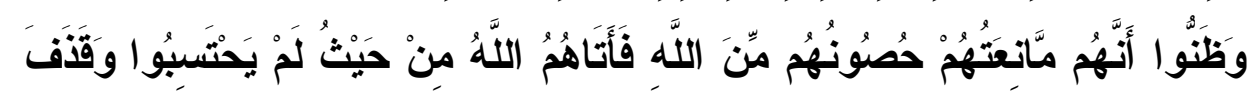

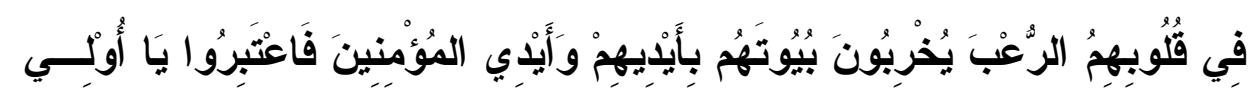

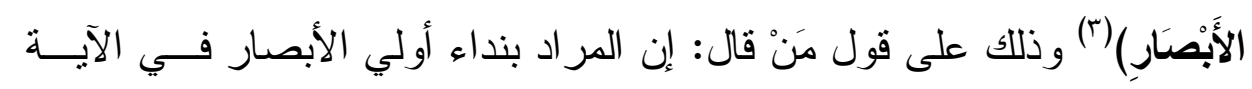

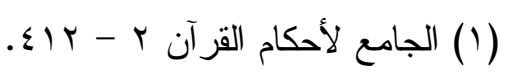

$$
\begin{aligned}
& \text { (Y) سورة الكافرون آية رقم: } 1 \text { (Y }
\end{aligned}
$$

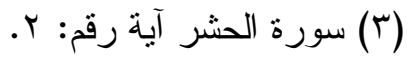


الكريمة هم المؤمنون لأنَّ الاعتبار عظيم النفع، وهو لا يحــصل إلا للكَُّــل (1)

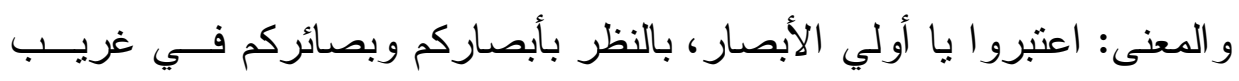

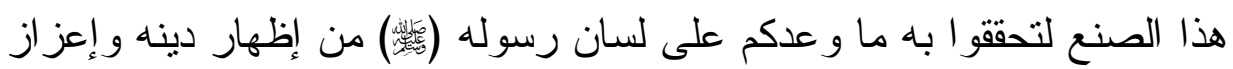
نبيه و لا تعتمدو ا على غير الله كما اعتمد هؤلاء على المنافقين(؟). * ويدخل في ندائهم أيضاً نداء أنفسهم الزكية في قوله تعالى: (يَـــا أَيَُّْهــا

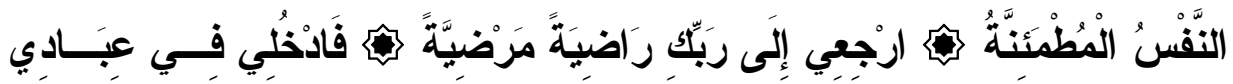

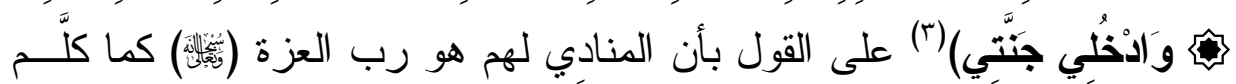

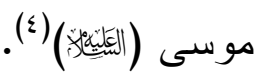
و النداء هنا عام في كلِ نفس مؤمن مخلص طائع (0) ويكون هذا النداء إمسـا

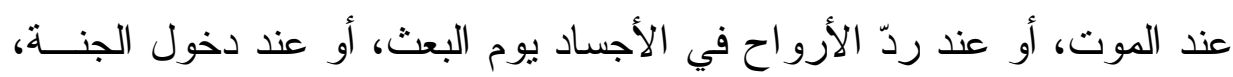

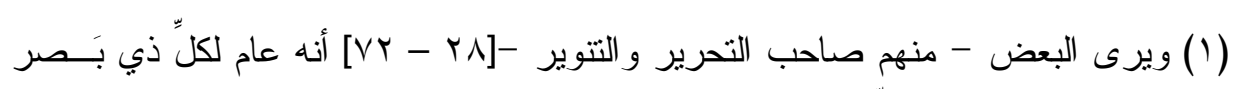

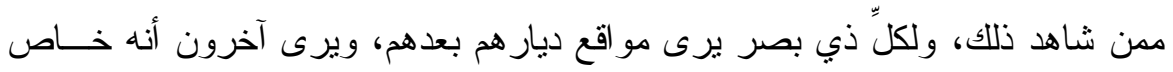

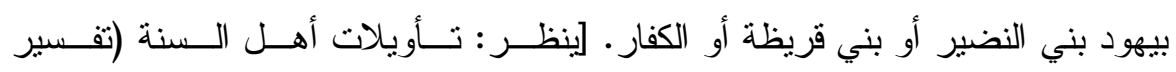

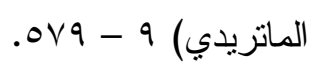

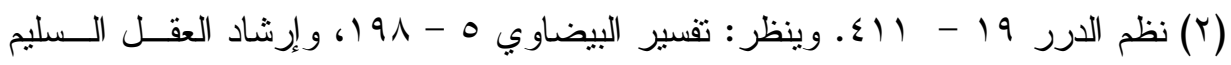

$$
\text { (r) سورة الفجر آية رقم: }
$$

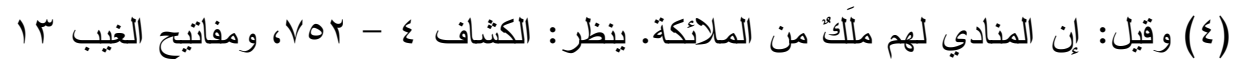

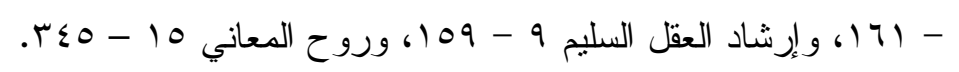

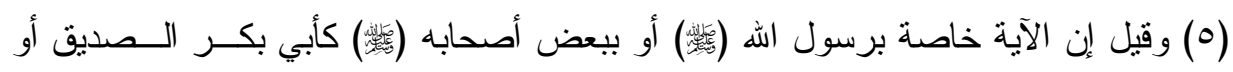

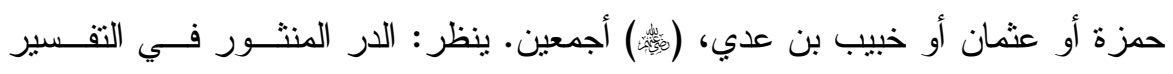

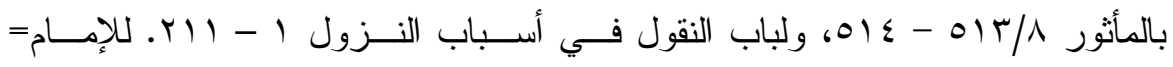


أو هو الآن للمؤمنين؛ على معنى أنه - تعالى - لهَّا ذكر حال الكفار قــال: يــا

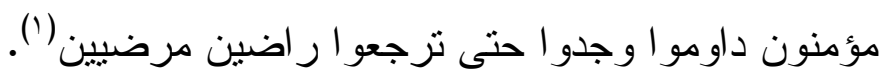

\section{الرابب الرابع}

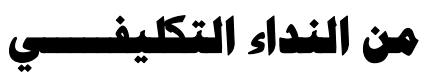

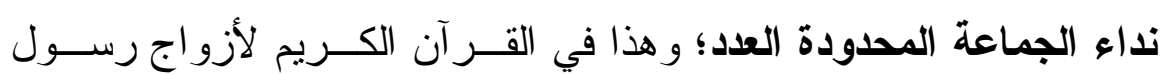

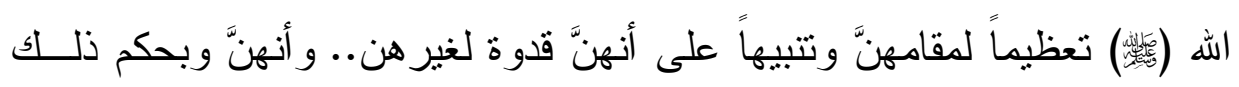

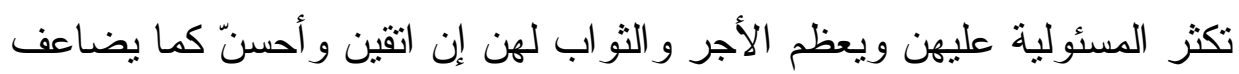

لهن العذاب إن أتين ما أوجب الله العقوبة على فعله (r). وذلك في موضعين اثثين فقط في سورة الأحز اب؛ الموضع الأول في قوله

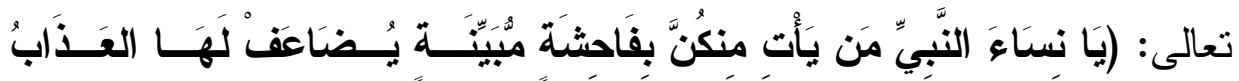

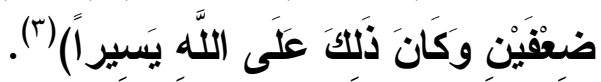

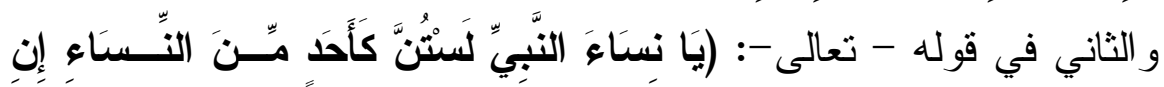

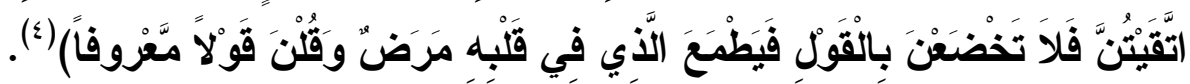

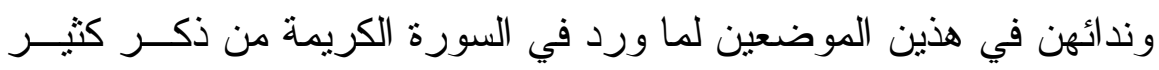

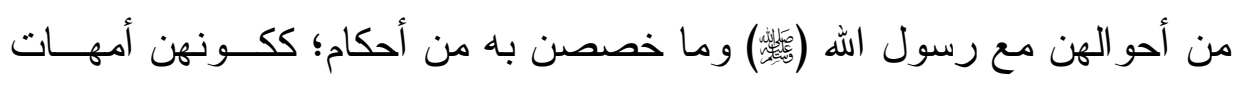

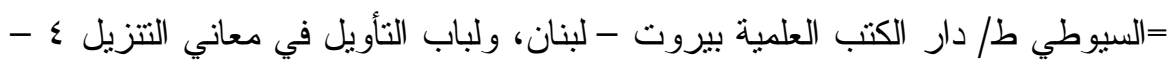

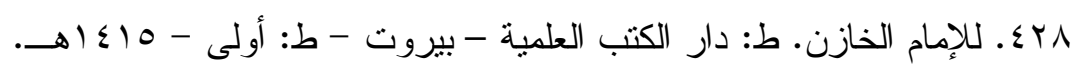

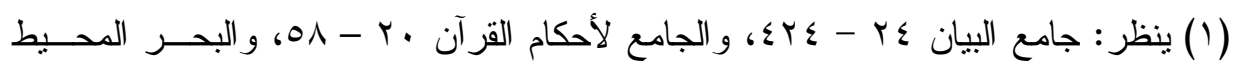

$$
\begin{aligned}
& \text {. } \varepsilon V \nabla-1 \text {. }
\end{aligned}
$$

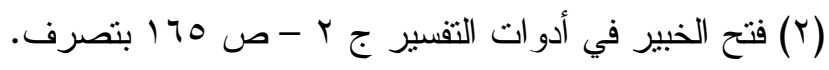

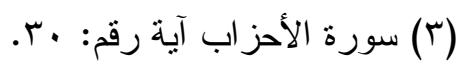

$$
\begin{aligned}
& \text { " }
\end{aligned}
$$




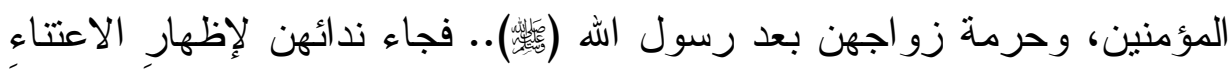
بنُصحهنَّ.

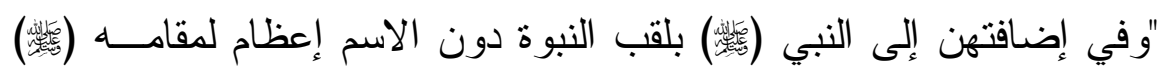

وتتريف لهن، و لأنَّ النبوة هي التي يدور عليها ما يرد عليهن من الأحكام"(').

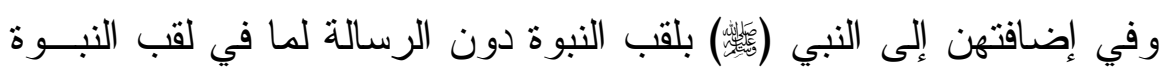

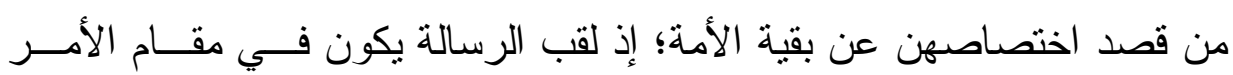

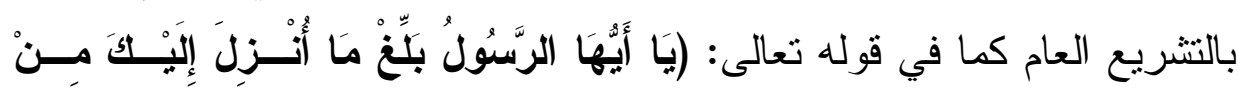

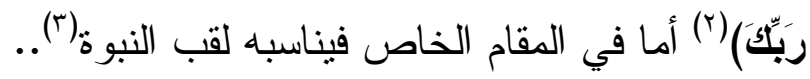

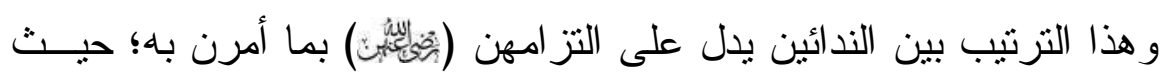

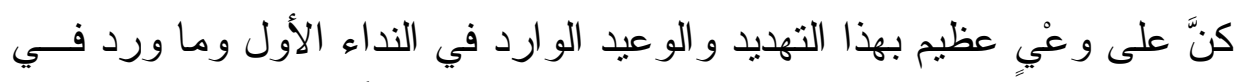

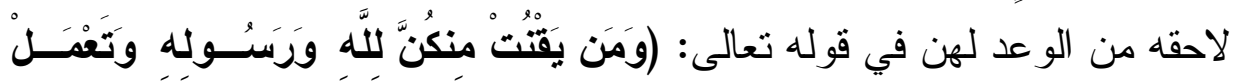

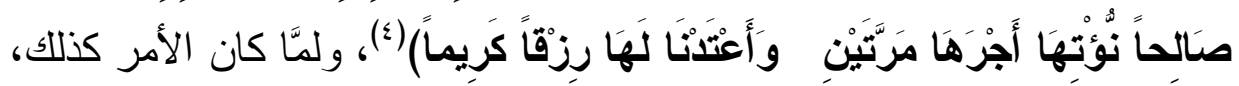

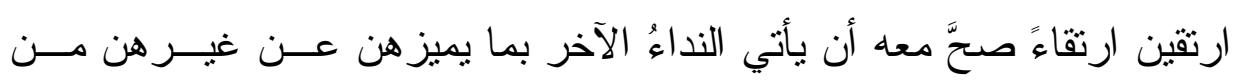

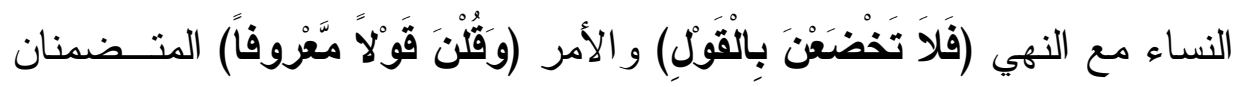
للنصح و التوجيه.

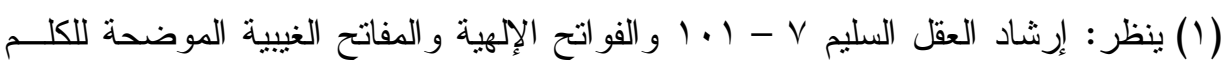

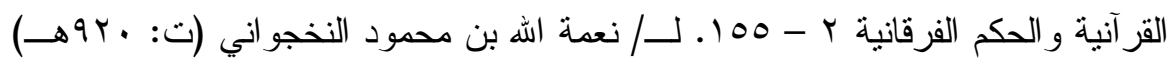

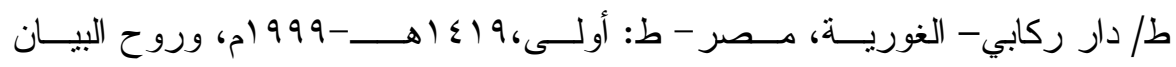
. $177-V$ (Y) سورة المائدة آية رقم: VV)

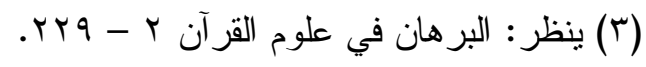

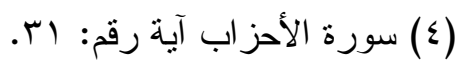




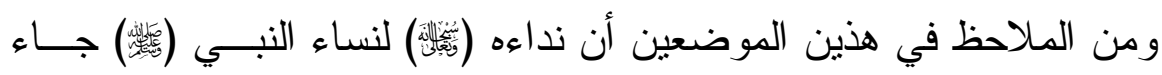

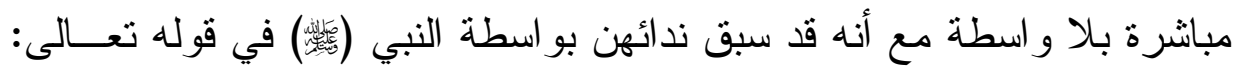

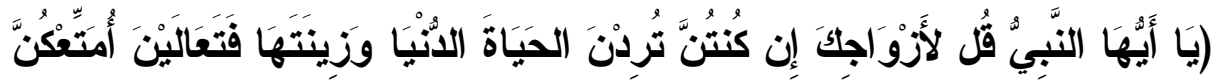

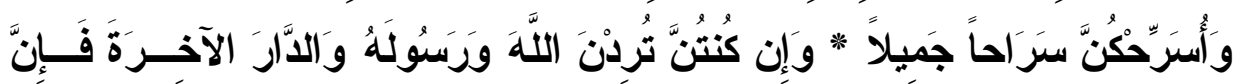

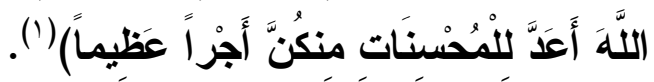
فما الفرق بين ندائهن بواسطة وبغير واسطة في هذه المو اضع؟ كذلك مــــا الفرق بين نداء الله تعالى لهن بلفظ "نساء النبي "دون" أزو اج النبي "؟ يجيب على ذلك أ.د محمد محمد أبو موسى، فيقول: "يتجه الخطاب في قوله

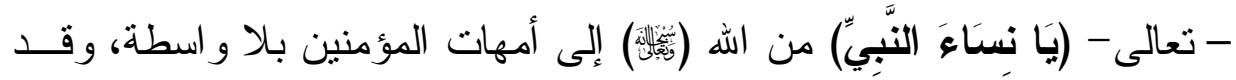

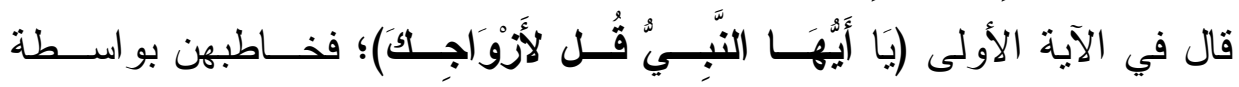

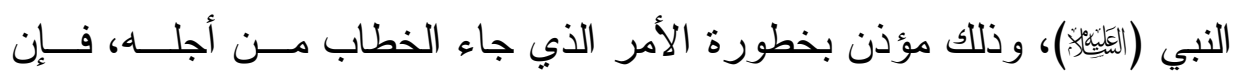
موضوع هذا الخطاب يعالج قضية من أعـضـل القــضايا التــي تعـاني منهـــا المجتمعات الإنسانية، وهي قضية الأخلاق وسلوك النساء، ولذلك آثز هنا لفـــ

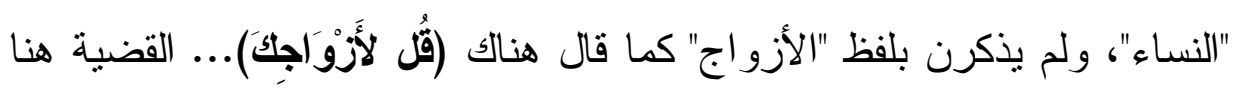
قضية نساء الأرض... و الفاحشة التي يضاعف العذاب لهن مــن أجلهــا مـنـ

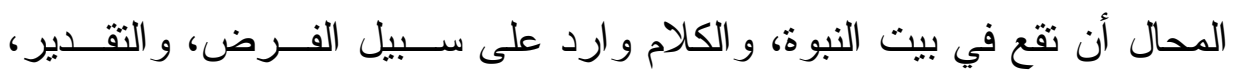
مبالغة في التنفير من هذه الفاحشة، ومبالغة في بيان خطر ها، وهو كلام يلــوِح بسوط العذاب، وبالغ النقمة، و الغضب، على أرباب الخطيئة في الأرضه"هـ (؟).

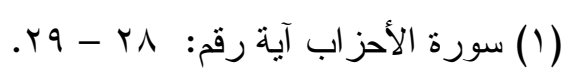

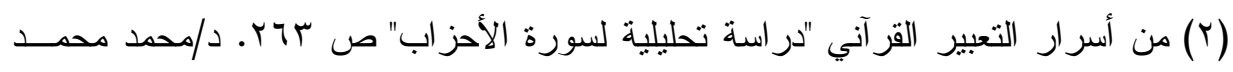

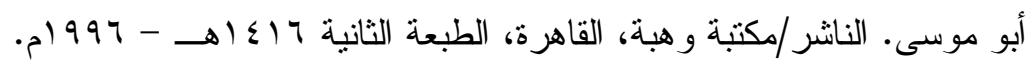




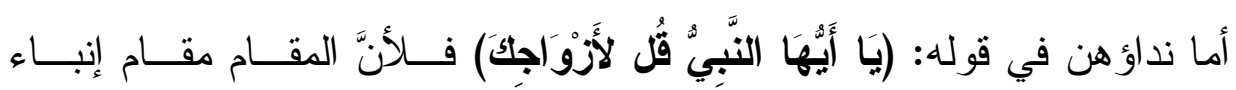

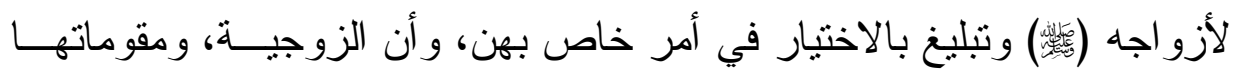

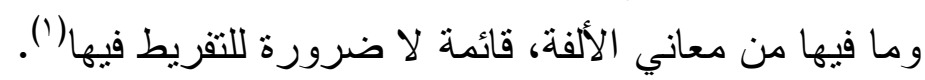

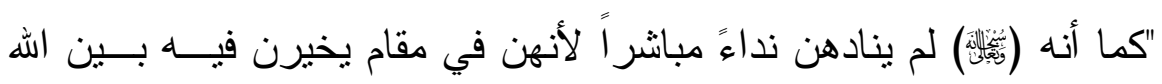

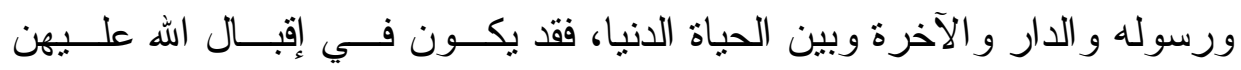
بالخطاب ما يحبب إليهن اختيار الله ورسوله، ولهذا قدم في الاختيار قولــهـ: (إن

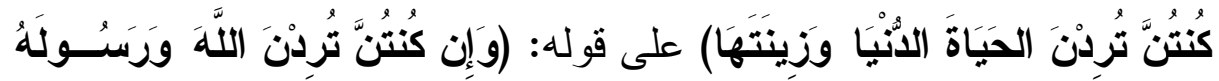
وَالاَّارَ الآخرَةً).

وتكر ار ندائهن في هذه الآيات يشير إلى أهمية الغرض الذي سيق الحـديث من أجله، مع ما في حرف النداء "يا "من امتداد الصوت المؤذن بالبلاغ" (؟).

\section{الإطاب الفامس}

\section{هن النداء التكسيف: نداء الأفراد أو الأشخاص(r)"}

و هو إمَّا نداء بالاسم أو بالصفة أو بحالة صار إليها لمناسبة خاصة.

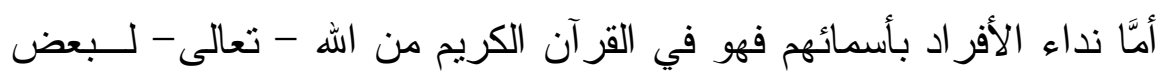

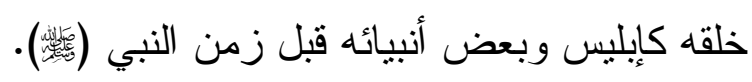

(1) ينظر استخدام القر آن لكلمة الزوج و المر أة في كتاب: خصائص التعبير القر آني وســماته

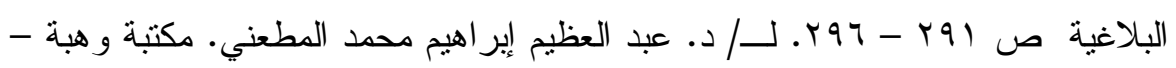

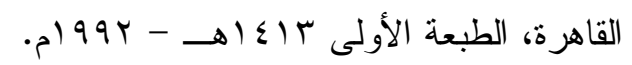
(Y)

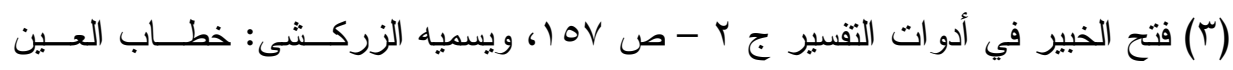

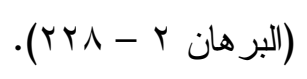


أما نداؤه (َّيَّلَ) لإبليس عليه اللعنة فلم يرد إلا في قصة سجود الملائكة لآدم

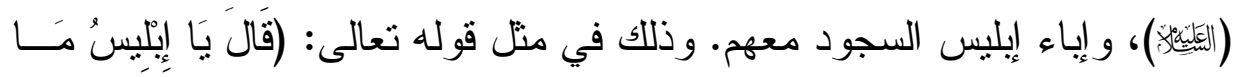

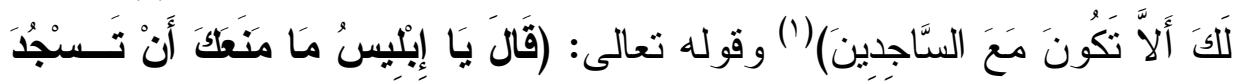

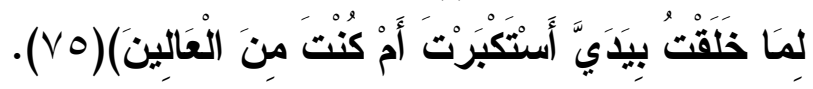

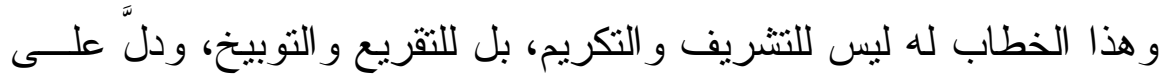
ذلك: نداؤه باسم "إبليس" وهو من الإبلاس ومعناه اليأس من كل خير، و السكون

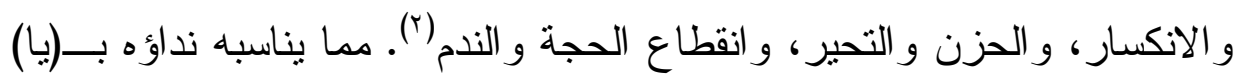

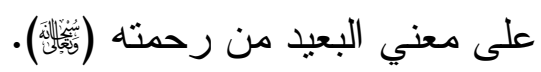

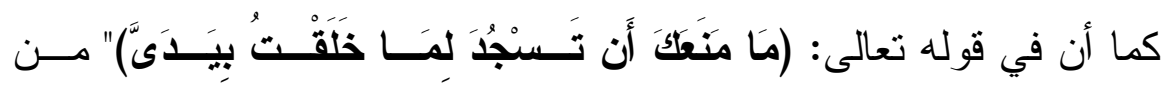

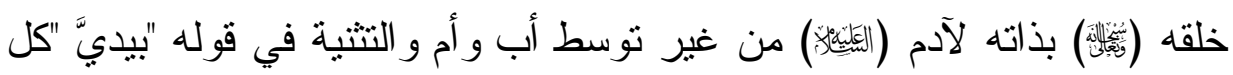

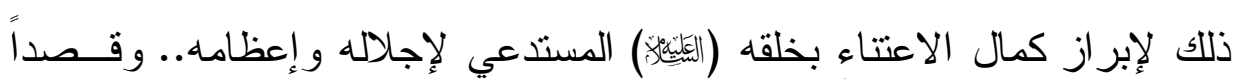
إلى تأكيد الإنكار وتنثديد التوبيخ.

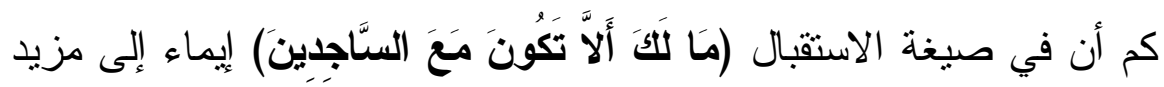

$$
\text { قبح حاله.. إلى غير ذلك"("). }
$$

وظاهر هذا النداء يقتضي أن الله - تعالى - تكلم مع إيليس بغير و اســة، إنه

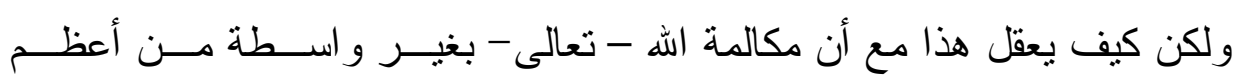

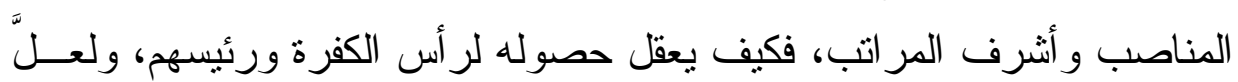
الجو اب - كما ذكر الإمام الرازي - أن مكالمة الله - تعالى - إنما تكون منصباً

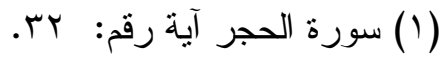

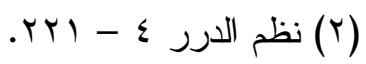

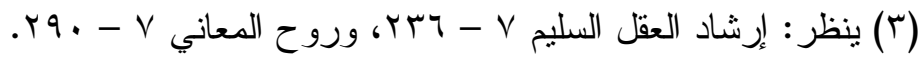


عالياً إذا كان على سبيل الإكر ام و الإعظام، فأمَّا إذا كان علــى ســبيل الإهانـــة و الإذلال فلا" ('). (النان

كما لا يخفي ما في ندائه - تعالى - لإبليس -عليه اللعنة - بدون و اســـة

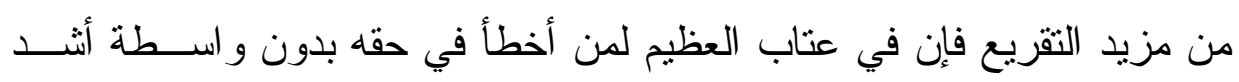
نكاية، و إثتعار بمزيد الندم، و الحسرة.

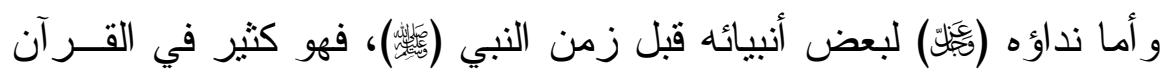

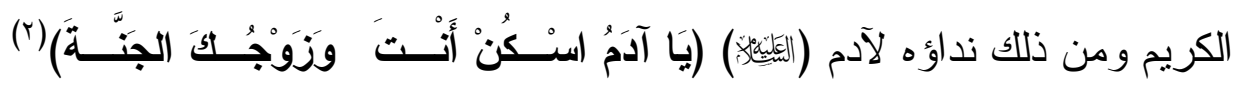

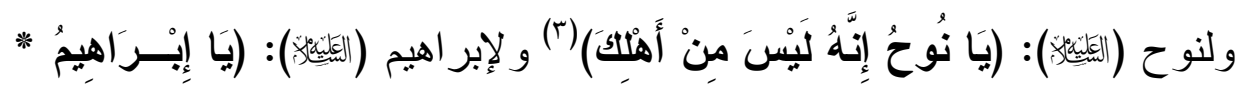

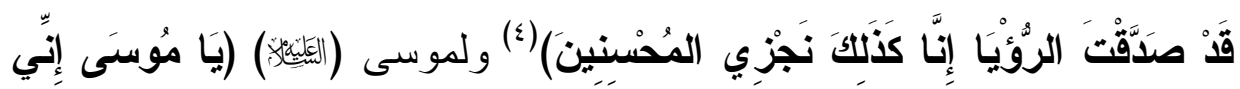

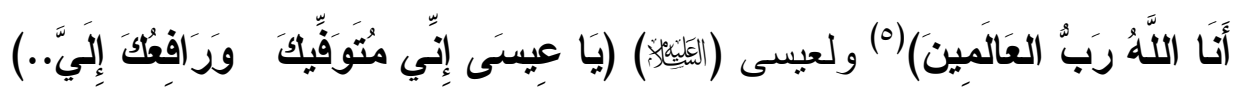
الآية(؟).. إلى غير ذلك.

ويلاحظ في هذه المو اضع أنه تعالى نادى هؤلاء الأنبياء بأسمائهم فما السرٌّ

في ذلك؟

يجيب على ذلك الثيخ / محمود شلتوت بقوله: "ناداهم بأسمائهم استتهاضـــاً

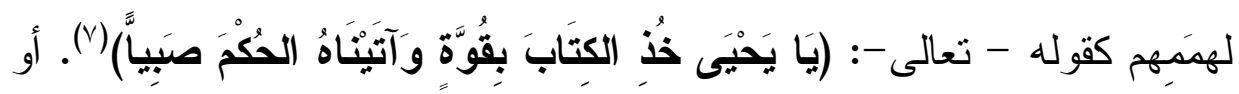

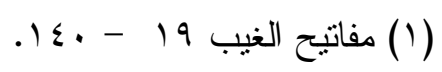

$$
\begin{aligned}
& \text { (Y) سورة البقرة آية رقم: هr. }
\end{aligned}
$$

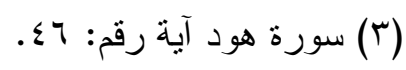

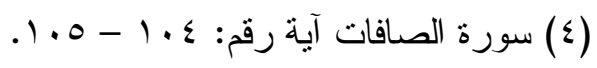

$$
\begin{aligned}
& \text { (0) سورة القصص آية رقم: . بـ. } \\
& \text { (ך) سورة آل عمران آية رقم: } 00 . \\
& \text { سورة مريم آية رقم : سأ. }
\end{aligned}
$$




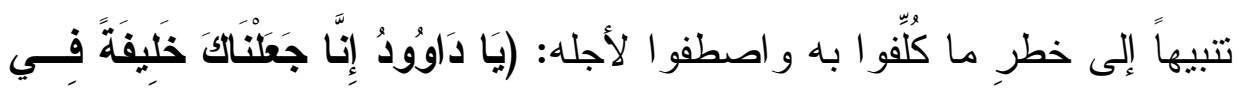

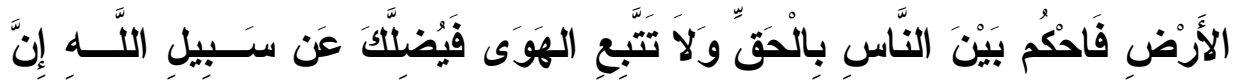

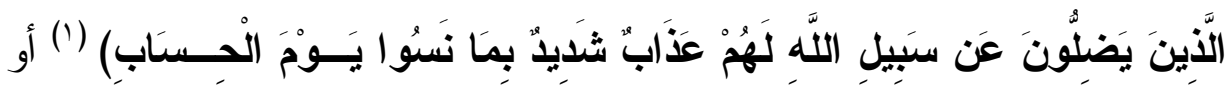

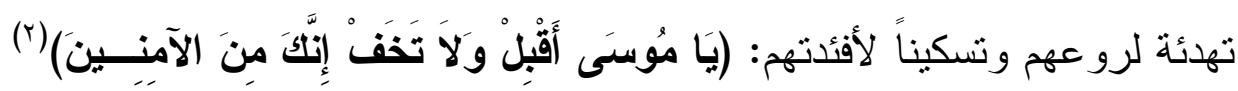
(r)

قلت: وقد تظهر المفارقة أكثر في هذا النوع من الندّاء - أي نداء الاسم -

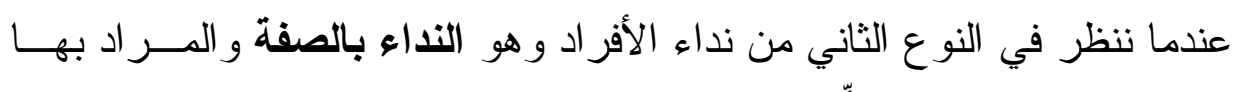
هنا "صفة النبوة" وهذا النِّداء في كتاب الله - تعالى - قد خصَّ به خاتم الأنبيــاء

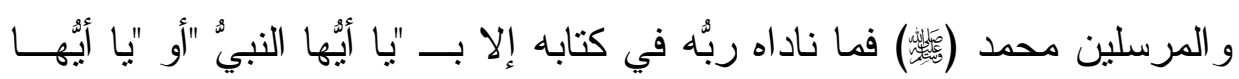
الرَسَسُول".

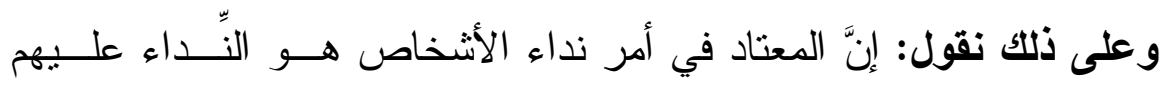
بأسمائهم مع ما في ذلك من الإقبال عليهم، و التلطف بهم تهيئة لاستقبال ما يــرد

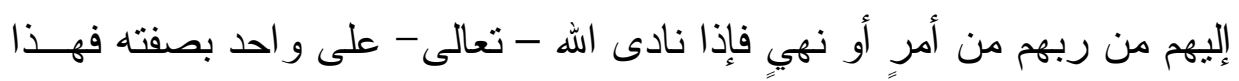
ما يحتاج إلى زيادة نظر وتأمل..

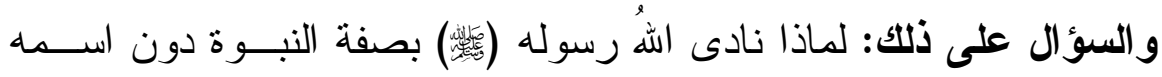

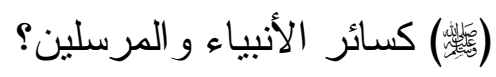

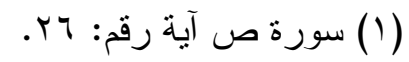

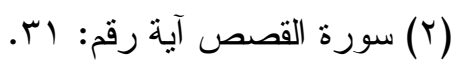

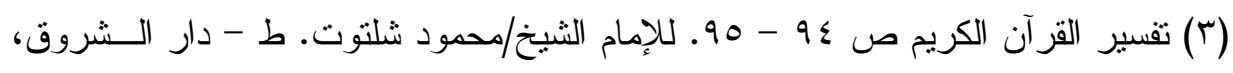

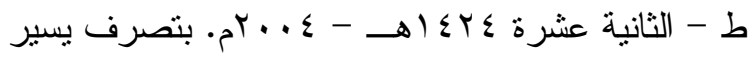




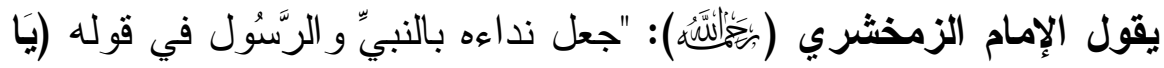

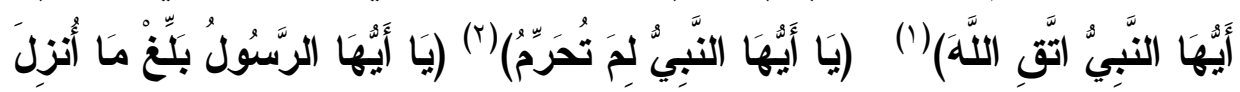

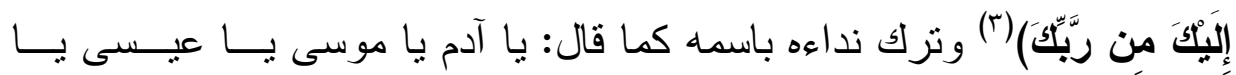

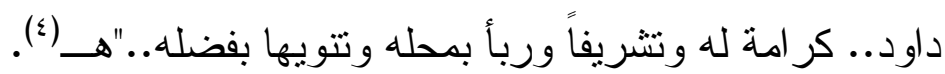

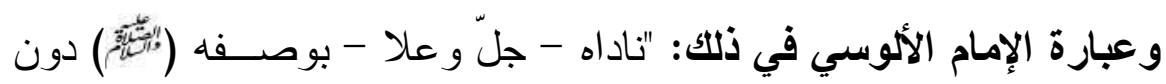

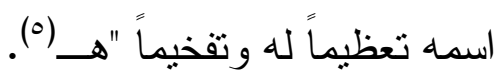

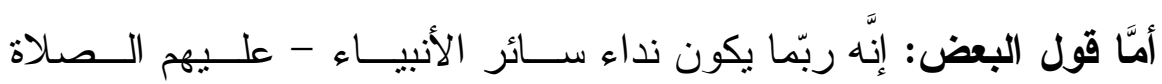

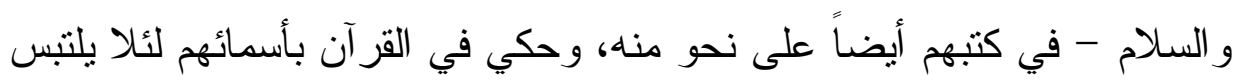

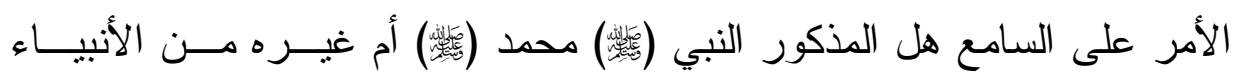

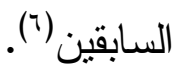

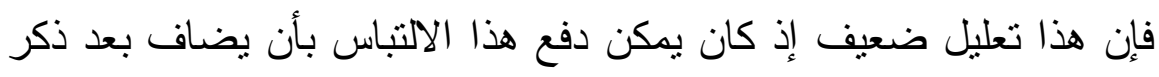

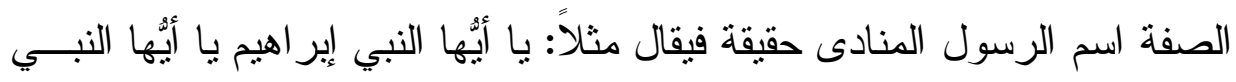

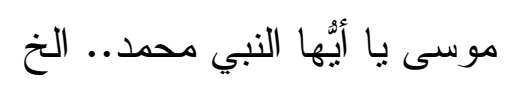

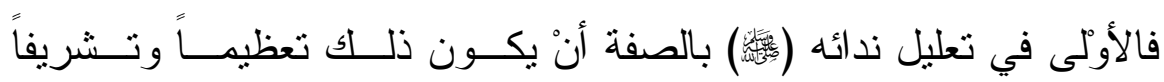

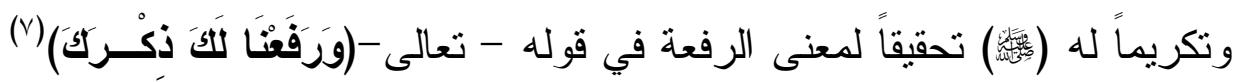

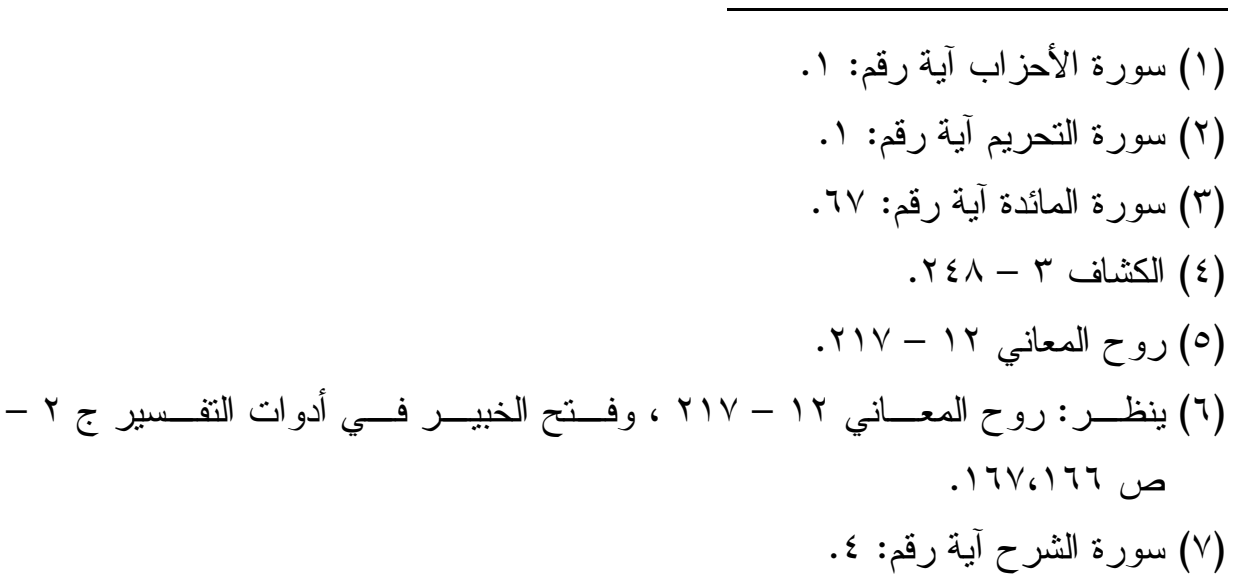




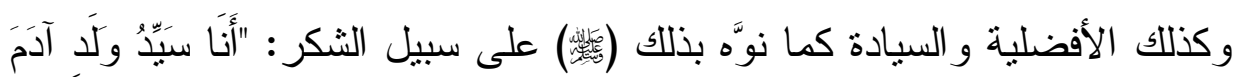

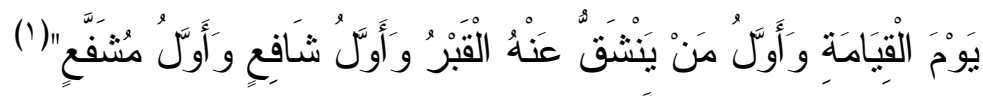

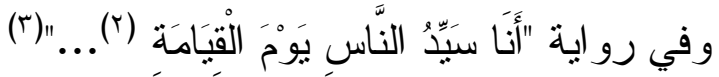

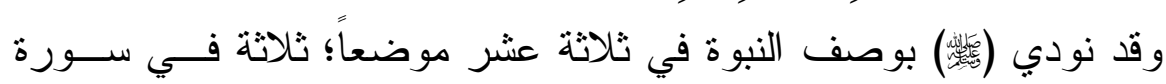

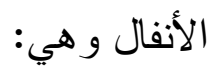

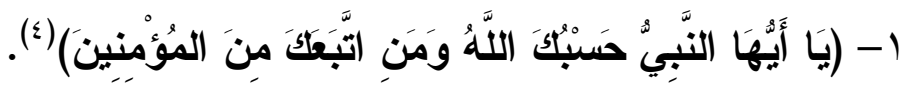

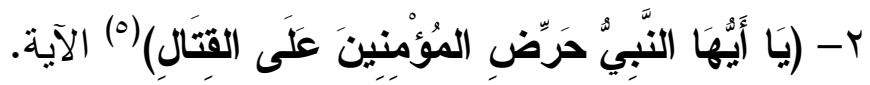

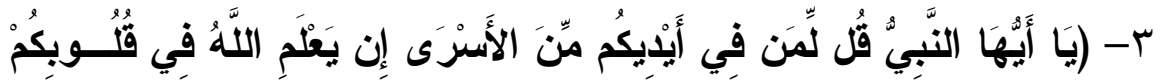

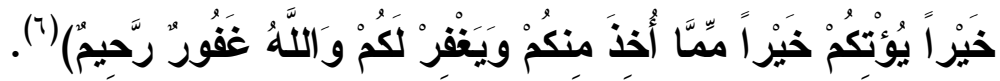

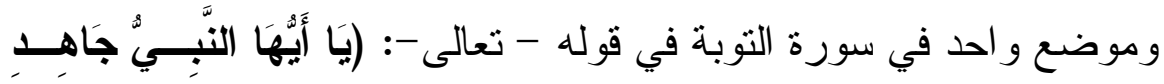

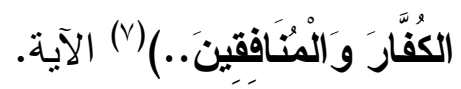

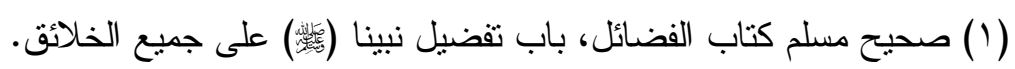

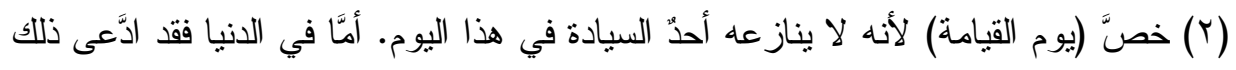

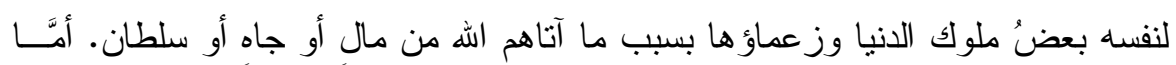

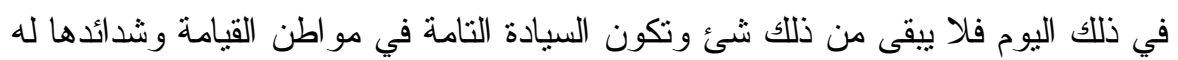

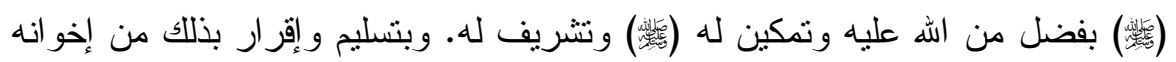

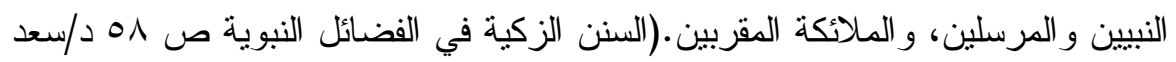

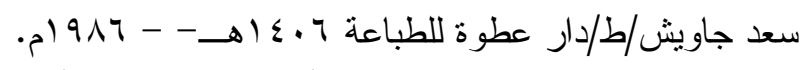

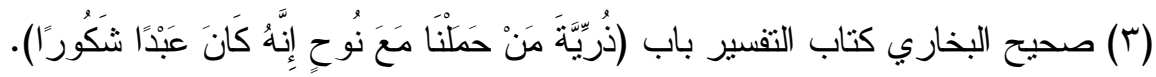

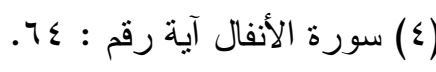

.70 :

. v. :

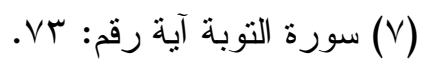




$$
\text { ومو اضع خمسة في سورة الأحز اب: }
$$

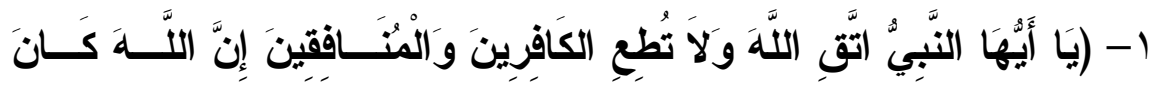

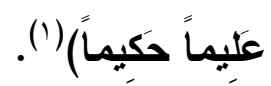

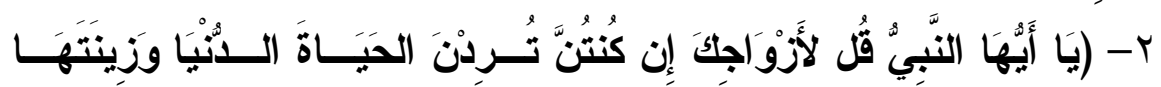

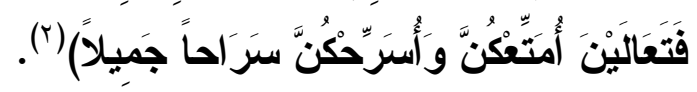

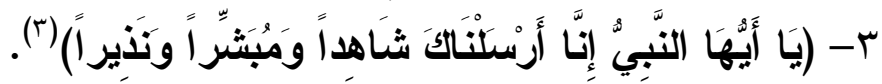

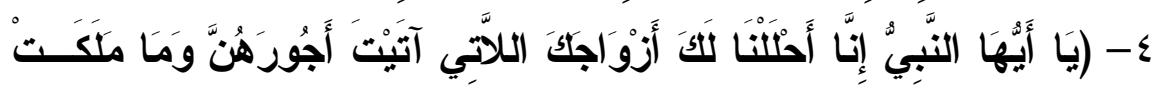

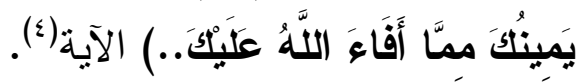

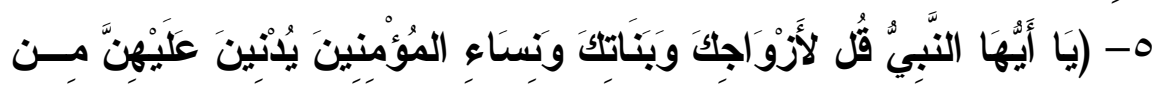

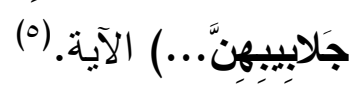

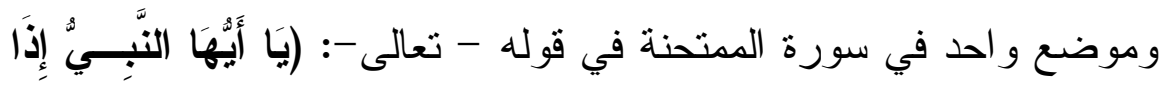

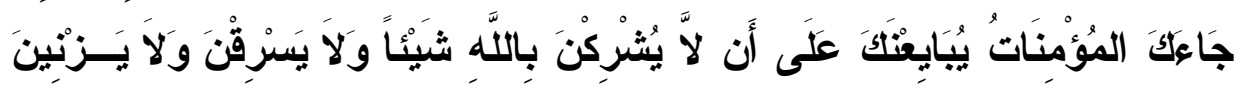

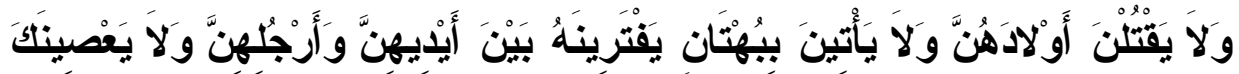

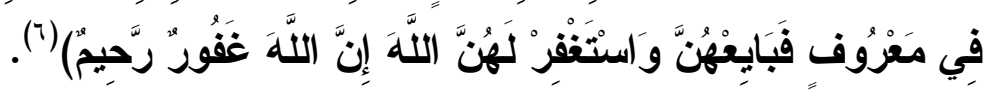

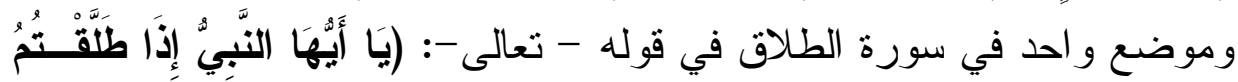

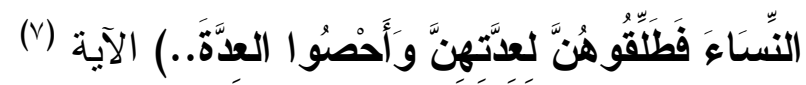

$$
\begin{aligned}
& \text { (1) سورة الأحز اب آية رقم: } 1 . \\
& \text {. Yᄉ : " " " " (Y) } \\
& \text {. so: } \\
& \text {.0.: } \\
& \text { (0) سورة الأحز اب آية رقم: } 09 .
\end{aligned}
$$

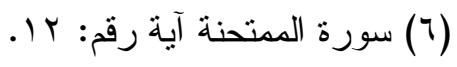

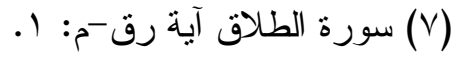




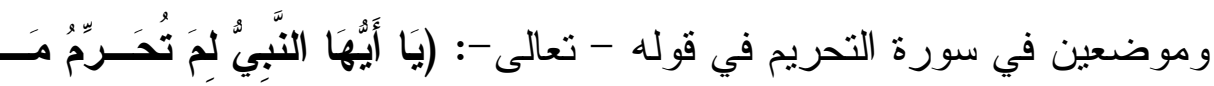

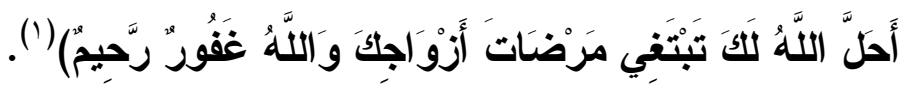

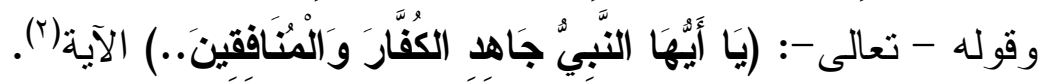

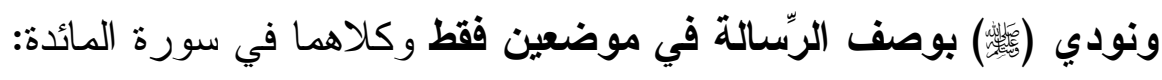

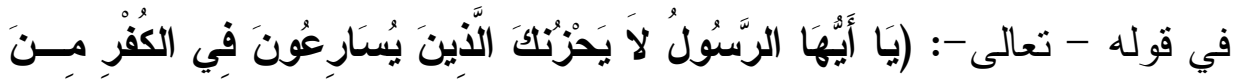

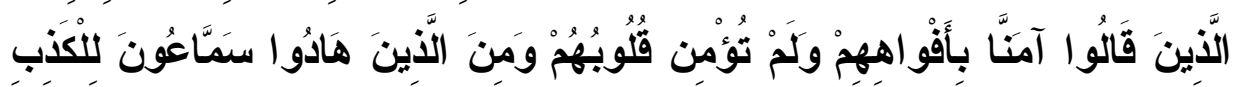

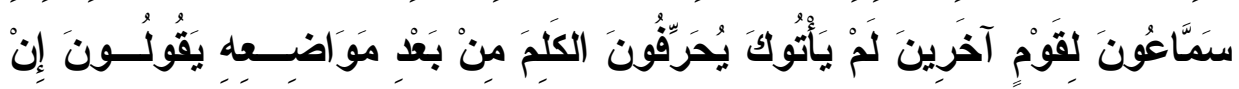

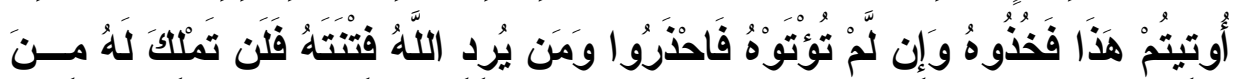

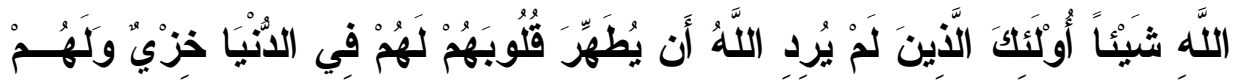

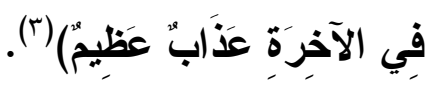

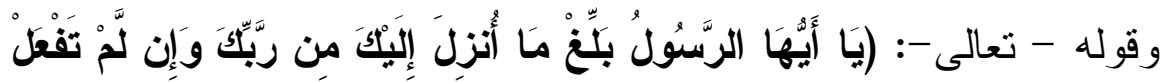

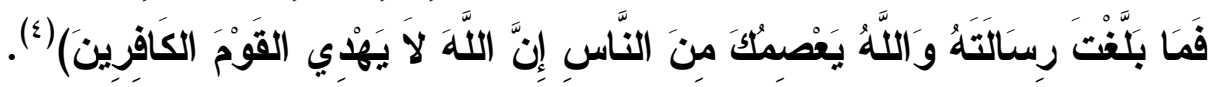

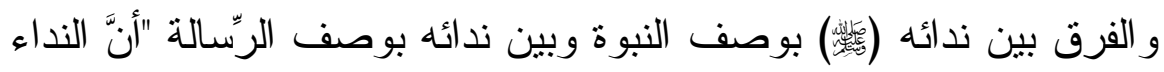

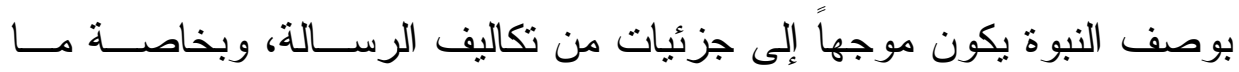

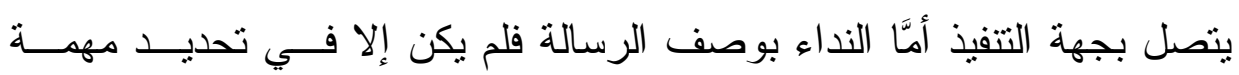

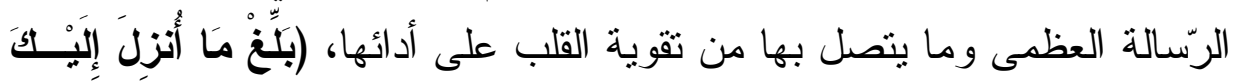

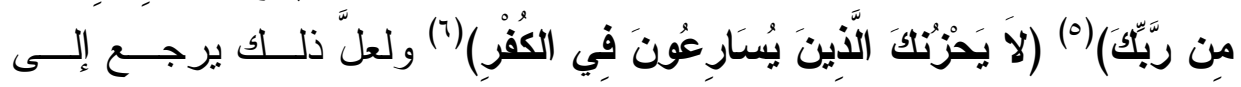

$$
\begin{aligned}
& \text { (1) سورة التحريم آية رقم } 1 . \\
& \text { (Y)سورة التحريم آية رقم: } 9 .
\end{aligned}
$$

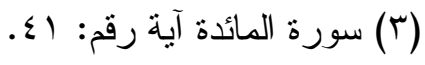

$$
\begin{aligned}
& \text {.TV: } \\
& \text { (0) سورة المائدة آية رقم: VVIV. } \\
& \text {. VI : }
\end{aligned}
$$


طبيعة لفظي (نبي) و (رسول) في اللغة العربية و اقتضاء أولهما معنى العرفـان

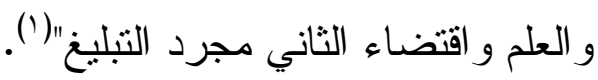
قلت: وعلى أساس هذا الاختلاف اللغوي بين النبيّ و الرسول نرى القــر آن آن

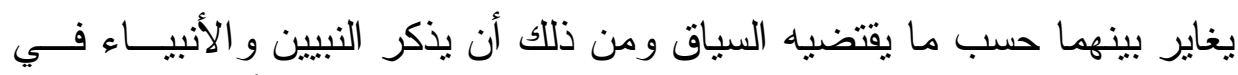

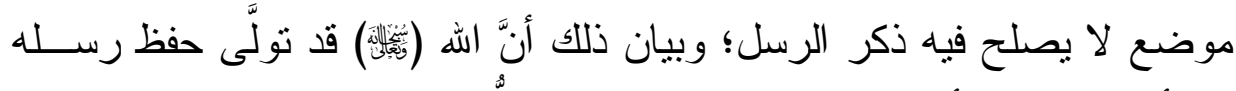

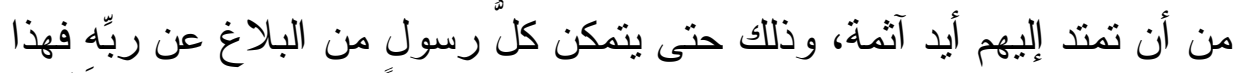

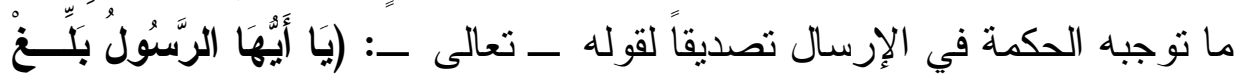

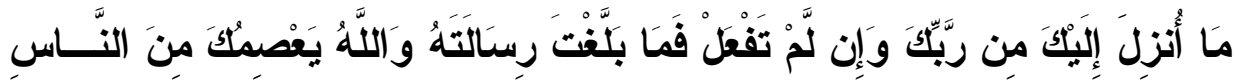

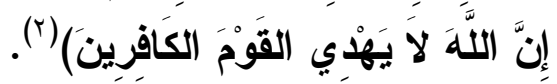

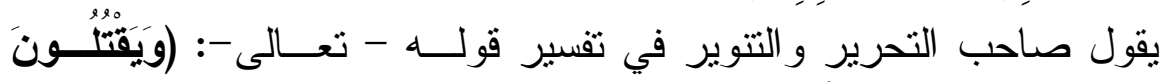

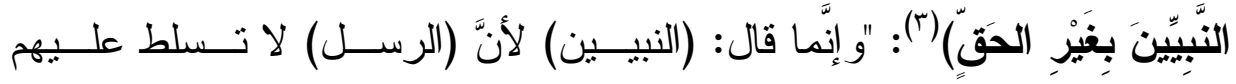

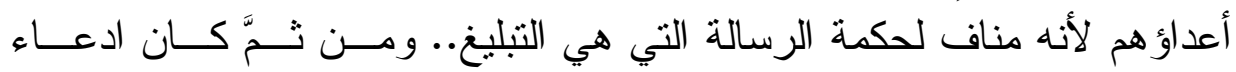

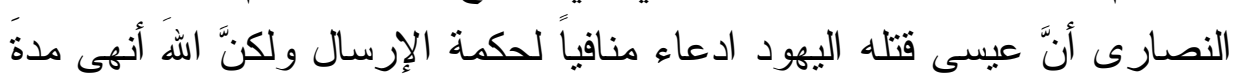
رسالته بحصول المقصد ممّا أرسل إليه"هــ(ء).

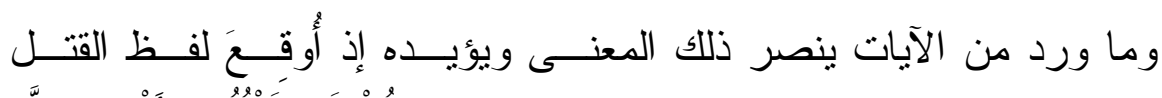

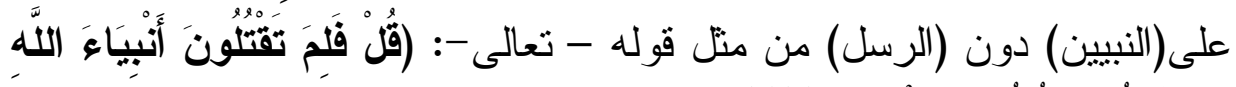

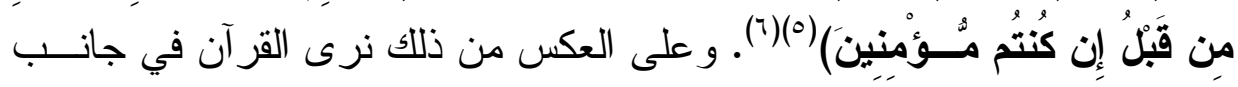

$$
\begin{aligned}
& \text { (1) تفسير القرآن الكريم ص } 97 . \\
& \text { (Y) سورة المائدة آية رقــ (T) }
\end{aligned}
$$

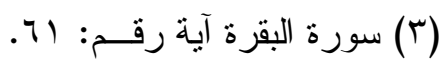

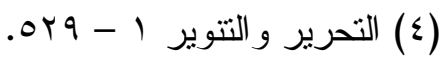

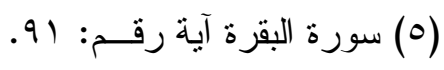

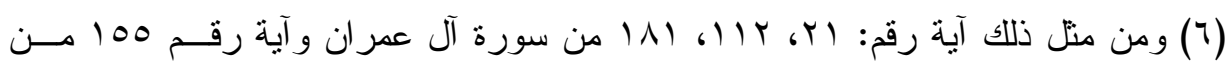
سورة النساء 


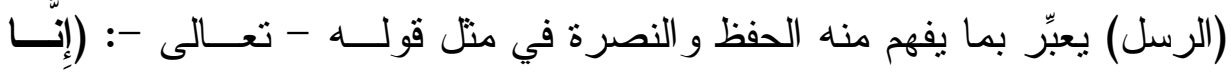

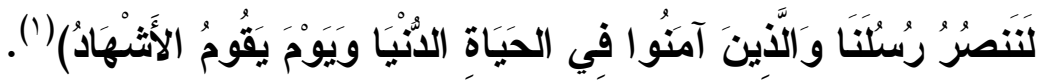

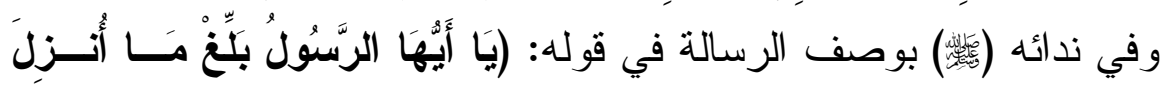

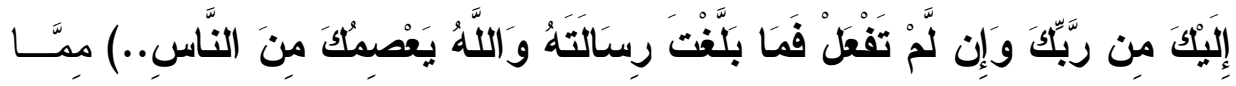

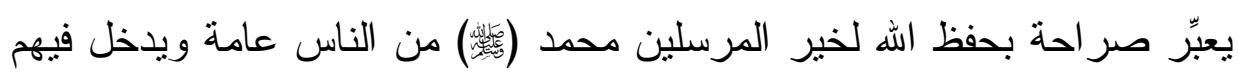
اليهود دخو لاً أولياً - كما ينبئ عنه سياق الآية - حيث جاءت في سياق الحديث

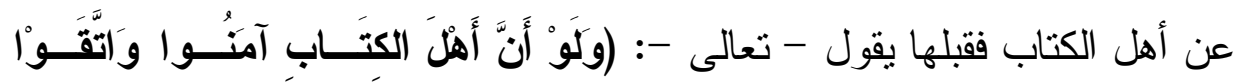

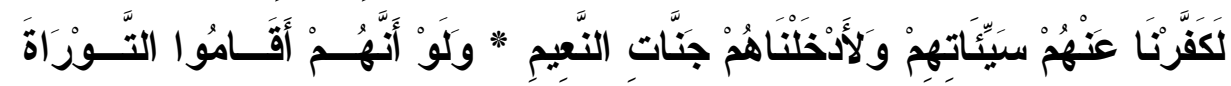

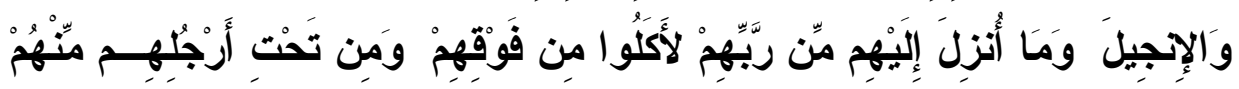

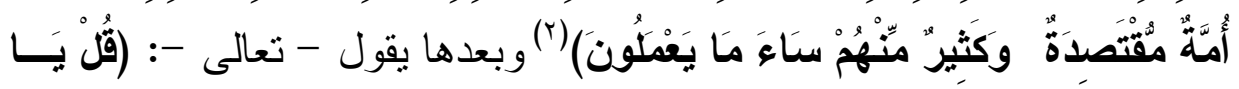

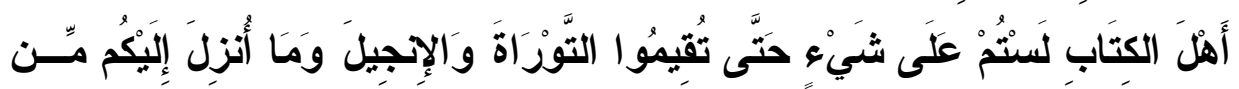

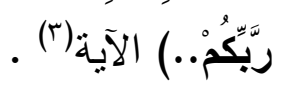

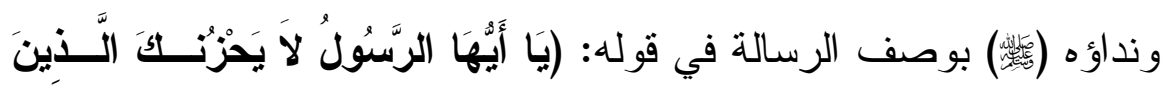

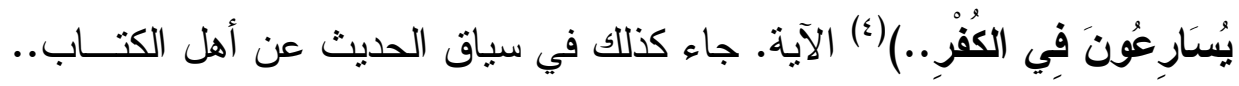

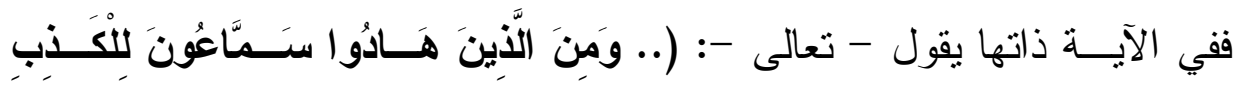

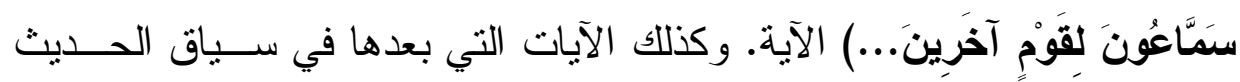
عن أهل الكتاب. فجاء النداء بوصف الرسالة هنا وهناك ليطمــئن رســول الهـ

$$
\begin{aligned}
& \text { (1) سورة غافر آية رقـم: }
\end{aligned}
$$

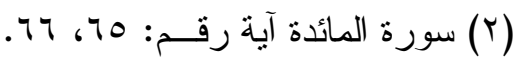

$$
\begin{aligned}
& .71 \text { : } \\
& \text { (乏) : }
\end{aligned}
$$




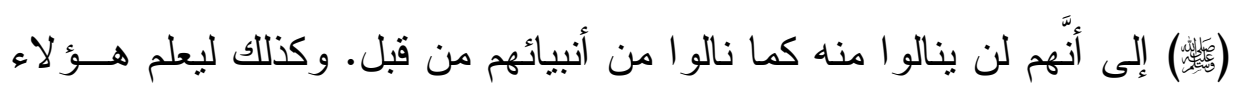
أن ليس لهم إلى رسول الله (ئس

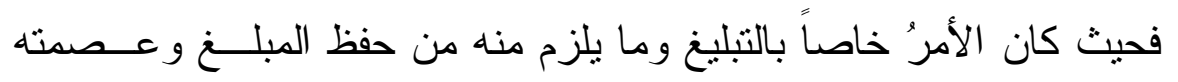
أوثر النداء بوصف الرسالة. و إن كان الأمر خاصاً بجزئيات من تكاليف الرسالة وما يتصل بذلك من تتفيذ أوثز النداء بوصف النبوة. و الله أعلم.

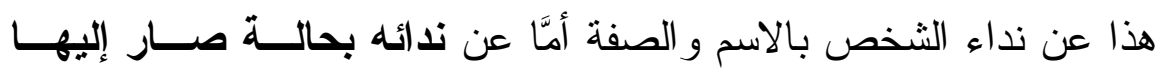

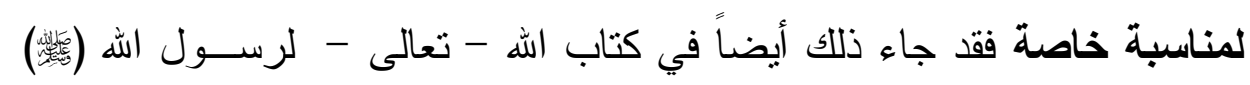

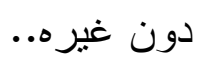

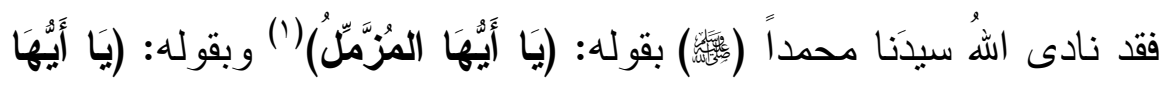

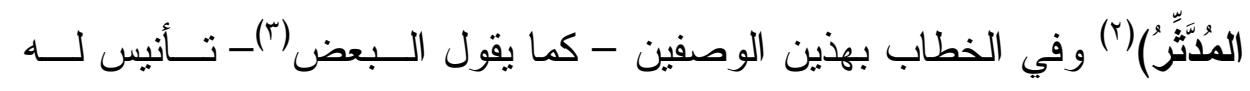
وملاطفة على عادة العرب في اثتقاق اسم للمخاطب من صفته التي هو عليها،

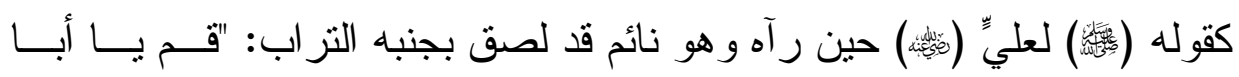

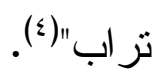

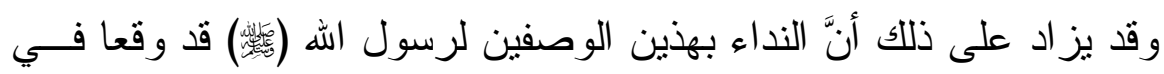

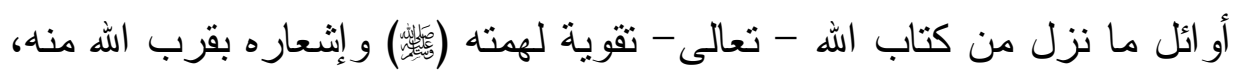

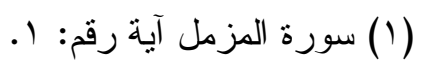

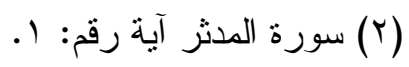

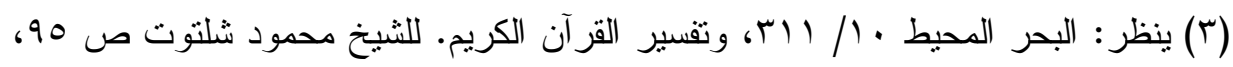

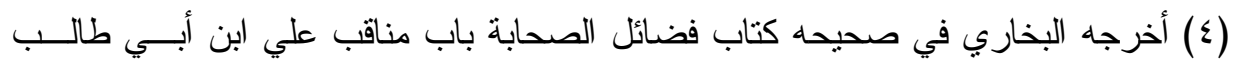

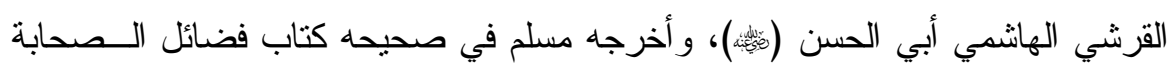
( 
و عنايته به على كافة أحو اله وشئونه (筷) مما له الأثر البالغ في تحمل مـشاق الدعوة، وطر ح أبي دافع بؤدي إلى التكاسل عنها..

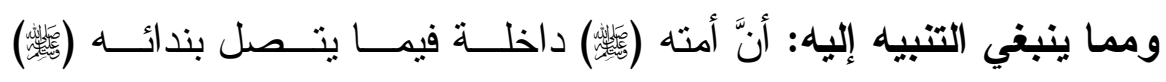

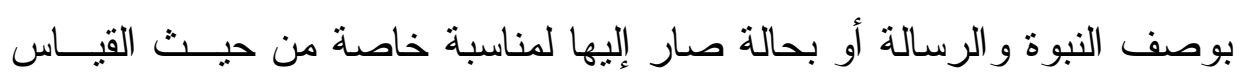
و غيره لا من حيث وضع اللسان أو من حيث اللفظ إذ لفظ النبي ليس مـستعملا

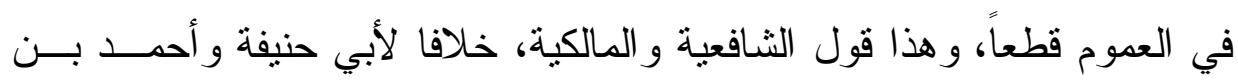

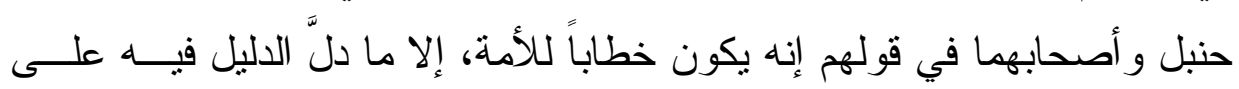

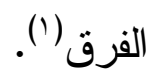

وبعد،،

فهذا - لا شك - قليل من كثير عن مغزى ودلالات النداءات الإلهية فـي

القر آن الكريم، وما اتصل به من نداء المخلوقات على سبيل المثال لا الحــصر ،

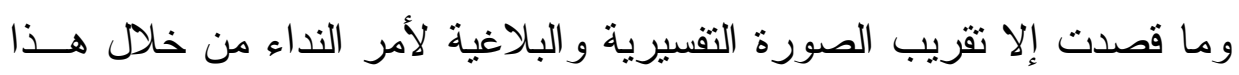
الموضوع.

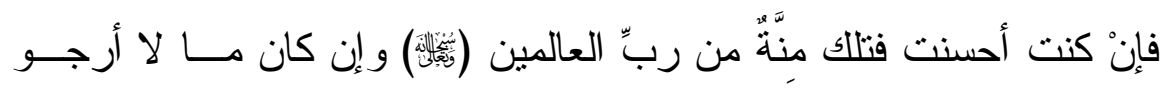
فحسبي من ذلك أنِّي اجتهدت، و على الله قصد السبيل، ومنه التوفيق و العون.. وصلح الله علحسبدنا محمد وعلم اللهوصحبه وسلم

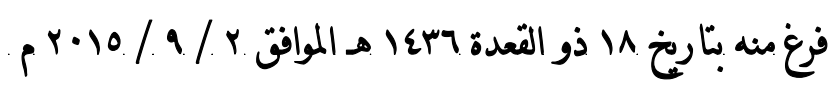

(1) ينظر : الإحكام في أصول الأحكام r - rV9. لــ/ علي بـن محمــد الآمـدي. طا دار

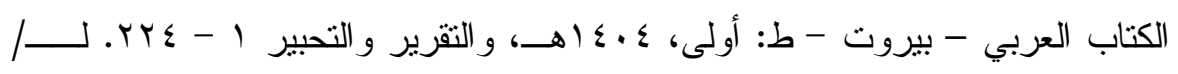

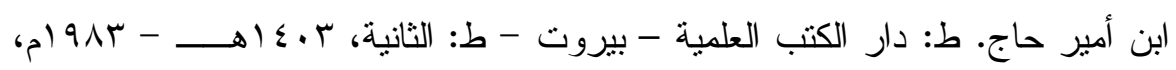

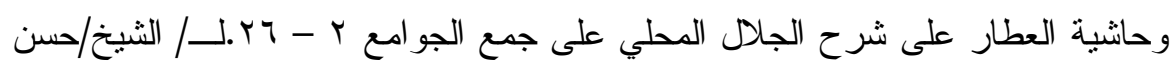

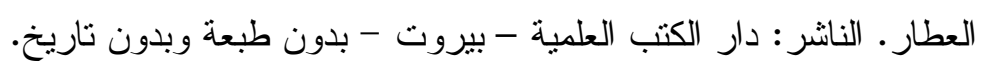




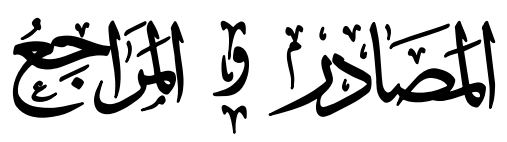

* إجابة السائل شرح بغية الآمل. ــ/ محمد بن إسماعيل الـصنعاني. ط/

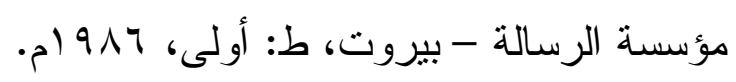

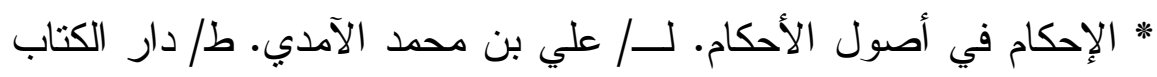

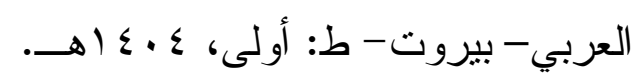

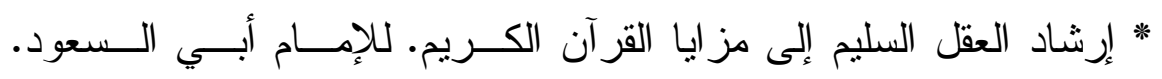

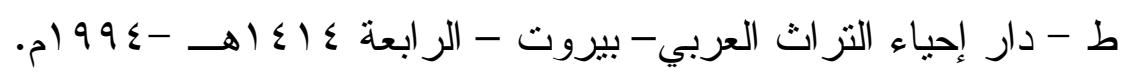

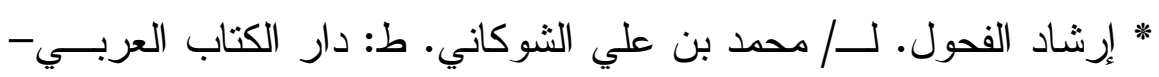

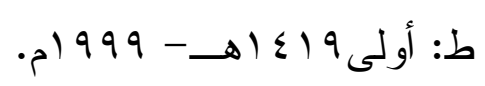

* الأساليب الإنثائية في النحو العربي / عبد السلام هـارون - ط - دار

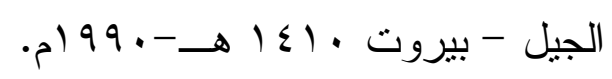

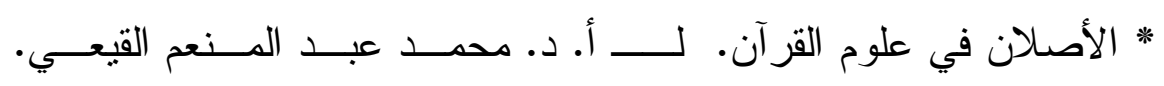

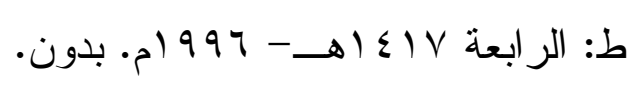

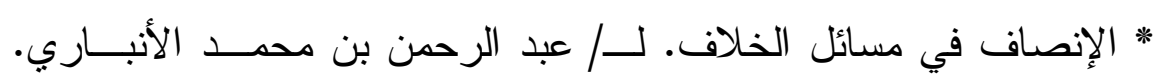

$$
\text { ط - دار الفكر. }
$$

* أنوار النتزيل و أسرار التأويل "تفسير الإمام البيــضاوي. طا دار إحيــاء

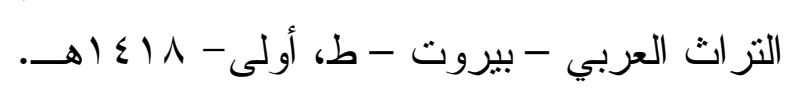

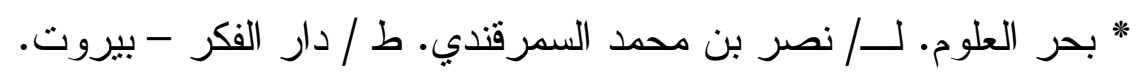

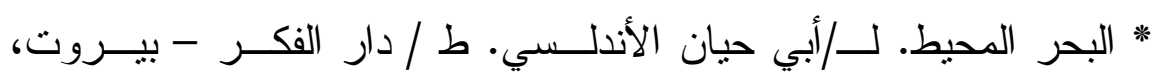

$$
\text { . } \rightarrow \text {. } 1 \leqslant r
$$

* البرهان في علوم القرآن للإمام الزركثي. مكتبة دار التزاث - القاهرة. 


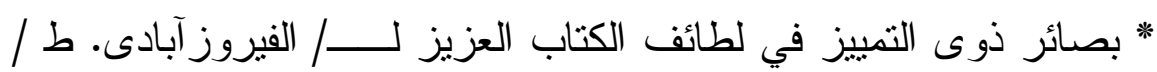
المجلس الأعلى للشئون الإسـامية - لجنة إحياء التــر اث الإســامي، القــاهرة $.01997-\rightarrow 1 \leqslant 17$ * البلاغة العربية لــ/ عبد الرحمن حَبَّكَة. ط- دار القلم. بيـروت - ط:

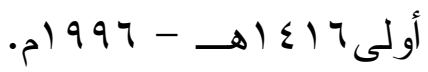

* بيان المعاني. لــ/ عبد القادر بن ملاَّ حويش السيد محمــود آل غـــازي

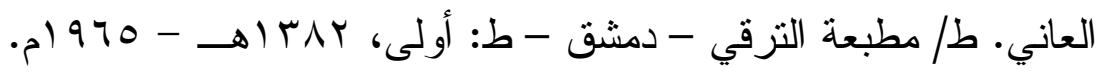
* تأويلات أهل السنة (تفسير الماتريدي) لأبي منصور الماتريدي. ط/ دار

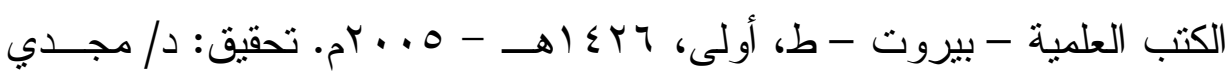
باسلوم.

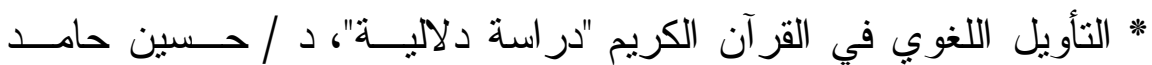
الصالح - دار ابن حزم - صنعاء بدون. * التحبير شرح التحرير في أصول الفقه.لــ/ علاء الدين أبي الحسن علي

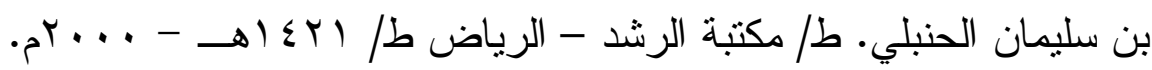

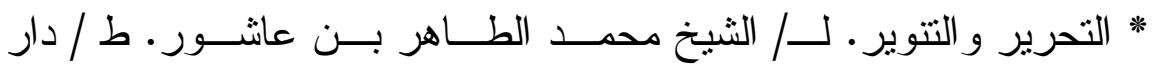
سحنون - تونس - $99 V$

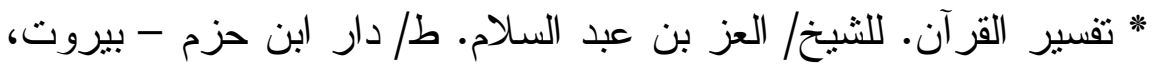

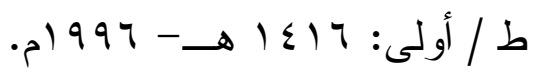

* تقسير الر اغب الأصفهاني. طل كلية الآداب - جامعة طنطا، ط - أولى:

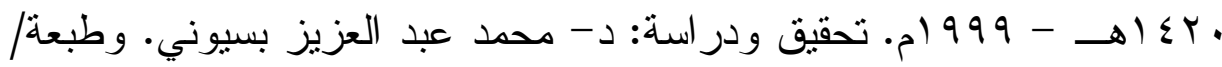

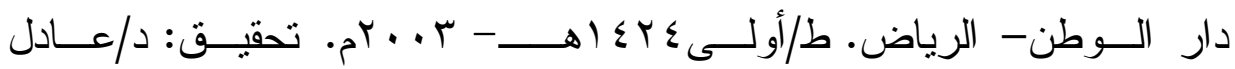
بن علي الثِّدِي. 
* تقسير الإمام المر اغــي. ط - مــصطفى البــابي الحلبـي. ط/ أولــى، . $9 \leq 7-\rightarrow 1170$

* تفسير القرآن الكريم. للإمام الثيخ / محمود شلتوت. ط - دار الثروق،

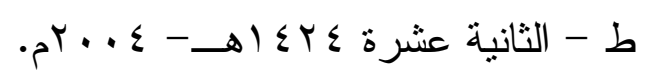

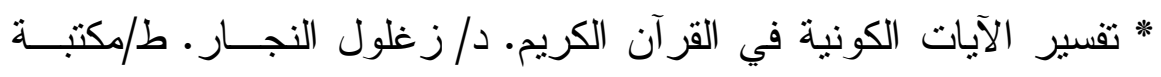

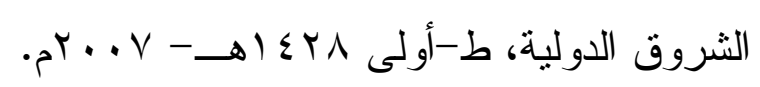

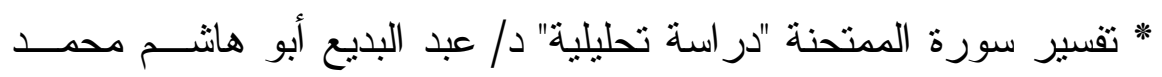

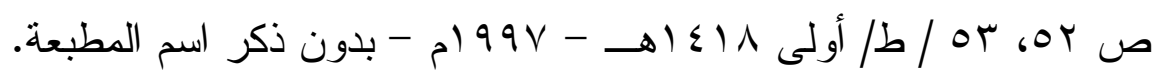
* التفسير الوسيط للقرآن الكريم. د: محمد سيد طنطاوي. ط: دار نهـــة آهـ

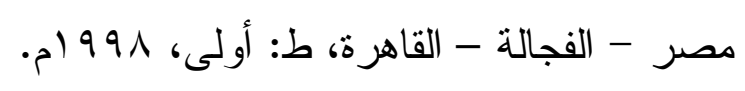

* التفسير القر آني للقر آن. د - عبد الكريم يونس الخطيب. ط / دار الفكــر

$$
\text { العربي - القاهرة. }
$$

* التفسير التحليلي لسورة النساء لــ/ أ. دـ إبر اهيم عبد الرحمن خليفــة.

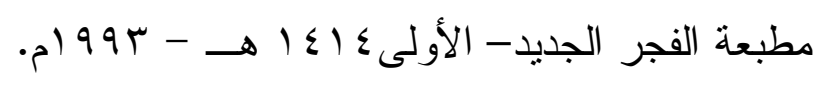

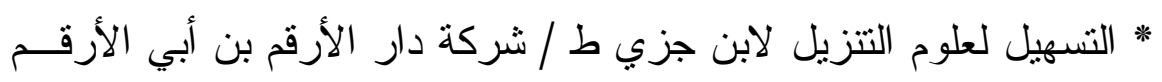

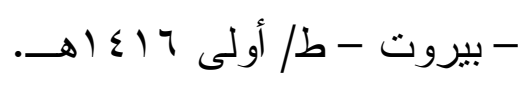

* التقرير و التحبير • لــ/ ابن أمير حاج. ط: دار الكتب العلمية - بيــروت

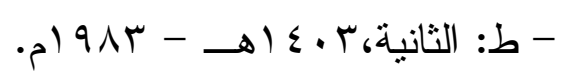

* جامع البيان في تفسير القرآن للإمام الطبري. طا مؤسسة الرســالة، ط/

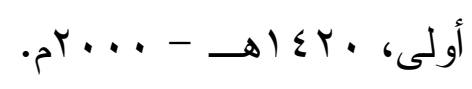

* الجامع لأحكام القرآن (تفسير القرطبي) ط - دار عالم الكتب - الرياض

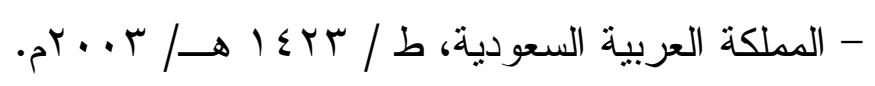




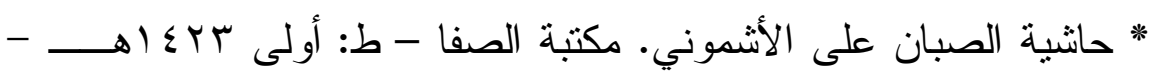
$\cdot r^{0} \cdot r$ * حاثية الخضري على ابن عقيل. ط - الحلبي.

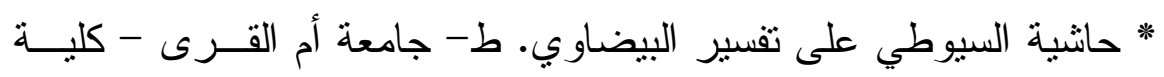

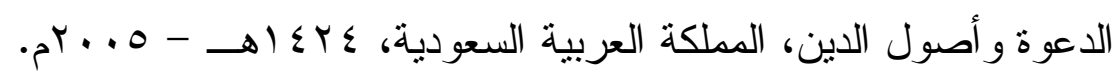

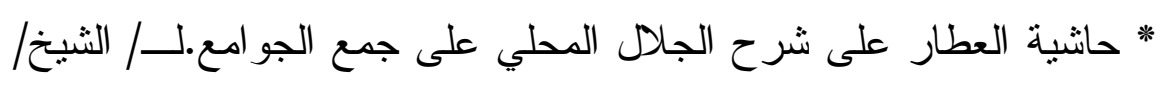
حسن العطار . الناشر : دار الكتب العلمية - بيروت.

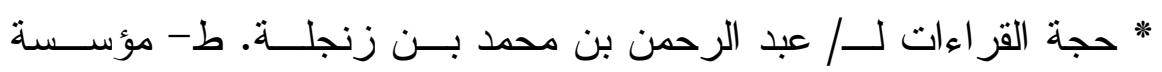

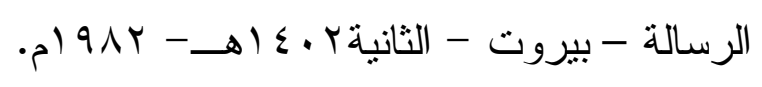
* الحلل في شرح أبيات الجمل. لــ/ عبد الله بن محمد البطليوسي.طا دار

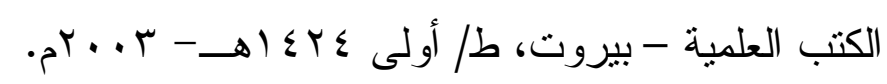

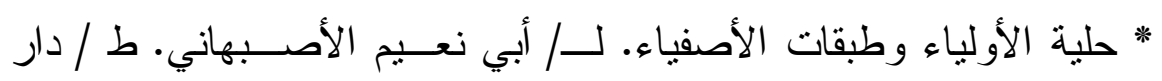
الكتاب العربي - بيروت. * خزانة الأدب. لــ/ عبد القادر عمر البغدادي. ط - دار الكتب العلمية بيروت. * خصائص التعبير القر آني وسماته البلاغية. لــ / د. عبد العظيم إير اهيم محمد المطعني. مكتبة وهبة - القاهرة، الطبعة الأولى ساعـ الهـ - 999 ام. * الدر المنتور في التفسير بالمأثور ـ للإمام / السيوطي. ط - دار الفكر - مانه بيروت. * روح البيان. لــ/ إسماعيل حقي. ط / دار الفكر - بيروت. * روح المعاني في تفسير القر آن العظيم و السبع المثاني للإمــام الألوسـيـي

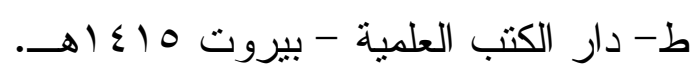


* الرسالة. للإمام الثافعي ط/ مكتبـــه الحلبـي - مـــر - ط: أولـىى،

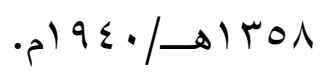

* الز هد و الرقائق. لابن المبارك.طا دار الكتب العلمية - بيــروت، و ابــن

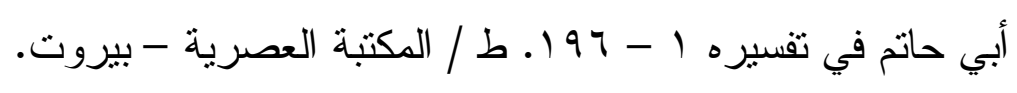

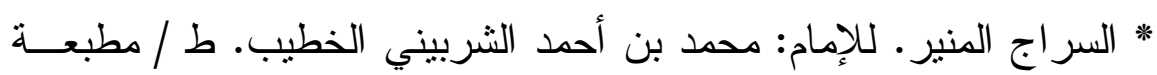

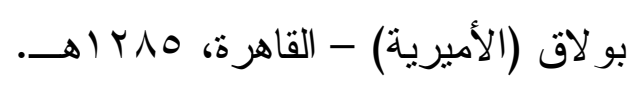

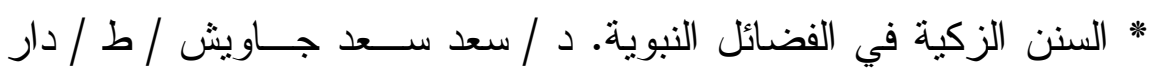

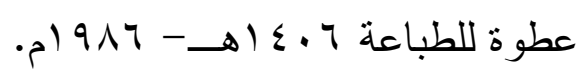

* شرح قطر الندى وبل الصدى. لابن هشام الأنــصاري، ومعــه ســبيل

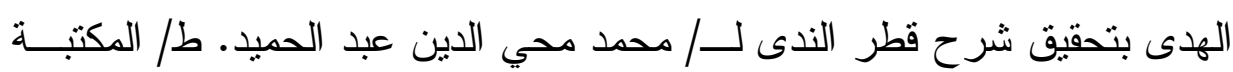

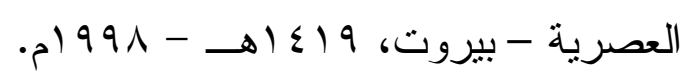

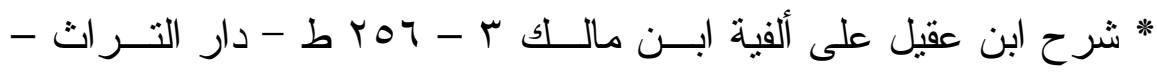

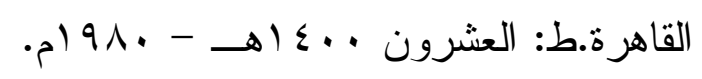

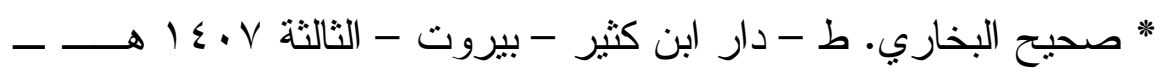

$$
\text { . } 91 \mathrm{~V}
$$

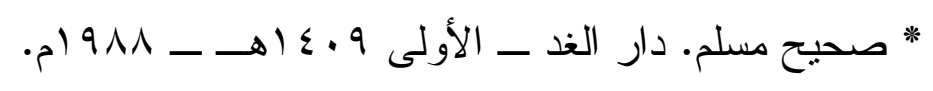

* عناية القاضي وكفاية الر اضي على تقسير البيضاوي. لــ/ شهاب الــدين

$$
\text { الخفاجي. طا دار صادر - بيروت. }
$$

* غر ائب القر آن ور غائب الفرقان. للإمام/الحسن بن محمـــــــن حسـين

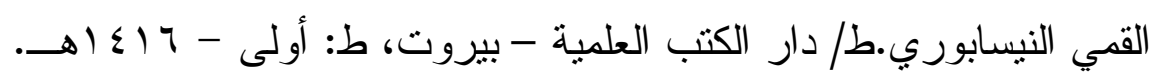

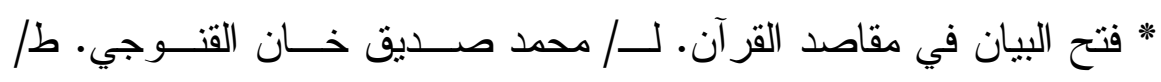

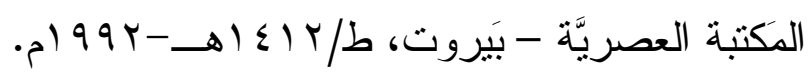


* فتح الخبير في أدو ات التقبير لــ - أ. د - سيد مرسي إبــر اهيم - ط |

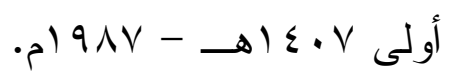

* فتح الرحمن بكثف ما يلتبس في القرآن. للإمام / زكريا الأنصاري، ط/

$$
\text { دار القر آن الكريم، بيروت - لبنان. }
$$

* فتح القدير • للإمام / محمد بن علي الثوكاني ط: دار ابن كثير، بيــروت

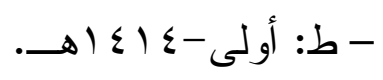

* الفواتح الإلهية و المفاتح الغيبية الموضحة للكلم القرآنية و الحكم الفرقانية.

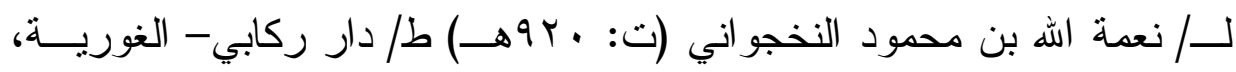

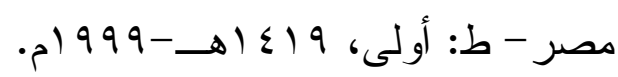

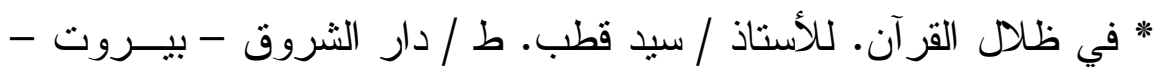

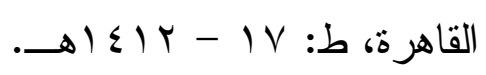

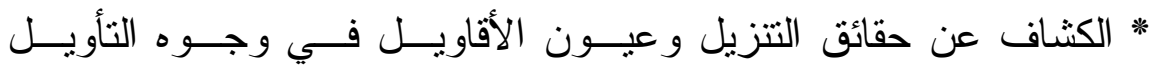

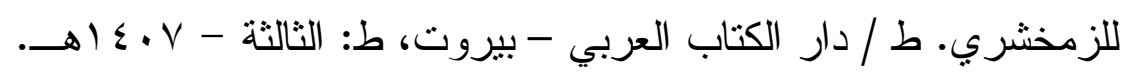

* لباب التأويل في معاني التنزيل. للإمام الخازن. ط: دار الكتب العلمية -

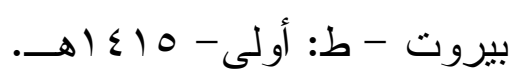

* لباب النقول في أسباب النزول. للإمام السيوطي ط/ دار الكتب العلميــة

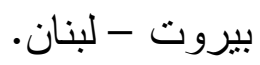

* اللباب في علوم الكتاب. لابن عادل الحنبلي. ط/ دار الكتب العلميـة -

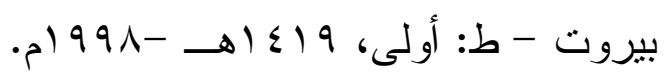

* محاسن التأويل "تفسير القاسمي". طا دار الكتب العلميه - بيروت - ط:

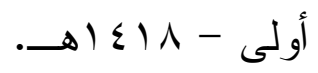


* المحرر الوجيز ـ للإمام / ابن عطية الأندلسي ط: دار الكتب العلميــة -

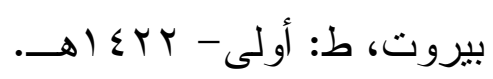
* مختصر المعاني. لــ / للعلامة التفتاز اني. ط- دار الفكـر - ط: أولـى ه $1 \leqslant 11$

* مدارك النتزيل وحقائق التأويل"تفسير النسفي"ط- دار الكتب العلميــة -

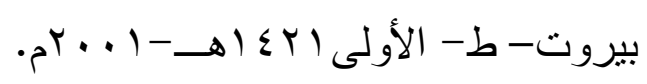

* المطول للعلامة التفتاز اني. ط - دار الكتب العلمية - بيروت.

* معالم التنزيل في تفسير القرآن ـ للإِمام البغــوي. طا دار طيبــة - ط:

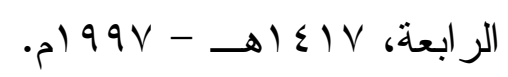

* معاني القر اءات. لــ/ محمد بن أحمد الأزهري، ط- دار الكتب العلمية-

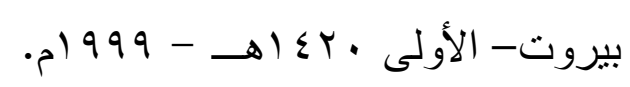

* معاني التز اكيب د/ عبد الفتاح لاتثين. ط / دار الطباعة المحمدية، بدون

تاريخ.

* مغني اللبيب. لــ/ ابــن هـشام. طـ - المكتبـــة العـصرية - بيـروت

$$
\text { . ) } 9 \wedge v-\rightarrow \Sigma \cdot v
$$

* مفتاح العلوم ـ للسكاكي. ط/ دار الكتب العلمية، بيروت - لبنــان - ط:

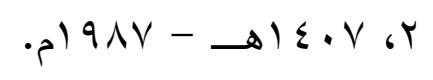

* مفاتيح الغيب للإمام الرازي. ط - دار إحياء التزاث العربي - بيــروت

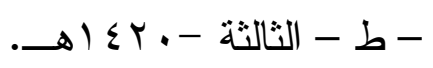

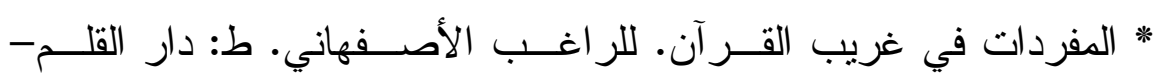

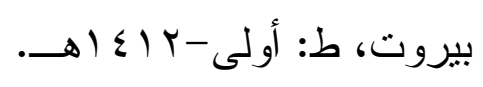


* من أسر ار التعبير القر آني "در اسة تحليلية لسورة الأحز اب". د / محمــــ

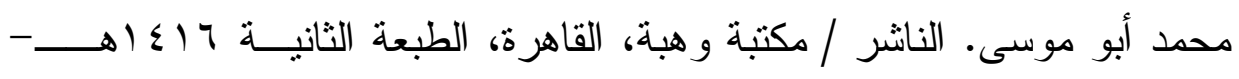
. $) 997$

* المو افقات في أصول الفقه. للإِمام الــشاطبي دار المعرفــة - بيــروت. تحقيق / عبد الله دراز •

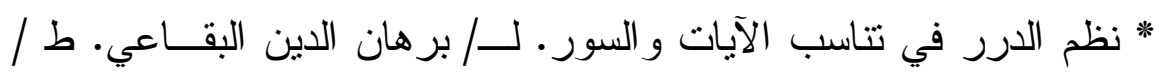
دار الكتب العلمية - بيروت - 0 إ أهـ - 990 ام.

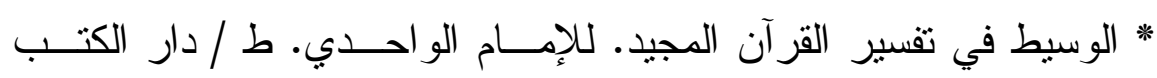

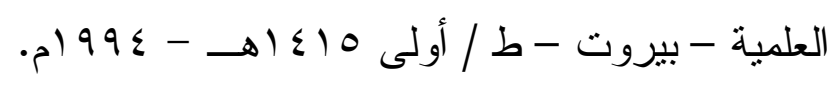

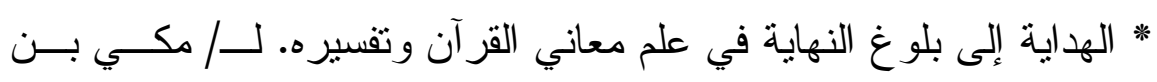

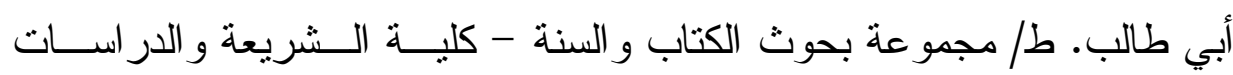

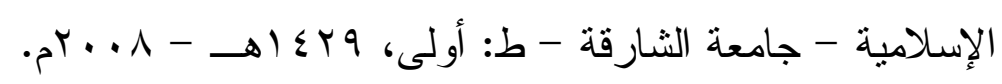


الفهرس الموضوعات

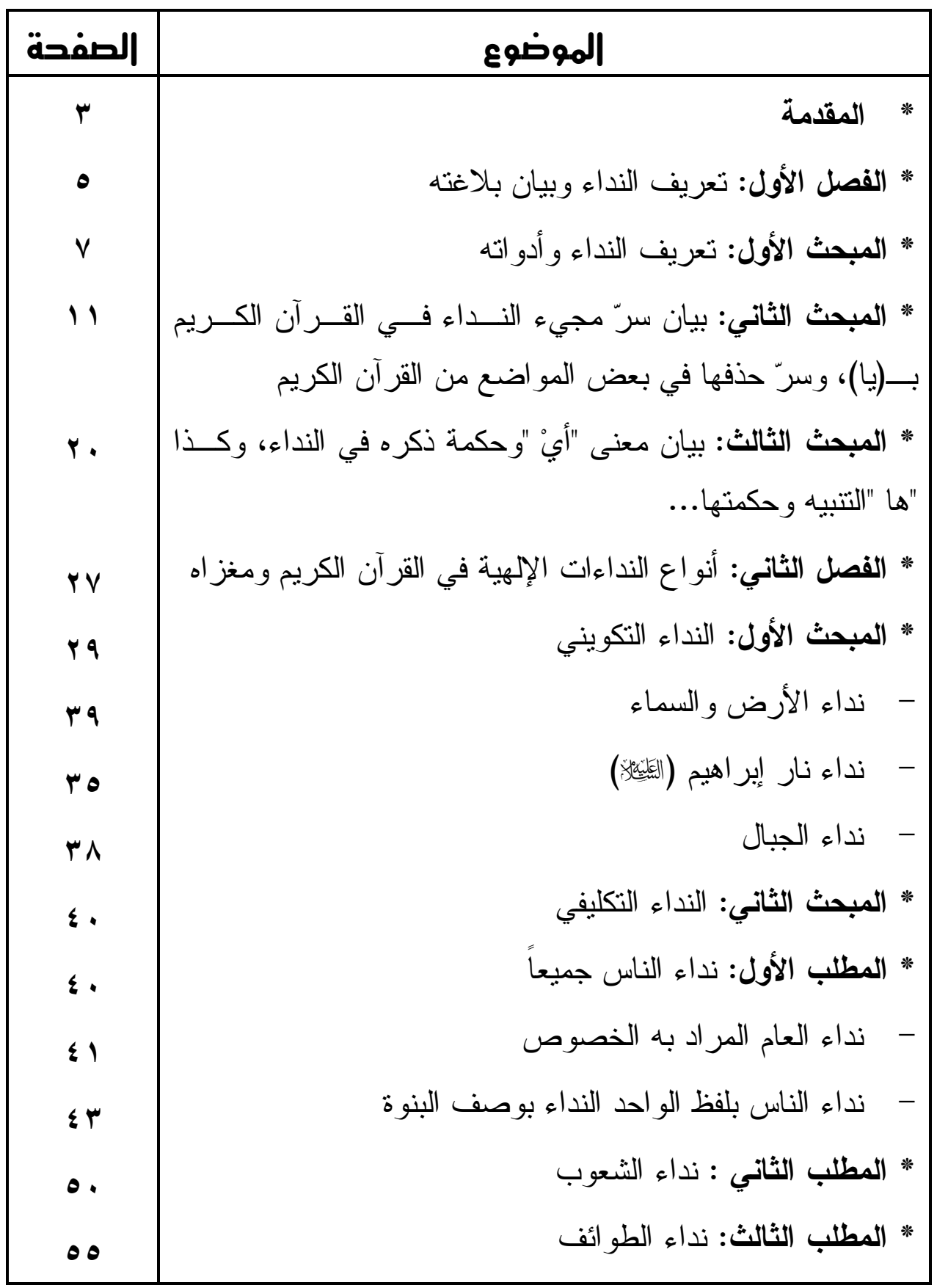




\section{الدكتور / خالد سعيد أحمد البسيوني}

\begin{tabular}{|c|c|}
\hline 00 & - نداء طائفة اليهود و النصارى \\
\hline$\Delta \wedge$ & - - نداء طائفة المؤمنين \\
\hline 91 & 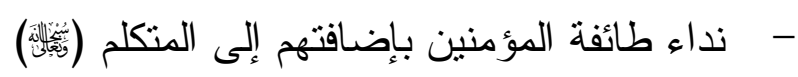 \\
\hline $7 r$ & - - نداء طائفة المؤمنين بوصف (أولي الألباب) \\
\hline $7 \varepsilon$ & 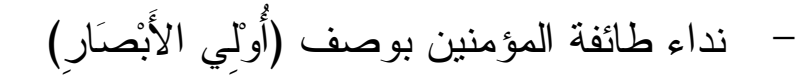 \\
\hline 70 & - - نداء أنفس المؤمنين الزكية \\
\hline 97 & المطلب الر ابع: نداء الجماعة المحدودة العدد \\
\hline 79 & المطلب الخامس: نداء الأفر اد أو الأشخاص \\
\hline 79 & - - النداء بالصفة \\
\hline vi & 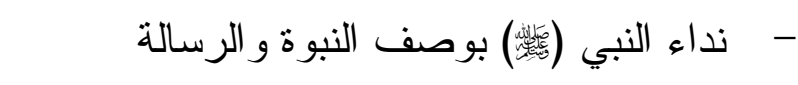 \\
\hline Vr & - - داء الشخص بحالة صـار إلبها \\
\hline$\wedge 1$ & - أهم المر اجع \\
\hline$\wedge 9$ & - هرس الموضو عات \\
\hline
\end{tabular}

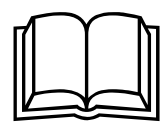

